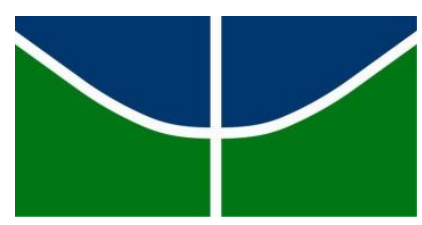

UNIVERSIDADE DE BRASÍLIA

INSTITUTO DE PSICOLOGIA

Programa de Pós-Graduação em Processos de Desenvolvimento e Saúde

“BRINCANTE É UM ESTADO DE GRAÇA": SENTIDOS DO BRINCAR NA CULTURA POPULAR

ANDRESSA URTIGA MOREIRA

Brasília, agosto de 2015. 


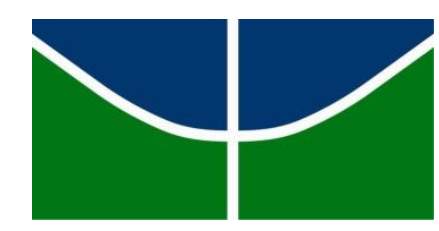

UNIVERSIDADE DE BRASÍLIA

INSTITUTO DE PSICOLOGIA

Programa de Pós-Graduação em Processos de Desenvolvimento e Saúde

\title{
"BRINCANTE É UM ESTADO DE GRAÇA": SENTIDOS DO BRINCAR NA CULTURA POPULAR
}

\author{
ANDRESSA URTIGA MOREIRA
}

Dissertação apresentada ao Instituto de Psicologia da Universidade de Brasília como requisito parcial à obtenção do título de Mestre em Processos de Desenvolvimento Humano e Saúde, na área de Desenvolvimento Humano e Cultura.

ORIENTADORA: Prof ${ }^{\mathrm{a}}$. Dr ${ }^{\mathrm{a}}$. Daniele Nunes Henrique Silva

Brasília, agosto de 2015. 


\title{
UNIVERSIDADE DE BRASÍLIA \\ INSTITUTO DE PSICOLOGIA
}

\section{DISSERTAÇÃO DE MESTRADO APROVADA PELA SEGUINTE BANCA EXAMINADORA:}

Prof $^{a}$ Dr $^{a}$ Daniele Nunes Henrique Silva - Presidente

Universidade de Brasília
Prof $^{a}$ Dr $^{a}$ Lavínia Lopes Salomão Magiolino - Membro Universidade Estadual de Campinas

Prof $^{\mathrm{a}}$ Dr $^{\mathrm{a}}$ Lúcia Helena Cavasin Zabotto Pulino - Membro

Universidade de Brasília

\author{
Prof $^{\mathrm{a}} \mathrm{Dr}^{\mathrm{o}}$ Jorge das Graças Veloso - Suplente \\ Universidade de Brasília
}

Brasília, agosto de 2015. 
"Brincar é alegria! Se você estiver com o coração puro, livre, você brinca! Mas, se estiver amarrado... ai não tem graça não!"

(Tia Maria do Jongo)

"Brincar é usar o fio inteiro de cada ser. Quando você está usando seu fio inteiro de vida, você está brincando! E é profundamente sério isso."

(Maria Amélia Pereira) 
Dedico esta dissertação aos mestres e às mestras brincantes que me ensinam a usar meu fio inteiro de vida, em tempos de profundos cortes. Em especial ao mestre Zé do Pife, à mestra Martinha do Coco e ao grupo Seu Estrelo e o Fuá do Terreiro, com profunda gratidão. 


\section{AGRADECIMENTOS}

Ao meu marido, Filipe Braga, pelo amor, parceria e estímulo nessa caminhada de vida.

Ao meu pai Rui e à minha mãe Fátima, pelo apoio e cuidado. À minha vó Luzia, mestra de longas jornadas e, também, ao meu irmão Assis, pelo carinho e companhia. Ao meu sogro Pedro e à minha sogra Lúcia, pelos estímulos preciosos.

À minha orientadora Daniele, por acreditar, incentivar e compor junto esta pesquisa, com a firmeza de uma professora e a delicadeza de uma amiga. Além disso, por me ensinar a trabalhar verdadeiramente em equipe.

Aos/às amigos/as integrantes do grupo Seu Estrelo e o Fuá do Terreiro, que participaram e apoiaram esta pesquisa: Tico, Luciana, Luís Felipe, Daniele N., Danielle F., Sarah e Camila.

Ao grupo Diá(logos) em Psicologia, pelo incentivo e pelas colaborações essenciais a este trabalho. Em especial aos/às amigos Fabrício Abreu, Marina Costa, Angélica da Silva e Eva Cruz, pelas trocas e auxílios que tornaram essa caminhada ainda mais gratificante.

Aos/às professores/as da UnB, Maria Luiza Pereira, Graça Veloso e Nelson Inocêncio que, ainda em meus tempos de graduanda, plantaram as sementes desta pesquisa com seus fervorosos debates sobre cultura e educação popular.

Aos/às meus/minhas colegas de profissão, arte-educadores/as e artistas, que seguem com "a estranha mania de ter fé na vida", em especial às amigas Mônica Kanegae, Semíramis de Medeiros, Isabela Ribeiro, Maíra Machado e Cristiane Coelho.

Ao psicólogo Carlos Maltz, pelos acolhimentos e incentivos valiosos.

Ao Davi Carvalho, à Keila Vila, à Ana Terra e à Raquel Capucci, pelos apoios incalculáveis com as imagens, transcrição dos dados, revisão e tradução.

Aos/às colegas professores e estudantes do Centro de Ensino Fundamental Dr ${ }^{\mathrm{a}}$ Zilda Arns, pelas lutas e conquistas de cada dia. 


\section{RESUMO}

Historicamente, a psicologia do desenvolvimento tem privilegiado o brincar na infância, contudo, acreditamos que brincar é uma necessidade ontológica que se estende ao longo de toda a vida. Assim, nesta pesquisa, focalizamos a brincadeira no contexto da cultura e arte popular, tendo como recorte sujeitos adultos que se autodenominam brincantes. Por essa via, investigamos a produção de sentidos na e da constituição dos/as brincantes à luz da psicologia histórico-cultural. Refletimos, então, sobre a experiência estética com ênfase na psicologia da arte, proposta por Lev Vigotski, e sua relação com o brincar e a psicologia do drama. Recorremos também aos estudos de Mikhail Bakhtin, investigando o brincar, no contexto da cultura popular, como uma atividade situada no entrever entre arte e vida. Metodologicamente, optamos pela narrativa como uma indicadora qualitativa que auxilia na abordagem dos processos de constituição de subjetividades. Realizamos a pesquisa de campo com os/as brincantes do grupo Seu Estrelo e o Fuá do Terreiro, que desenvolvem uma brincadeira denominada teatro de terreiro. Essa etapa ocorreu na sede do grupo, localizada em Brasília (DF), ao longo de dois períodos: a) imersão da pesquisadora no campo e acompanhamento dos ensaios, durante $\mathrm{o} 1^{\circ}$ semestre de 2013; e b) entrevistas narrativas, realizadas no $2^{\circ}$ semestre de 2014. Utilizamos como instrumentos o diário de campo e a videogravação das entrevistas. Discutimos os dados com base na análise do discurso, que enfatiza a dimensão socioideológica das narrativas - por se tratarem de material semiótico. A análise foi dividida em três eixos: a) da criança que brinca ao ofício de brincante: transformações de sentidos do brincar; b) a relação entre tradição e inovação na constituição dos brinquedos e das brincadeiras; e c) trabalho e luta: políticas de resistência pelo encantar. Ademais, indicamos na discussão dos dados que a produção de sentidos na/da constituição dos/as brincantes apontam para múltiplos aspectos como: o sentido da resistência, da comunhão, do reconhecimento histórico, profissional e de si mesmo, dentre outros. Ao final, enfatizamos a necessidade política de reconfiguração das noções ainda vigentes sobre o brincar, a partir de um olhar mais sensível às expressões populares e que se fundamenta na dimensão ontológica do termo. Pelo brincar, produzimos sentidos que emancipam a nossa experiência, que nos humanizam. Da criança ao mais idoso dos sujeitos é urgente nos fazermos e sermos mais brincantes.

Palavras-chave: histórico-cultural, psicologia da arte, sentido, brincar e cultura popular. 


\begin{abstract}
Historically, Developmental Psychology has emphasized the play in childhood; however, we believe that playing is an ontological activity that extends throughout life. Therefore, in this research we focused on playing of adults, who call themselves brincantes (players), in the context of folk art. We investigated the construction of meaning and the constitution of players in the historical-cultural psychology perspective. We discussed, then, about the aesthetic experience with emphasis on psychology of art, proposed by Lev Vygotsky, and its relationship with the play and psychology as drama. Also appealed to the studies of Mikhail Bakhtin and, in this way, we discussed about the play in the context of popular culture as an activity in the glimpse between art and life. Moreover, we question the concept of popular culture, emphasizing its political dimension in Paulo Freire, and aesthetics in Mikhail Bakhtin. Methodologically, we chose the narrative as a qualitative indicator that assists in addressing the constitution of subjectivity processes. The field study was conducted with the group of players called Seu Estrelo e o Fuá Terreiro, developing a game called yard theater. This study took place at the group's headquarters, located in Brasília (DF), over two stages: a) immersion of the researcher in the field and monitoring of trials during the 1st half of 2013; b) narrative interviews conducted in the 2nd half of 2014. The instruments used were the diary and video recording of interviews. We discussed data based on the analysis of discourse that emphasizes the social-ideological dimension of narrative, since they are semiotic material. The analysis was divided in three axes: a) the child who plays to the art of the player: transformation of meanings of play; b) the relationship between tradition and innovation in the creation of toys and playing; c) work and struggle: resistance by the art of enchant. We indicated in the discussion of data that the construction of meaning in/of the constitution of players points to multiple aspects such as: the meaning of resistance, of communion, history, professional and self-recognition, among others. Finally, we emphasized the political necessity of reconfigurating of still prevailing notions of play, from a more sensitive vision, based on the ontological dimension of the term, to popular expressions. Senses that emancipate experiences that humanizes us are built through playing. From children to the elder, it is urgent to provide opportunity for us to live as players, due to its importance for our development and constitution as human beings.
\end{abstract}

Keywords: historical-cultural perspective, psychology of art, meaning, playmk, and popular culture. 


\section{SUMÁRIO}

$\begin{array}{lr}\text { Apresentação } & 12\end{array}$

1 Psicologia Histórico-Cultural 19

$\begin{array}{ll}1.1 O \text { princípio da dialética } & 19\end{array}$

1.2 Psicologia concreta: influências do materialismo histórico e dialético 21

1.3 Conceitos norteadores da perspectiva histórico-cultural $\quad \mathbf{2 4}$

$1.4 \mathrm{O}$ sentido em Vigotski: linguagem e experiência estética 31

2 Experiência Estética 35

2.1 Arte, criação e imaginação 36

$\begin{array}{ll}2.2 \text { Imaginação e criação como exceção } & 37\end{array}$

2.3 Imaginação e criação como regra 39

2.4 Catarse: psicologia da arte $\mathbf{4 5}$

3 O Brincar $\quad 54$

$3.1 \mathrm{Os} /$ As brincantes da cultura popular $\quad \mathbf{5 9}$

3.2 Cultura popular: rediscutindo o conceito $\quad 60$

3.2.1 Brincadeiras: resistência e luta 64

3.2.2 Brincadeiras e festejos populares: contribuições de Mikhail Bakhtin 69

$\begin{array}{ll}3.3 \text { Delimitação do estudo: psicologia da arte e cultura popular } & \mathbf{7 4}\end{array}$

$\begin{array}{lll}3.3 .1 & \text { Objetivos } & 76\end{array}$

4 Metodologia $\quad \mathbf{7 7}$

$\begin{array}{ll}\text { 4.1 Comunicação e investigação narrativa } & 77\end{array}$

4.2 A entrevista narrativa como construção de dados

4.3 Especificidades de uma pesquisa de fronteira (psicologia da/e arte) $\quad 82$

4.3.1 Características do campo e do grupo participante 83

4.3.2 Breve histórico do grupo participante 86

4.3.2.1 As figuras encantadas: uma licença poética para a imaginação 90

4.4 Narrativas: construção dos dados e perfil dos/as participantes 93

$\begin{array}{ll}4.5 \text { Procedimentos para análise de dados } & 95\end{array}$

5 Apresentação e Discussão dos Dados 97

5.1 Eixo A) Da criança que brinca ao ofício de brincante 97

5.2 Eixo B) A relação entre tradição e inovação nas brincadeiras populares 121 
5.2.1 A figura e o corpo: rituais no/do fazer-ser brincante

5.2.2 O brincar no teatro de terreiro: a tradição como invenção

5.3 Eixo C) Trabalho e luta: políticas de resistência pelo encantar

Reflexões Finais

Referências

Anexos

Anexo 1 - O Mito do Calango Voador

176

Anexo 2 - Parecer Consubstanciado do Comitê de Ética

187 


\section{LISTA DE IMAGENS}

Figura 1 - Seu Estrelo e o Fuá do Terreiro

Figura 2 - A Orquestra Alada Trovão da Mata

Figura 3 - Capas das produções literárias do grupo

Figura 4 - Placa da sede do grupo, na 813 Sul

Figura 5 - Placa da Vila Cultural

Figura 6 - Seu Estrelo em matéria de jornal

Figura 7 - Seu Estrelo em programa de rádio

Figura 8 - Seu Estrelo, terceira roda (Funarte, 2013)

Figura 9 - Maracatu rural

Figura 10 - Cavalo marinho

Figura 11 - Roda marcada a giz no Beco Cultural

Figura 12- Dani N. botando a Véia Tiroiá e Lipe como Capitão

Figura 13 - Tico botando a Véia Tiroia

Figura 14 - Folder digital de divulgação da brincadeira

Figura 15 - Capa do CD do Seu Estrelo (2009)

Figura 16 - Seu Estrelo, terceira roda (Funarte, 2013)

Figura 17 - Laiá, terceira roda (Funarte, 2013)

Figura 18 - Capitão Sebastião, terceira roda (Funarte, 2013)

Figura 19 - Calango Voador, terceira roda (Funarte, 2013)

Figura 20 - Roda de giz desenhada no Beco Cultural

Figura 21 - Roda pintada na casinha

Figura 22 - Discussão da ordem das figuras

Figura 23 - Detalhe das anotações 


\section{APRESENTAÇÃO}

As principais questões desta pesquisa surgiram durante a minha formação como artista e arte-educadora no curso de artes plásticas, na Universidade de Brasília (UnB), a partir de 2005. Foi em meio aos diversos debates acadêmicos que o tema do/a artista popular emergiu. Isso porque, talvez já naquela época, era nessa dimensão - de artista e educadora popular - que eu gostaria de me ver atuando no futuro.

Entretanto, é bastante complexo pensar que em um espaço acadêmico (considerado, por vezes, erudito) poderia me formar artista (popular). Visto, inclusive, que uma das definições que envolvem a noção de cultura popular - da qual emerge a de artista popular - fundamenta-se em uma relativa independência de vínculo com as instituições oficiais do Estado (Carvalho, 2005); logo, com o que também está vinculado à academia. Desse modo, ainda parece contraditório imaginar artistas populares da (e na) universidade.

Figura 1 - Seu Estrelo e o Fuá do Terreiro, no VIII

Mas, paradoxalmente, foram os Encontro de Culturas Tradicionais das Chapadas dos Veadeiros, em 2010

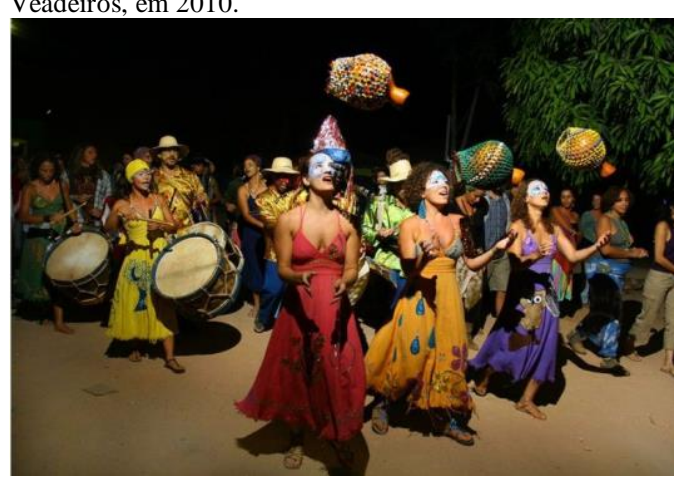

Foto: Retirada da internet pelo site: http://www.encontrodeculturas.com.br/2010/galeriaDetalhe.php?alb um=62\& grupo $=55$ [acessado em novembro de 2012]. espaços acadêmicos que me proporcionaram experiências marcantes como: aprender a fazer e a tocar pífano, participar de oficina sobre a Ação Griô e a preservação das tradições orais, dançar toré com estudantes indígenas no pátio da Faculdade de Educação, dentre outras ${ }^{1}$. Assim, foi em meio a essas vivências universitárias que, no ano de 2008 , avistei pela primeira vez o

\footnotetext{
${ }^{1}$ Essas atividades - que tornavam o acadêmico mais 'popular' e vice-versa -, dentro do contexto maior da UnB, ainda eram pontuais e atingiam grupos pequenos, se comparados ao número total de estudantes do período.
} 
grupo Seu Estrelo e o Fuá do Terreiro. Na ocasião, o Seu Estrelo, como é mais conhecido, realizava um cortejo pela UnB para divulgar o IV Festival Brasília de Cultura Popular - organizado pelo próprio grupo. Com roupas coloridas, rostos pintados, alfaias, agbês, etc., batuqueiros/as e dançarinos/as do grupo chamavam a atenção por onde passavam.

Pelo interesse gerado, participei do festival e, em 2009 , Figura 2 - A Orquestra Alada Trovão da Mata no Espaço Imaginário Cultural, em Sobradinho-DF (2013).

comecei a frequentar semanalmente os ensaios abertos que o Seu Estrelo oferecia. Esses ensaios, a partir de 2012, geraram um grupo de percussão à parte, chamado Orquestra Alada Trovão da Mata o qual eu integro até o atual

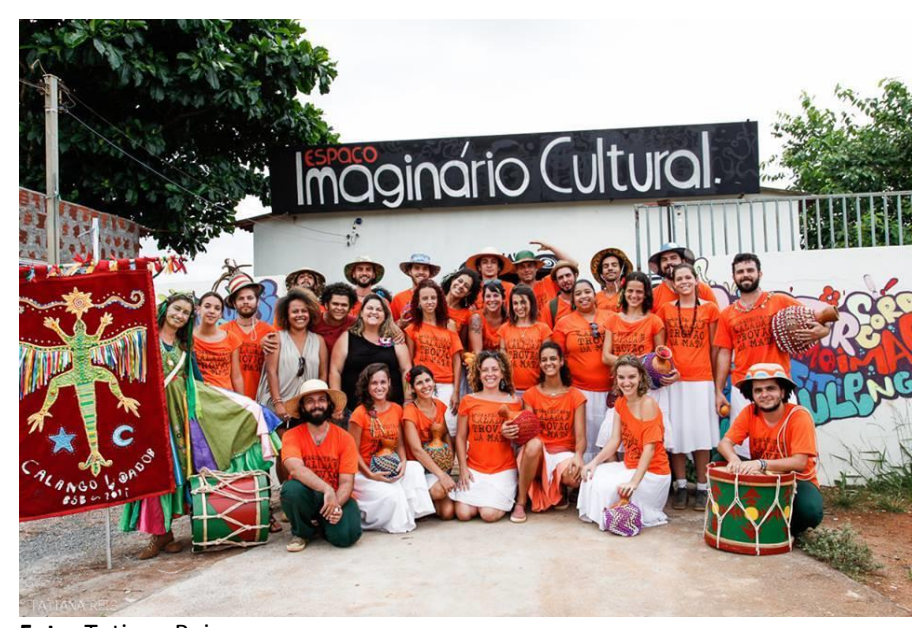
momento. Essa integração me mantém, desde então, em contato continuo com os/as participantes do Seu Estrelo, pois, muitos deles/as também participam da Orquestra. Atualmente, inclusive, a Orquestra ensaia na sede do grupo, denominada Centro Tradicional de Invenção Cultural.

Nessa trajetória, é importante enfatizar que conhecer o Seu Estrelo foi um demarcador de significativas mudanças em minha vida, que me possibilitou/possibilita aprendizados e parcerias valiosas, dentro do uni(di)verso das manifestações populares. Foi, por exemplo, por intermédio do grupo que estabeleci contatos e amizades com inúmeros artistas e grupos populares que fazem parte da cena cultural do Distrito Federal e de outras regiões do país, como: o Boi do Seu Teodoro (de Sobradinho), o Tamnoá e a mestra Martinha do Coco (do Paranoá), o Invenção Brasileira (de 
Taguatinga), o grupo de maracatu Piaba de Ouro (de Olinda), o Jongo da Serrinha (do Rio de Janeiro) etc.

Assim, o Seu Estrelo me proporcionou/proporciona aprendizados não apenas técnicos - como tocar um instrumento, realizar uma determinada dança ou um tipo específico de bordado — mas, ele foi/é um abridor de incalculáveis portas, espaços, relações, trocas, que me aproximam, cada vez mais, da pessoa (artista-educadorapopular) que eu, ainda nos tempos de graduanda, desejava me transformar. Caminho de transformação, por sua vez, repleto de desejos realizados, mas que também vem sendo moldado pelas inúmeras batalhas e dificuldades cotidianas; encontradas por aqueles/as que se aventuram a percorrer as trilhas, ainda periféricas, da cultura popular brasileira.

Seguindo essas trilhas, há mais de onze anos, o Seu Estrelo continua desenvolvendo uma série de atividades artísticas que permeiam, sobretudo, a contação (narração) de uma história fantástica denominada $O$ Mito do Calango Voador. Para contar esse mito sobre o surgimento do mundo, do cerrado e da humanidade, o grupo possui uma série de atividades que envolvem a literatura, a música, a dança, o teatro, a elaboração de figurinos e de cenários, dentre outras.

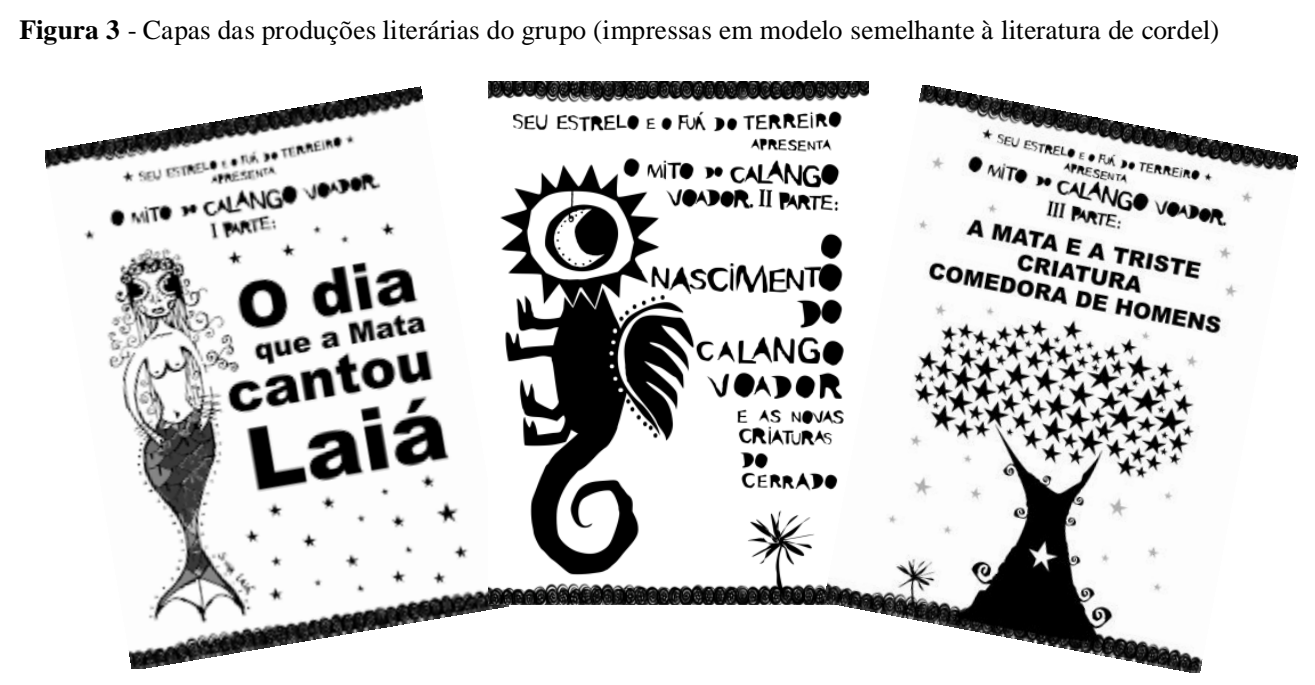

Durante as diversas participações em oficinas e mutirões com o grupo, observei que as atividades do Seu Estrelo se diferiam substancialmente das atividades propostas 
pela academia. Pois, geralmente, na universidade, os estudos dos diversos campos artísticos eram/são estruturados em formatos de cursos em que se ensina/aprende "a" $o u$ "b” (música ou artes visuais, por exemplo). Já com o Seu Estrelo, ao mesmo tempo em que bordávamos o figurino de uma personagem da peça, por exemplo, aprendíamos a cantar músicas, contávamos e a escutávamos histórias diversas (“causos”), dentre outras atividades.

Esse modo de criar do grupo, por sua vez, parece ser bastante comum aos modos de criação da cultura popular. No entanto, é também arriscado e difícil definir quais são esses modos de criações, específicos da chamada cultura popular e do seu suposto oposto, a erudita. O Seu Estrelo, assim como muitos outros grupos da cidade Chinelo de Couro, Mestre Zé do Pife e as Juvelinas, Pé de Cerrado -, parecem ocupar uma ponte entre ambas as definições. Seus integrantes são, por exemplo, em sua maioria, adultos que já finalizaram um curso superior e que compõem, então, um grupo de artistas populares com bases também acadêmicas que, na realidade, se autodenominam de brincantes. Assim, questiono: é um grupo de cultura popular? Não é um grupo de cultura popular? O que é cultura popular?

Aqui, não posso negligenciar que essa última indagação é historicamente discutida por inúmeros outros pesquisadores (como Arantes, 2006; Brandão, 2011; Chartier, 1995) e que, inclusive, atualmente existem alguns apontamentos que indicam o seu desuso - sugerindo outras terminologias como apenas culturas, no plural e sem demais adjetivações (Veloso, 2011) ou trocas de saberes (Carvalho, comunicação pessoal, julho de 2010). Porém, o termo cultura popular ${ }^{2}$ integra as expressões do

\footnotetext{
${ }^{2}$ É importante enfatizar que o conceito de cultura popular é problematizado e que sua utilização nesta pesquisa se dá por dois pontos fundamentais: a) pela apropriação do conceito pelos/as próprios/as brincantes pesquisados/as, já que proponho realizar um trabalho em parceria com esses sujeitos, considerando, assim, as terminologias utilizadas por eles/as em relação às suas práticas; e b) Por acreditar ser um demarcador político ainda necessário à academia, que evidencia as lacunas ou exclusões sociais que outras categorias como "culturas" omitem nesse contexto. Assim, a utilização do termo "cultura
} 
grupo em questão a partir de uma lógica conceitual peculiar. Assim, achamos válido utilizá-lo, mas, ressaltamos, por outra via de significações, que será cuidadosamente traçada ao longo desta pesquisa.

Desse modo, veremos que a apropriação desse conceito envolve condições específicas de atuar no mundo e que, de forma ampla, historicamente a cultura popular foi, e continua sendo, situada à margem da sociedade. Nesse contexto, ser brincante não é uma escolha que promove um amplo reconhecimento social, mas ao contrário, é um caminho tempestuoso, de nados contracorrente.

Por essa via, nesta pesquisa questiono: o que leva esses/as inúmeros/as brincantes da cultura popular a optarem por essa escolha de vida, socialmente desprestigiada? Possivelmente, deve haver algo bastante valioso que supera as barreiras enfrentadas há tempos; algo que nutre de sentidos suas vidas de brincantes. Mas, o que é brincar no contexto da cultura popular? Afinal, quais são as produções de sentidos da/na constituição dos/as brincantes?

Considero, inicialmente, que esse/a brincante adulto é, também, o que tem sido denominado por artista popular. Assim, para responder tais inquietações foi necessário adentrar nas estruturas basilares da arte e buscar entendê-la em seus mecanismos psíquicos, nas matrizes que impulsionam o ser humano a criar e a experienciar a arte em quaisquer tempos, espaços e culturas. Nesse intuito recorremos principalmente aos estudos em psicologia realizados por Vigotski (1999a, 1999b, 2009) sobre imaginação, criação e arte.

popular" é aqui compreendida como uma ação afirmativa que busca evidenciar as "culturas" historicamente omitidas nessa conjuntura. Exemplificando, enquanto um artista "popular" (como Zé do Pífe etc.) não possuir a "voz" ou a inserção que um artista "erudito" (como Bach etc.) possui dentro desse contexto "formal" de ensino, no Brasil, defendo a necessidade desta terminologia "popular", como demarcadora de "mudos" e de denunciação de exclusões sociais historicamente marcadas. Assim, nos aproximamos também dos Movimentos de Cultura Popular da década de 60, que explicaremos no capítulo três. 
A arte, seja nas manifestações classificadas como eruditas ou populares, é uma atividade cultural complexa, resultante e provocante do humano imaginativo e recreativo que somos. E é justamente nesse contexto mais amplo, da psicologia da arte e do desenvolvimento humano que, a partir do materialismo histórico-dialético, busco refletir sobre a produção de sentidos que constituem as subjetividades dos/as brincantes.

Para tanto, antes de focarmos a psicologia da arte, inicialmente julgo ser necessário refletir acerca de alguns princípios epistemológicos gerais da vertente histórico-cultural. Assim, no capítulo 1, discuto a noção de dialética na psicologia concreta, proposta por Vigotski e colaboradores. Nessa perspectiva, enfatizo também os conceitos de internalização, mediação semiótica e linguagem - essenciais para o entendimento dessa corrente. Pelo conceito de linguagem, introduzo uma análise sobre o sentido do sentido, em Vigotski; conceito central neste trabalho. Por fim, alcanço a noção de sentido na psicologia vigotskiana, centrada na experiência estética.

No capítulo 2, aprofundo os conceitos de imaginação, criação e arte, como dimensões fundamentais à experiência estética, em Vigotski. Além disso, também lanço mão às discussões bakhtinianas acerca da arte como ideologia e às contribuições mais recentes da sociologia da arte, que sinaliza os mecanismos sociopolíticos de sua institucionalização.

Em seguida, no capítulo 3, discorro sobre o brincar, como uma atividade essencial ao desenvolvimento humano, para pensar, adiante, na condição do/a brincante no contexto da cultura popular. Desenvolvo também uma reflexão histórica sobre o conceito de cultura popular e resgato Bakhtin, lançando uma discussão acerca das singularidades da estética popular. Por conseguinte, traço a delimitação do estudo e sinalizo sua relevância na atual conjuntura acadêmica, ressaltando os objetivos da pesquisa. 
Na discussão metodológica, no quarto capítulo, discuto sobre a narrativa como um indicador qualitativo que auxilia na abordagem dos processos de constituição de subjetividades. Em seguida, teço uma reflexão sobre ética de pesquisa e identificação dos participantes. A partir de então, justifico a escolha do grupo Seu Estrelo e o Fuá do Terreiro, no que diz respeito à realização da pesquisa de campo, e apresento um breve histórico do grupo. Ademais, reflito sobre os rumos tomados na construção e análise dos dados.

No capítulo 5, discuto os resultados do estudo com ênfase na análise de narrativas (análise de discurso), enfatizando os seguintes eixos: a) as transformações de sentidos do brincar articulada às histórias de vida dos/as brincantes; b) a relação entre tradição e inovação na constituição dos brinquedos e das brincadeiras e c) a dimensão política (resistência/luta) na atuação dos/as brincantes. Em seguida, nas reflexões finais, resgato as principais contribuições da pesquisa, relatando os seus limites e possíveis desdobramentos. 


\section{PSICOLOGIA HISTÓRICO-CULTURAL}

\subsection{O princípio da dialética}

A psicologia histórico-cultural é fundamentada em uma perspectiva dialética. Para Vigotski [1896-1934], nessa abordagem, a dialética se articula necessariamente ao sentido histórico, que, por sua vez, ultrapassa a ideia cronológica do termo história. Nessa dimensão, a dialética consiste em uma tensão entre a história natural e cultural do humano; mais precisamente, entre a história da natureza, de ordem biológica, e a história dos sentidos, estabelecida por meio das relações sociais (Vigotski, 2000).

Por essa via, as funções psicológicas superiores, que dimensionam o ser humano em uma condição/constituição diferenciada dos demais seres da natureza, são subordinadas à tensão entre esses dois processos históricos maiores. Para Luria ${ }^{3}$ [19021977], essas funções — ou motivos superiores — possuem raízes nas “condições sociais de vida historicamente formadas" (1991, p. 75).

Assim, o ser humano ultrapassa suas necessidades biológicas (história natural do animal), desenvolvendo uma estrutura de comportamento e formas de vida radicalmente distintas dos animais (história social da humanidade). Nessa perspectiva histórica e cultural do desenvolvimento psíquico, o "homem"4 projeta atividades singulares pela sua dimensão consciente (Luria, 1991). Desse modo, somos capazes de desenvolver, ao mesmo tempo, a consciência de nossa condição histórica e a consciência da nossa própria consciência (Fávero, 2005).

\footnotetext{
${ }^{3}$ Ao lado de Vigostski e Leontiev, Luria foi um dos principais teóricos que fundamentou as bases da psicologia histórico-cultural.

${ }^{4}$ A palavra "homem" será colocada entre aspas ao longo do texto para evidenciar que não se trata apenas dos homens, mas da humanidade, ou seja, homens e mulheres.
} 
Contudo, do mesmo modo que nos distanciamos substancialmente da natureza devido a essa constituição diferenciada, também estamos "radicalmente ligado(s) a ela, pelo cordão umbilical que alimenta a (nossa) realidade biológica” (Pino, 2005, p. 17). Assim, como uma via de mão dupla constantemente tensionada — de afastamentos e aproximações contínuas —, percebemos que, nessa corrente psicológica, a dimensão cultural não exclui a natural, mas a transforma.

Ainda acerca da noção dialética na abordagem histórico-cultural, percebemos que esse conceito se desdobra em sentidos que vão além da sua perspectiva histórica, desenvolvidos por Vigotski e seus colaboradores. Para Delari Junior (2011), a dimensão dialética na obra do autor bielorrusso é evidenciada também por meio de sua matriz metodológica.

Segundo esse pesquisador, Vigotski constituiu uma matriz metodológica dialética quando se propôs a estudar determinadas teorias sem refutá-las completamente, mas se apropriando de conceitos elaborados por outros pesquisadores e os redimensionando. Percebermos essa dialética, por exemplo, nos conceitos de catarse e drama, fundamentais para nossa pesquisa. Ao mesmo tempo em que utiliza essas antigas noções gregas, Vigotski as modifica (Delari Junior, 2011), transformando-as em próprios conceitos.

A dialética é, portanto, também uma perspectiva metodológica que assume a contradição (Delari Junior, 2011), de modo que a construção do conhecimento não se realiza por uma coisa ou outra, mas de uma coisa e outra (seja um conceito, uma tese, etc.). Dessa maneira, notamos que noções aparentemente opostas - como natureza e cultura, por exemplo - se coconstituem na obra do autor bielorrusso.

É interessante notar que essas noções de dialética, tanto no sentido histórico, quanto no sentido metodológico, são complementares, pois o próprio sentido histórico 
decorre de um processo metodológico. Assim, se Vigotski (2000) parte de uma noção psicológica dialética, seu modo de pesquisar e de desenvolver sua teoria torna-se coerente ao assumir esse caráter contraditório, inerente à própria pesquisa.

Outro aspecto relevante da dialética metodológica é observado nos estudos de Ferrari, Robinson e Yasnitsky (2010). Segundo esses autores, Vigotski buscou unificar o que as duas principais escolas de psicologia de sua época separavam: o idealismo, de Chelpanov, e o fisiologismo, de Pavlov. Contudo, as inúmeras contribuições de Vigotski vão além de uma simples junção entre essas duas correntes opostas, perpassando a elaboração de uma nova síntese teórica, a partir delas. Entendemos que essa síntese, por sua vez, é fundamentada, principalmente, no materialismo histórico $e$ dialético.

\subsection{Psicologia concreta: influências do materialismo histórico e dialético}

No campo das ciências sociais e da filosofia, Marx [1818-1883] propôs um método dialético de pesquisa que partisse da observação concreta/material da realidade; opondo-se, assim, ao idealismo e positivismo científico vigentes em sua época. $\mathrm{Na}$ célebre obra $O$ capital, de 1867, o pesquisador alemão afirma:

Por seu fundamento, meu método dialético não só é diferente do hegeliano, mas é também diretamente seu oposto. Para Hegel, o processo do pensamento, que ele, sob o nome de ideia, transforma até em sujeito independente, é o demiurgo do real, enquanto o real não é mais que o fenômeno externo do processo do pensamento. Para mim, vice-versa, o elemento ideal não é mais que o elemento material transferido e traduzido no cérebro dos homens. (Marx, 2011, p. 174, grifos nossos) 
Desse modo, Marx propõe um método de pesquisa que se fundamenta na observação e análise das relações sociais com base em sua concretude — as formas materiais de existência. Por essa via, o autor argumenta que o elemento ideal (toda ideologia), que justifica dadas práticas sociais, é fruto do elemento material, das relações e condições concretas.

A partir desse método — ou desse modo de investigar um dado fenômeno histórico e cultural —, o autor dá ênfase à análise do trabalho social. Essa é uma dimensão fundamental no que diz respeito à constituição das relações (concretas) especificamente humanas. Assim, para Marx,

o homem pode viver humanamente, isto é, fazer-se enquanto homem, precisamente humanizando a natureza segundo suas necessidades e suas ideias, juntamente com os outros homens. O trabalho social é antropógeno. E distingue o homem dos outros animais: com efeito, o homem pode transformar a natureza, objetivar-se nela e humanizá-la, pode fazer dela seu corpo inorgânico. (Reale \& Antiseri, 2005, p. 176, grifo nosso)

Entretanto, apesar de o trabalho social ser uma dimensão especificamente humana, o "homem" em si nem sempre exerce essa dimensão. Nesse sentido, a teoria de Marx é revolucionária e denuncia as contradições e desigualdades sociais emergidas pelo/no sistema capitalista; regido pelas forças e transformações dos processos históricos (Feracine, 2011). Por essa perspectiva, o "homem", a partir de sua criação (o capital), desumaniza-se, negando a si próprio a sua humanidade.

Nesse contexto, para Marx, o "homem" passou a trabalhar pela subsistência e não pela necessidade ontológica de objetivar-se, de concretizar-se como ser humano. Assim, houve um processo de alienação do trabalho, marcado pela constrição, pela divisão, pela produção e pelo lucro. De modo que o trabalhador tornou-se produto do 
sistema — ou do seu próprio trabalho — “[...] sendo mutilado em sua criatividade e humanidade. O operário é mercadoria nas mãos do capital" (Reale \& Antiseri, 2005, p. 176).

Contudo, para entendermos as principais influências do materialismo histórico e dialético no que tange à psicologia concreta, é fundamental regatarmos a noção de trabalho social, em Marx, partindo de sua raiz humanizadora. Nesse viés, Luria (1991) enfatiza que "as peculiaridades da forma superior de vida, inerente apenas ao homem, devem ser procuradas na forma histórico-social de atividade, que está relacionada com o trabalho social, com o emprego de instrumentos de trabalho e com o surgimento da linguagem" (p. 74, grifo nosso).

Segundo esse autor, é por meio do trabalho social que o "homem" desenvolve atividades mais complexas (superiores). Desse modo, ao traçar uma perspectiva histórica do desenvolvimento psicológico humano, Luria afirma que é a partir desse trabalho que surgem as formas superiores de atividade consciente. Pois, diferente de outros animais, o ser humano prepara/cria seus instrumentos de trabalho. Nessa preparação do instrumento — por exemplo, um arco e flecha para a caça —, há uma reorganização radical na estrutura comportamental e psíquica humana (Luria, 1991).

Dessa maneira, as ações humanas se complexificam em relação às ações dos animais. Desenvolvem, assim, um caráter que transpõe a satisfação imediata de uma necessidade (como se alimentar), que não é dirigido "imediatamente por motivo biológico e [que] só adquire sentido com o emprego posterior de seus resultados" (Luria, 1991, p. 76). O autor afirma, ainda, que muitas vezes essas ações se opõem radicalmente aos motivos biológicos.

O “homem”, portanto, possui objetivos conscientes na criação e manipulação dos seus instrumentos de trabalho. Essa atividade consciente "não é produto do 
desenvolvimento natural de propriedades jacentes no organismo, mas resultado de novas formas histórico-sociais de atividade-trabalho" (Luria, 1991, p. 77).

Percebemos, então, que as explicações das atividades psíquicas humanas, na abordagem histórico-cultural, dão ênfase às relações concretas, de trabalho e manipulação (humanização) da natureza. Assim, a própria noção de humanidade parte de um princípio social: "o homem é um ser de natureza social, que tudo o que tem de humano nele provém de sua vida em sociedade, no seio da cultura criada pela humanidade" (Leontiev, s.d., p. 261).

Por esse viés, Vigotski (2000), em seu Manuscrito de 1929, defende que a constituição de qualquer função psíquica, especificamente humana, dá-se mediante as relações sociais concretas, que têm no trabalho uma dimensão central, conforme apontamos. Com esse argumento, o autor desenvolve a base de sua teoria, elaborando outros conceitos explicativos dos fenômenos psíquicos mais complexos - consciência, imaginação, pensamento, memória, entre outros.

Nesta pesquisa, contudo, daremos ênfase aos conceitos de internalização, mediação semiótica e linguagem. Isso porque eles são essenciais para adentrarmos, adiante, a discussão acerca do sentido na abordagem histórico-cultural, que é um conceito-chave para o nosso tema de estudo.

\subsection{Conceitos norteadores da perspectiva histórico-cultural}

Conforme apontamos, na abordagem histórico-cultural, as funções psíquicas superiores são constituídas nas relações concretas entre as pessoas. Assim, antes de serem internalizadas por um dado sujeito, ou transformadas em uma dimensão subjetiva, essas funções psicológicas foram externas; partiram das relações sociais determinadas por um contexto cultural específico (Vigotski, 2000). Desse modo, a 
internalização das funções superiores fundamenta-se nessa relação com o(s) outro(s) e consigo mesmo; do social dentro de cada um de nós, e vice-versa.

Assim, o desenvolvimento psíquico entrelaça, necessariamente, as relações culturais, e isso significa que a

personalidade torna-se para si aquilo que ela é em si, através daquilo que ela antes manifesta como seu em si para os outros. Este é o processo de constituição da personalidade. Daí está claro, porque necessariamente tudo o que é interno nas funções superiores ter sido externo: isto é, ter sido para os outros, aquilo que agora é para si. Isto é o centro de todo o problema do interno e do externo (Vigotski, 2000, p. 24, grifos nossos).

Pino (2005), contudo, problematiza o conceito de internalização, argumentando que Vigotski utiliza também o termo conversão para indicar um mesmo fenômeno do psiquismo humano. Por essa via, o autor nos alerta que a conversão (ou a internalização) deve ser entendida como uma "mudança de sentido atribuído às coisas ou, ainda, de ressignificação" (Pino, 2005, p. 112).

Essa alteração de sentido implica não apenas em modos diferentes de ver as coisas, mas em novas condutas/orientações psíquicas que transformam o sujeito: a internalização “consiste numa conversão das relações físicas entre as pessoas em relações semióticas dentro da pessoa" (Pino, 2005, p. 112). Dessa maneira, a conversão/internalização é a complexa dinâmica de tornar para si aquilo que antes foi vivido entre e com os outros.

Tal dinâmica de desenvolvimento psíquico — de conversão de algo para si e de alteração de conduta — só pode ser viabilizada por meio das interações sociais, que exigem processos complexos de mediação semiótica (Pino, 2005). O conceito de 
mediação semiótica, por sua vez, relaciona-se diretamente com as premissas, já apresentadas, do materialismo histórico e dialético:

assim como Marx e Engels fizeram do instrumento técnico o mediador das relações dos homens com a natureza, Vigotski faz do signo o mediador das relações dos homens entre si. O paralelismo entre instrumento técnico e signo vai, porém, muito além da sua função de mediação, privilegiada por Vigotski, pois uma análise mais apurada permite-nos perceber que a mesma pessoa que manipula a ferramenta de trabalho imprime à sua ação uma significação, sem a qual a atividade humana dificilmente poderia ser criadora de novas realidades (Pino, 2005, p. 135).

Refletir sobre a mediação semiótica, no contexto da psicologia históricocultural, nos exige também relacioná-la com a ideia de instrumento técnico e signos (e trabalho); como criações especificamente humanas. Para Vigotski, a mediação semiótica é a operação com os signos (Pino, 2005).

O signo é estudado pelo autor bielorrusso em razão de sua natureza simbólica: “o signo, em termos gerais, existe na criação de uma relação de representação [...]" (Fávero, 2005, p. 196) e, consequentemente, de simbolização. Desse modo, o signo não é mera atribuição de significados culturalmente constituídos, mas um conversor que “[...] permite que as significações culturais possam ser incorporadas por cada pessoa" (Pino, 2005, p. 160, grifo nosso).

Um signo pode assumir diferentes significados ao longo da trajetória de um sujeito ou de uma comunidade, devido à sua complexidade simbólica e histórica: "quando utilizamos um martelo, por exemplo, estamos incorporando a nossas ações as experiências das gerações precedentes, uma vez que o próprio martelo, o modo de 
manipulá-lo e a finalidade de seu uso nos são transmitidos nas nossas relações com o outro" (Fontana et al., 1997, p. 60).

Assim, os significados dos signos são dinâmicos e históricos, sendo alterados tanto nos planos culturais, quanto nos subjetivos (Pino, 2005). É o caso do martelo, cujo significado, construído socialmente, refletirá nos modos de sua utilização por um dado sujeito. Usar um martelo de forma " $\mathrm{x}$ " ou " $y$ " faz parte, portanto, de um processo de incorporação das heranças culturais. Mas, devemos ressaltar que se trata de uma incorporação ativa. O "homem”, por essa via, é capaz não apenas de incorporar, mas de transformar e criar suas ferramentas e suas condições de existência:

[ao nascer] o indivíduo é colocado diante de uma imensidade de riquezas acumuladas ao longo dos séculos por inumeráveis gerações de homens, os únicos seres, no nosso planeta, que são criadores. As gerações humanas morrem e sucedem-se, mas aquilo que criaram passa às gerações seguintes que multiplicam e aperfeiçoam, pelo trabalho e pela luta, as riquezas que lhes foram transmitidas e "passam o testemunho" do desenvolvimento da humanidade. (Leontiev, s.d., p. 267)

Nessas dinâmicas de transmissão e criação humanas, os signos assumem protagonismo. Por meio deles, aquilo que é alheio a um sujeito transforma-se (convertese) em algo que lhe seja próprio — sem deixar de ser próprio dos outros, mas mantendo as peculiaridades de cada sujeito (Pino, 2005).

Vigotski defende essa transformação (do alheio em próprio, e vice-versa) quando elucida que o significado das palavras não é constante nem imutável, mas uma potência disponível que se materializa com a sua aplicação subjetiva (HildebrandNilshon et al., 2001) e, consequentemente, objetiva; simultaneamente, particular e coletiva. Dessa maneira, ao tratarmos do conceito de mediação semiótica, 
necessariamente adentramos os processos humanos, de significação e simbolização, que se dão por meio da palavra e, de forma mais ampla, da linguagem.

Fontana et al (1997) diz que, na perspectiva vigotskiana, a linguagem é o sistema de signos mais importante - e mais complexo — desenvolvido pelo "homem". Segundo o autor bielorrusso, a linguagem, em relação dialética com o pensamento, se constitui "no processo do desenvolvimento histórico da consciência humana sendo, elas próprias [linguagem e pensamento], um produto e não uma premissa da formação" (Vigotski, 2001, p. 395).

Uma criança em seus primeiros anos de vida, por exemplo, depende dos processos de mediação semiótica, isto é, de atribuição de significados das coisas pelo outro. Assim, para Vigotski, o ser humano imprime significados às suas ações e os compartilha com seus pares por meio da linguagem (Pino, 2005).

Luria (1991) defende que, "a par com o trabalho, a linguagem é fator fundamental de formação da consciência” (p. 80). Por essa via, novamente enfatizamos o papel da consciência, na abordagem histórico-cultural, como uma categoria importante para pensar o desenvolvimento humano (Ferrari et al., 2010) atrelada à constituição da linguagem. Segundo Luria (1991), "a linguagem imprime ao menos três mudanças essenciais à atividade consciente do homem” (p. 80):

a) a capacidade de discriminar objetos, direcionar a atenção para eles e conservá-los na memória. Resulta, daí, a possibilidade do "homem" de se relacionar com os objetos do mundo exterior, mesmo na ausência desses objetos. Isso porque o "homem" elabora um "mundo de imagens interiores" (p. 80) — aprofundaremos esse fator mais adiante ao discutirmos o conceito de imaginação;

b) a capacidade de definir as propriedades essenciais das coisas, por um processo de abstração e generalização. Viabiliza-se, desse modo, a classificação dos 
objetos de acordo com suas formas e utilidades. Isso torna a linguagem "não apenas meio de comunicação mas também o veículo mais importante do pensamento, que assegura a transição do sensorial ao racional na representação do mundo" (p. 81);

c) a capacidade de assimilar experiências das gerações passadas (histórica e culturalmente marcadas). Assim, o "homem" pode "[...] dominar um ciclo incomensurável de conhecimentos, habilidades e modos de comportamento, que em hipótese alguma poderia ser resultado da atividade independente de um indivíduo isolado" (p. 81).

O autor reforça, ainda, o papel fundamental da linguagem na constituição da consciência, como algo que eleva e transforma radicalmente o patamar dos processos psíquicos humanos. Afinal, é por meio da linguagem que o desenvolvimento cultural se constitui (Pino, 2005). Nessa perspectiva histórico-cultural do desenvolvimento humano, podemos afirmar, portanto, que as funções psíquicas superiores se desenvolvem em razão de um sistema integrado pelos signos, no qual a linguagem assume centralidade.

Essas premissas, observadas na psicologia concreta, parecem coadunar-se com as teorias do pesquisador russo Bakhtin [1895-1975], acerca do papel do signo ideológico na formação do psiquismo. Fundamentando-se também no materialismo histórico e dialético, Bakhtin inovou principalmente nos estudos sobre a influência da ideologia na constituição da linguagem (Yanguello, 2006).

Para o autor, "todo signo está sujeito aos critérios de avaliação ideológica (isto é: se é verdadeiro, falso, correto, justificado, bom, etc). O domínio do ideológico coincide com o domínio dos signos [...]" (Bakhtin, 2006, p. 30). Portanto, todo processo de significação (constituído pela linguagem) é um ato ideológico. 
Já em Vigotski, conforme apontamos, pensar os atos de significação é pensar também a dimensão consciente do "homem". Pois, é pela constituição de um sistema psíquico integrado pelos signos que nos tornamos seres conscientes da nossa própria dimensão cultural no mundo. É interessante notar que essa dimensão, ao mesmo tempo, que diferencia, nós, humanos, dos demais seres da natureza, nos diferencia entre nós mesmos (Laraia, 2006).

Tais diferenciações, conforme abordamos anteriormente em Marx, estão historicamente marcadas por relações de poder. Nesse viés, para Bakhtin (2006), os signos ideológicos são vivos e dinâmicos, constituindo as relações de poder emergentes das tensões entre as lutas de classes. Segundo o autor,

o ser, refletido no signo, não apenas nele se reflete, mas também se refrata. $\mathrm{O}$ que é que determina esta refração do ser no signo ideológico? O confronto de interesses sociais nos limites de uma só e mesma comunidade semiótica, ou seja: a luta de classes. [...] O signo se torna a arena onde se desenvolve a luta de classes. Essa plurivalência social do signo ideológico é um traço da maior importância. Na verdade, é este entrecruzamento dos índices de valor que torna o signo vivo e móvel, capaz de evoluir. O signo, se subtraído às tensões da luta social, se posto à margem da luta de classes, irá infalivelmente debilitar-se [...] (Bakhtin, 2006, p. 45-46).

Veremos adiante, nas discussões sobre o conceito de cultura popular, como essas relações de poder (luta de classes) são estruturadas por meio dos signos ideológicos (ou as formas de comunicação ideológica). Mas, trataremos neste momento de outro conceito caro para nossa pesquisa, o sentido — que, na abordagem históricocultural, é também atrelado a uma das dimensões da linguagem/palavra. Contudo, veremos que, na obra de Vigotski, o sentido do sentido também é investigado no âmbito 
da psicologia da arte (Namura, 2003; s.d.); particularmente no que se refere às emoções suscitadas pela experiência estética e é, justamente, essa dimensão do conceito que mais nos interessa.

\subsection{O sentido em Vigotski: linguagem e experiência estética}

O conceito de sentido em Vigotski, segundo Namura (s.d.), pode ser estudado principalmente em duas grandes obras do autor bielorrusso: Psicologia da arte, de 1925, e Pensamento e linguagem, de 1934. Nas discussões do termo, atreladas aos estudos sobre linguagem, "o sentido, objetivado em palavras, é a categoria mais importante da consciência" (Namura, s.d., p. 1). Entretanto, é fundamental ressaltar que significado e sentido são conceitos distintos quando nos referimos à dimensão da palavra.

Conforme abordamos, o significado da palavra, como fenômeno do pensamento discursivo ou da atividade consciente, é "a unidade da palavra com o pensamento" (Vigotski, 2001, p. 398). Para Vigotski, o significado é apenas a dimensão mais estável, coerente e precisa da zona dos sentidos (Cruz, 2011). Contudo, Pino (2005) alerta que o significado é constitutivo da própria língua; como uma formação dinâmica, histórica e culturalmente compartilhada. Por essa via, ao mesmo tempo que assume uma dimensão mais precisa, dentro da língua, o significado é dinâmico, pois a própria língua é viva e dinâmica.

Já o sentido diz respeito a um aspecto mais particular, assim, o significado de uma palavra pode assumir sentidos diferentes para cada locutor em um determinado discurso (Pino, 2005). Esse sentido relaciona-se, também, à dimensão afetiva, pois se estabelece naquilo que se torna valioso internamente: "o afetivo se constitui pelo que a linguagem traz de valor, de tons para o interior do sujeito" (Barbosa, 2011, p. 21). Para 
as autoras Wortmeyer, Silva e Branco (2014), essa dimensão dos afetos é bastante desafiadora e, em termos genéricos, contempla os estudos das emoções, das paixões e dos sentimentos.

No que tange à linguagem, tanto Vigotski, quanto Bakhtin, relacionam seu estudo intrinsecamente com a emoção e o sentido (Barbosa, 2011). Desse modo, Freitas (2007) afirma que a linguagem é produção de sentidos — produção, esta, que abarca necessariamente a dimensão afetiva.

Contudo, ao abordarmos o campo dos sentidos atrelado à linguagem, devemos entender também que esta vai além de sua dimensão verbal (ou da própria língua). Para Bakhtin (2006), a "massa de outras reações gestuais com valor semiótico" (p. 51), como as expressões corporais, a tonalidade com que determinado discurso é expresso, a emoção que lhe é inerente, tudo isso é fundamental na constituição de sentidos.

Ao estudar as emoções humanas com base em Vigotski e Bakhtin, Magiolino (2011) afirma que estas estão no âmago de tudo que o que tem sentido. Para a pesquisadora, as emoções constituem os processos pedagógicos e psicológicos, éticos e estéticos, as relações entre a arte e a vida. Por essa via, considerar as emoções humanas nos processos de constituição de sentidos implica também olhar para o corpo, as formas, a dimensão (est)ética das experiências vividas (Magiolino, 2011). Desse modo, enfatizamos que as emoções afetam e dão sentido às nossas experiências e condutas, que são concretas e estéticas.

Por esse viés, a pesquisadora Namura (2003, s.d.) evidencia que, em Vigotski, outra perspectiva para elucidar o sentido do sentido é desenvolvida à luz da psicologia da arte e abarca especificamente o campo das emoções estéticas: "a arte é um conjunto de signos estéticos destinado a causar emoções nas pessoas” (Namura, s.d., p. 2). Dessa 
maneira, a emoção estética é estudada por Vigotski (1999a) numa tentativa de elucidar as "leis psicológicas de influxo da arte sobre os homens" (p. 23).

Essa dimensão é fundamental nesta pesquisa, por abarcar justamente a concepção de sentido atrelada às emoções estéticas, suscitadas pela experiência artística. No terceiro capítulo, veremos que o brincar do adulto, no universo da cultura popular, é também uma prática artística (criativa e criadora) que, na realidade, se encontra no limiar entre a arte e a vida. Por enquanto, pretendemos argumentar que a ideia de sentido ultrapassa as noções meramente linguísticas, adentrando uma dimensão mais ampla - e necessariamente estética — da vida. Nessa perspectiva, atribuir sentido é uma condição humana, mas os sentidos atribuídos mudam, se transformam e adquirem novos conteúdos, significados e qualidades no processos histórico-social de desenvolvimento do homem. Dessa forma, as ideias, as estruturas sociais e as concepções ideológicas que dão sentido à vida podem se transformar, desaparecer e renovar-se; podem ser produzidas e comunicadas diretamente na expressão linguística, podem ser apreendidas indiretamente pelos fatos, acontecimentos, costumes, modos de ser e viver, enfim, as concepções de sentido se transformam nas infinitas relações sociais. (Namura, 2003, p. 2, grifo nosso)

Assim, compreendendo a atribuição de sentido à própria experiência, como uma condição humana, Namura (2003) investiga o sentido do sentido em Vigotski por meio de uma aproximação com a estética e a ontologia do ser social em Lukács. A autora argumenta que historicamente o sentido deixou de se vincular às experiências sensoriais, éticas e à razão, sendo substituído pelas inovações tecnológicas e pelo fetichismo das mercadorias (Namura, 2003). 
Com a era moderna, a partir do século XVIII, que incrementou a ideologia capitalista, transformações sociais direcionaram paulatinamente a humanidade ao individualismo. Logo, "as bases materiais, ontológicas, éticas e estéticas do sentido da modernidade, do sujeito emancipado, da sociabilidade e da realidade subjetiva" (Namura, 2003, p. 16) cederam espaço para o sentido da insegurança, da fragmentação e da perda de sentido; na verdadeira essência (emancipadora) que o conceito comporta.

Desse modo, Namura (2003) enfatiza a importância de compreender o sentido em sua raiz ontológica no que tange, especificamente, à psicologia proposta por Vigotski. Nessa compreensão, a autora reforça que a estética comparece, em Vigotski, Marx e Lukács, como uma dimensão essencial das experiências humanas: "de constituição do sujeito, da subjetividade e, portanto, do próprio sentido" (p. 24).

Por essa via do sentido, na obra de Vigotski a estética é estudada com centralidade nas emoções suscitadas pela arte, conforme apontamos. Essas emoções, provocadas pela experiência estética, se diferenciam das emoções ordinárias (Wortmeyer et al., 2014). Pois, seguindo de forma contrária à lei do menor esforço, que se refere à economia psíquica de descargas de energias nervosas, as emoções suscitadas pela arte (reações estéticas ou comportamento estético) produzem um alto dispêndio de energia (Vigotski, 1999a). Esse dispêndio de energia provoca modificações "da vontade, dos sentimentos e do desejo" (Namura, 2003, p. 200) e é explicado pelo conceito de catarse, que estudaremos no capítulo a seguir. 


\section{EXPERIÊNCIA ESTÉTICA}

Os estudos sobre arte e estética estão tão articulados que Bayer (1978), autor importante no campo da teoria estética, introduz seu livro História da Estética mencionando as obras de arte na pré-história e a busca pelo belo, por exemplo. De forma parecida, Suassuna (2005), em Iniciação à Estética, mapeia a natureza e o objeto desse campo localizando-o na filosofia. Segundo este autor, em suas as suas raízes históricas (clássicas) a estética era denominada filosofia do belo.

Porém, corroborando com o pesquisador francês Bourriaud (2009), entendemos que a experiência estética não se resume às experiências artísticas - consideradas, por vezes, belas -, mas é, na realidade, uma dimensão mais ampla da própria experiência humana; que perpassa o cotidiano ou as vivências ordinárias. Desse modo, Bourriaud (2009) argumenta que a estética é um campo da filosofia (e da psicologia, para nós) que aborda a dimensão a vida humana como forma e ritual. Enterrar os mortos, por exemplo, faz parte dessa dimensão (Bourriaud, 2009).

Contudo, nessa perspectiva, o campo da arte é considerado privilegiado por necessariamente tratar de expressões que possuem materialidade, forma; seja ela oral/escrita, gestual/corporal, visual, musical etc. Apontamos isso porque, neste capítulo, interessa-nos estudar justamente a estética à luz da arte. Veremos adiante que, no que tange à psicologia da arte, defendida por Vigotski, o conceito de estética diz respeito à dimensão criativa e artística do "homem".

Por essa via, a estética fundamentada na psicologia concreta (materialista, histórica e dialética) é uma “[...] categoria da particularidade, [que] anuncia a direção ontológica e as especificidades do ser social" (Namura, 2003, p. 26). É, portanto, uma dimensão dos "homens concretos e vivos" (p. 27). Assim, partimos dessa concepção 
estético-ontológica que considera o "potencial transformador e emancipador da arte" (p. 27).

\subsection{Arte, criação e imaginação}

A arte é tão antiga quanto a própria humanidade (Fischer, 1987). Para Vigotski (2009), ela é uma atividade estética viabilizada pela imaginação. Desse modo, a imaginação é um conceito fundamental e perpassa todas as discussões sobre arte e experiência estética, na obra do autor bielorrusso.

Como fenômeno do psiquismo, a imaginação é estudada por Vigotski (1999, 2009) com ênfase nas emoções estéticas. Em sua célebre obra, Psicologia da Arte, o pesquisador enfatiza que "toda emoção se serve da imaginação [...]. Além de uma ação periférica, a emoção exerce ainda uma função central e que, neste caso [da psicologia da arte], deveríamos tratar precisamente desta" (Vigotski, 1999, p. 264, grifo nosso). Assim, tanto as emoções como a imaginação estão no cerne dos estudos sobre experiência estética (ato estético ou criação artística), em Vigotski.

Por isso, neste capítulo, ao abordarmos os estudos sobre imaginação, criação e arte, adentramos, novamente, as discussões acerca das emoções estéticas; principalmente no que tange o conceito de catarse, em Vigotski. Inicialmente, contudo, apontamos algumas pesquisas que se debruçam sobre os conceitos de imaginação e criação $^{5}$, visando, posteriormente, relacioná-los às experiências estéticas dos/as brincantes populares; precisamente, à produção de sentidos que constituem os/as próprios/as brincantes.

\footnotetext{
5 Neste momento, é importante enfatizar que a psicologia histórico-cultural é dialética, conforme discorremos no capítulo 1. Desse modo, não podemos entendê-la partindo de um princípio linear, em que uma determinada função psíquica (imaginação, consciência, memória, etc.) desencadeia o desenvolvimento de outra, mas como um sistema integrado, em que todas elas viabilizam uma dimensão psicológica singular; referente à constituição humana.
} 


\subsection{Imaginação e criação como exceção}

As noções psicológicas contemporâneas sobre o conceito de imaginação ainda estão bastante arraigadas às elaborações filosóficas desenvolvidas na antiguidade clássica, por filósofos como Platão e Aristóteles, até o período mais recente, denominado de modernidade europeia, os séculos XVIII e XIX (Silva et al, 2010).

Na agenda científica ocidental da modernidade, por exemplo, a imaginação foi compreendida como uma faculdade vigorante principalmente nos gênios e nos loucos (Silva et al., 2010). Nessa perspectiva, que corrobora para o reforço de noções individualistas, como dom e genialidade, a imaginação torna-se antônimo de razão.

A razão, por sua vez, é historicamente vinculada às práticas científicas e sérias. Assim, a arte, enquanto uma produção imaginativa que incorpora o espaço da fantasia, transforma-se em uma atividade relegada a sujeitos infantilizados e ociosos (Silva et al., 2010). Por essas vias, observamos que, ao mesmo tempo que a atividade artística pode ser infantilizada e subestimada socialmente, ela também é, estranhamente, exaltada na figura do gênio. Assim:

parece claro que os aspectos mais perturbadores e extremos da imaginação se associaram melhor com os territórios periféricos ou excêntricos da imaturidade e sensibilidade psicológica — a das crianças, dos selvagens, da cultura popular, etc. —, a anormalidade e irracionalidade psicopatológica dos loucos, dos degenerados, dos decadentes — ou, como supunha Kant, a excepcionalidade de caráter ou o temperamento — dos gênios, dos grandes homens, dos líderes, dos heróis, etc. (Silva, Castro-Tejerina \& Barbarato, 2010, p. 10, tradução nossa, grifo nosso)

Percebemos que essa contradição acerca do conceito de imaginação, que situa os poucos sujeitos imaginativos nas hierarquias sociais mais inferiores (loucos, infantis) 
ou mais superiores (gênios, artistas, heróis), ainda reverbera em nossos tempos. Veremos isso, adiante, quando tratarmos especificamente do conceito de arte e cultura popular, em que a questão da imaturidade psicológica, atrelada ao popular, fica evidente nas práticas sociais que desvalidam as expressões populares como não sérias ou desmerecedoras de prestígio político, econômico etc.

Sobre essa noção infantilizada e ociosa da imaginação, o escritor Suassuna ${ }^{6}$ (1979) apresenta uma crítica interessante em sua peça A Farsa da Boa Preguiça. Provida de bastante humor e rima, a obra enfatiza as supostas relações entre criação artística e (boa) preguiça subvertendo a noção desprestigiadora sobre as atividades imaginativas e o próprio ócio; vigorante nas elaborações filosóficas ocidentais por vários séculos, conforme apontamos.

A peça gira em torno das peripécias do poeta-cantador Simão, personagem que justifica suas inúmeras criações por meio do ócio criativo, segundo o qual: é necessário um tanto de boa preguiça para que a imaginação possa ganhar forma, possa ser, de fato, artística $^{7}$. Porém, esse ócio criativo, defendido pela figura de Simão, é também socialmente encarado como improdutividade. Essa ideia comum a grande parte do povo, na trama, remonta-nos às noções psicológicas sobre o termo imaginação, em que a atividade artística é considerada algo infantil, que não permeia as atividades sérias ou o mundo do trabalho adulto.

De um modo geral, no contexto da peça - que se passa no sertão do Nordeste brasileiro - , percebemos, pela crítica do povo ao poeta, que imaginação e arte não

\footnotetext{
${ }^{6}$ Pesquisador, poeta, dramaturgo e político, Ariano Suassuna [1927-2014] foi um grande colaborador da cultura popular brasileira. Escreveu diversas obras literárias que tecem, com humor, o imaginário, os hábitos, os costumes e as crenças dos nordestinos.

${ }^{7}$ No próximo capítulo, criticamos essa ideia de ociosidade vigorante também nas expressões lúdicas; mais especificamente no brincar.
} 
enchem a barriga. Contudo, paradoxalmente, o pobre poeta e cantador é também prestigiado pela mesma comunidade, por emocionar e comover com as suas artimanhas.

Nesse viés, entendemos que, mesmo sem encher a barriga, a arte preenche determinadas necessidades humanas que, obviamente, não são supridas pela comida ou falta dela. Mas que necessidades seriam essas? Qual é o sentido da arte na vida humana? Seriam imaginação e criação funções relegadas apenas aos artistas, aos loucos e às crianças? Para discutir essas inquietações, recorremos adiante às contribuições de Vigotski, que situam imaginação e criação muito mais como regra (de todos) do que como exceção (dos gênios, dos loucos e das crianças).

\subsection{Imaginação e criação como regra}

Segundo Vigotski (2009), a imaginação e as manifestações inventivas são pilares fundamentais para a compreensão dos processos criativos especificamente humanos, portanto, todo sujeito é um ser criador. Longe de ser um ato ocioso da mente, a imaginação é uma necessidade vital, vinculada à criação. Assim, as criações, emergentes desses processos imaginativos, devem ser vistas mais como "[...] regra do que como exceção" (Vigotski, 2009, p. 16). Dessa forma:

numa perspectiva materialista, histórica e dialética, Vigotski defende que o processo de criação não se reduz ao trabalho produzido por grandes cientistas, gênios ou artistas, mas que envolve também as criações cotidianas de qualquer sujeito. Em toda a ação humana há, para o autor, uma fagulha de criação. (Magiolino, 2015, p. 145)

Ainda para o autor bielorrusso, a imaginação emerge da e na realidade e se subordina "à experiência, às necessidades e ao interesse" (Vigotski, 2009, p. 41) de um dado sujeito ou grupo social: "há uma dependência mútua entre imaginação e 
experiência. Se no primeiro caso a imaginação apoia-se na experiência, no segundo é a própria experiência que se apoia na imaginação" (Vigotski, 2009, p. 25), dialeticamente.

Vigostki (2009) enfatiza, então, a relação indissociável entre imaginação e realidade. Assim, mesmo nos casos mais fantásticos, como em delírios patológicos, a imaginação fundamenta-se no real. Isso porque o autor entende, inclusive, as bases emocionais humanas como experiências absolutamente reais: "todas as nossas vivências fantásticas e irreais transcorrem, no fundo, numa base emocional absolutamente real" (p. 264).

Nesse viés, o autor defende que há dois tipos de atividades simbólicas decorrentes da plasticidade do cérebro humano. Um desses tipos, denominado atividade reprodutiva, baseia-se na repetição dos rastros de antigas impressões, algo que já existia na conduta humana ou já fora vivenciado: "sua essência consiste em reproduzir ou repetir meios de conduta anteriormente criados e elaborados ou ressuscitar marcas de impressões precedentes" (Vigotski, 2009, p. 11). O outro, que mais nos interessa, é denominado atividade combinatória, ou criadora, e parte da combinação e reelaboração de experiências anteriores.

Para Vigotski (2009), o círculo completo da atividade criadora é "concluído quando ela se encerra ou se cristaliza em imagens externas" (p. 39). Esse encerramento é denominado pelo autor como imaginação cristalizada ou encarnada. Segundo ele, as diversas manifestações inventivas, entre as quais encontramos a arte, são viabilizadas pela objetivação de um ciclo imaginativo que se encerra. Essa imaginação cristalizada ou encarnada, por sua vez, é constituída por alguns fatores:

a) a necessidade de adaptação do ser humano ao meio que o cerca, pois, um ser completamente adaptado não possui necessidades de criação: nem desejos, nem anseios de mudança. Assim, a inadaptação impulsiona as ações inventivas; 
b) a ressurreição espontânea de imagens, que deriva de algo que "[...] ocorre de repente, sem motivos aparentes” (p. 40). Vigotski (2009) explica tal ressurreição de acordo com as contribuições de Ribot sobre o conceito de criação espontânea. Esta é uma condição adicional para que os anseios, os desejos e as necessidades subjetivas se materializem. A criação espontânea é uma espécie de origem motriz da criação: "os motivos existem [necessidades, desejos, anseios], mas suas ações estão ocultas em formas latentes do pensamento por analogia, do estado afetivo, do funcionamento inconsciente do cérebro" (Ribot conforme citado por Vigotski, 2009, p. 40). Logo, essas latências são também propulsoras da imaginação cristalizada; e

c) a subordinação à experiência, que "[...] depende da capacidade combinatória e do seu exercício, isto é, da encarnação dos frutos da imaginação em forma material" (p. 41). Assim, autor ressalta a importância das condições externas (do meio circundante). As criações dependem do conhecimento técnico de um sujeito, e esse conhecimento é impulsionado pelas condições históricas e culturais em que ele se encontra: "a criação é um processo de herança histórica em que cada forma que sucede é determinada pelas anteriores” (p. 42). Não há como existir, por exemplo, um grande pianista em uma sociedade onde o piano ainda não foi inventado. Contudo, ao mesmo tempo que, de certo modo, um sujeito é fruto do seu tempo e meio, ele também é construtor, é um ser ativo.

Esse fator da criação e invenção, apontado no item c, é fundamental, pois implica um aprofundamento sobre outro conceito caro a nossa pesquisa: a autoria. Isso porque, no tange à cultura popular, há uma grande discussão sobre a dimensão anônima das produções artísticas, que, em maioria, são denominadas como domínio público. Sobre isso, o professor Nelson Inocêncio, em suas aulas de arte e cultura popular ${ }^{8}$,

\footnotetext{
${ }^{8}$ Disciplina Elementos de Linguagem, Arte e Cultura Popular (Instituto de Artes/UnB), cursada em 2006.
} 
destacava como, inúmeras vezes, o domínio público camufla a falta de reconhecimento das manifestações populares no Brasil.

Na psicologia histórico-cultural, contudo, Vigotski (2009) problematiza a noção de invenção (sejam elas artísticas, científicas, cotidianas etc.) tendo como base que "nenhuma invenção será estritamente pessoal, já que sempre envolve algo de colaboração anônima" (Ribot conforme citado por Vigostki, 2009, p. 42). Desse modo, a autoria de toda criação (ou imaginação cristalizada/encarnada) será sempre resultante da ampla trama social na qual ela é gerada.

Um exemplo interessante sobre essa dimensão anônima, atrelada às contribuições populares, é evidenciado por Vigotski (1999), ao abordar precisamente a obra do poeta e romancista russo Púchkin [1799-1837]. Para o pesquisador,

[...] o antigo ponto de vista, segundo o qual existiria uma diferença de princípio entre os processos e produtos da criação popular e individual, parece hoje abandonado por unanimidade. Hoje ninguém afirmaria que a bilina [canção épica] russa, registrada a partir das palavras de um pescador de Arkhánguelsk, e um poema de Púchkin, cuidadosamente corrigido por ele nos manuscritos, são produtos de diferentes processos de criação. [...] É absolutamente falsa a concepção segundo a qual a poesia popular surge sem artifícios e é criada por todo o povo e não por profissionais - narradores, cantores, fabuladores e outros profissionais da criação artística —, donos da técnica do seu ofício, rica e profundamente especializada, da qual fazem uso exatamente como os escritores das épocas mais tardias. Por outro lado, o escritor que fixa o produto escrito da sua criação também não é, absolutamente, o criador individual da sua obra. Púchkin não é, de modo algum, o autor individual do seu poema. (Vigotski, 1999, p. 15-16, grifos nossos) 
O pesquisador evidencia, portanto, a participação coletiva nos processos de criação, seja de um pescador fabulador - que acaba, inúmeras vezes, por se tornar anônimo no decorrer das tensões sociais historicamente marcadas —, seja de um renomado escritor, que também não foge à essas tensões. Logo, a dimensão coletiva da autoria nas invenções humanas marca a nossa constituição subjetiva, de modo que, mesmo se tratando de uma obra atribuída a um único escritor, conforme nos aponta Vigotski (1999), ela será sempre fruto das ações (e aprendizados) coletivas; culturais.

Notamos que essa dimensão da autoria, em Vigotski, dialoga profundamente com as concepções bakhtinianas acerca da memória dos objetos culturais. Em Bakhtin, todos os objetos culturais são discursos portadores de memórias sobre aqueles que vieram antes: "trata-se de uma memória que está na cultura e em seus objetos. Ela perpassa as relações intersubjetivas e as constitui ao mesmo tempo em que é atualizada por elas" (Amorim, 2009, p. 10).

Em alguns desdobramentos interpretativos, percebemos que nem um ato criador, em Vigotski, nem um objeto cultural, em Bahktin, é novo e exclusivo de um ato isolado de um sujeito, mas sempre um rememorar de algo que já se passou com outros sujeitos (Amorim, 2009). Ao mesmo tempo, ele nunca é velho, por estar em constante atualização articulada às singularidades dos múltiplos discursos/enunciações culturais: o momento histórico, a dimensão afetiva do discurso, os ouvintes a quem se destina, a memória coletiva que abarca etc. Assim, um discurso — ou um ato inventivo, conforme apontamos - é igualmente criador de futuro e recriador de passado (Amorim, 2009).

Desse modo, não há criação sem apropriação e repetição, tanto em Vigotski quanto em Bakhtin; não há novidade sem assumir/incorporar o antigo. Qualquer objeto ou ato criativo parte desse sistema dialético - e, portanto, contraditório - que abarca o 
novo e o velho ao mesmo tempo. É interessante notar, também, que o próprio conceito de imaginação encarnada, em Vigotski, parece carregar a concepção de incorporar algo externo, de encarnar o outro (ou os outros) em uma dada expressão criativa. Assim, qualquer inventor

é sempre fruto de seu tempo e de seu meio. Sua criação surge de necessidades que foram criadas antes dele e, igualmente, apoia-se em possibilidades que existem além dele. [...] A criação é um processo de herança histórica em que cada forma que sucede é determinada pelas anteriores (Vigotski, 2009, p. 42).

Contudo, apesar de todo ato criador partir desse dilema entre o novo e o velho, existe uma diferenciação conceitual, fundamental para a nossa pesquisa, entre as invenções não artísticas e as artísticas. A arte, segundo Vigotski (1999), é "uma espécie de sentimento social prolongado ou uma técnica de sentimentos" ${ }^{\text {9 }}$ (p. 308, grifos nossos) diferenciada principalmente pela emoção que desperta por meio de seus múltiplos atos, discursos e objetos; emoções estéticas, conforme apontamos no capítulo anterior.

Assim, diferente das emoções geradas na/pela vida ordinária, a obra de arte, e mais precisamente a reação humana a uma obra de arte, transforma um sentimento individual em social, generalizando-o e "superando certo aspecto do psiquismo que não encontra vazão na vida cotidiana" (Vigotski, 1999, p. 308). Essa superação de determinados aspectos psíquicos é explicada pelo conceito de catarse.

\footnotetext{
${ }^{9}$ Vigotski (1999) defende que a "arte é o social em nós" (p. 315). Assim, o seu efeito, catártico, é um efeito social. Contudo, o autor se contrapõe a teoria do contagio, e defende que "a refundição das emoções fora de nós realiza-se por força de um sentimento social que foi objetivado, levado para fora de nós, materializado e fixado nos objetos externos da arte, que se tornaram instrumento da sociedade" (p. 315).
} 


\subsection{Catarse: psicologia da arte}

Enquanto um processo psíquico complexo, a catarse, em Vigotski (1999), é uma reação estética causada pela obra artística. Segundo o autor bielorrusso, “[...] nenhum dos elementos da obra de arte é importante em si. Não passa de uma tecla. $\mathrm{O}$ importante é a reação estética que suscita em nós” (p. 259).

Por essa via, Vigotski (1999) dá ênfase às emoções/sentimentos viabilizadas/os pela experiência estética, artística. Desse modo, o autor contrapõe-se às vertentes psicológicas da arte de seu tempo, que:

a) ora centram-se no estudo da personalidade do artista, no prazer estético e na avaliação - psicologia reflexológica/experimental —, e não separam "a emoção estética da emoção comum" (p. 19);

b) ora elegem apenas as condições sociais — estudos sociológicos — que não possuem capacidade "de explicar integralmente o próprio mecanismo de ação (psicológica) da obra de arte" (p. 21), principalmente porque partem de uma ideia equivocada do social, como multidão ou "reunião de pessoas e condição suplementar da atividade de um indivíduo" (p. 13-14).

Desse modo, Vigotski (1999) propõe um enfoque marxista na psicologia da arte; que é necessariamente materialista, histórico e dialético como vimos no capítulo anterior. O autor privilegia, então, o “estudo da ação psicofísica da obra de arte” (p. 12), com ênfase na própria obra e naquilo que ela suscita no "homem":

para nós, é mais evidente que as operações intelectuais, os processos intelectivos que surgem em cada um de nós com ajuda e por motivação da obra de arte não pertencem à psicologia da arte stricto sensu. São uma espécie de resultado, de efeito, de conclusão, de consequência da obra de arte. (p. 43) 
Nesse sentido, Vigotski (1999) aponta a necessidade de estudar a própria estrutura da obra, explorando em suas análises a arte literária — mais precisamente, a fábula, a novela e a tragédia. $\mathrm{O}$ autor justifica tal escolha partindo do argumento de que essas estruturas (gêneros) comportam as formas mais elementares e mais complexas da arte (literária). Todas essas obras são, também, regidas por uma estrutura contraditória, entre forma e conteúdo: "toda obra de arte implica uma divergência interior entre conteúdo e forma, e que é precisamente através da forma que o artista consegue o efeito de destruir ou apagar o conteúdo" (Vigotski, 1999, p. 272), evocando no leitor (apreciador) emoções opostas simultaneamente, como agrado e desagrado, dor e triunfo, por exemplo.

Segundo o autor, não existe apenas uma contradição lógica na estrutura concreta da obra, mas também - e principalmente - uma contradição emocional gerada por ela: “a emoção do leitor da fábula é, em seu fundamento, uma emoção de sentimentos opostos que se desenvolvem com a mesma intensidade e em completa contiguidade" (p. 170). Essa experiência estética, contraditória, é ele entende por catarse.

A catarse é um conceito central para a estética de Vigotski (Namura, 2003). Segundo o autor bielorruso, ela é um princípio da lei da reação estética, que "encerra em si a emoção que se desenvolve em dois sentidos opostos e encontra sua destruição no ponto culminante, como uma espécie de curto-circuito" (Vigotski, 1999, p. 270). Desse modo, a reação psicológica causada pela arte ocorre por meio de uma descarga intensa de emoções, contrariando a lei do menor esforço do organismo humano ${ }^{10}$. Vigotski defende que a catarse é um processo complexo de "transformação das emoções" (p. 272).

\footnotetext{
${ }^{10}$ Conforme apontamos no capítulo 1 (ver página 34).
} 
Nesse viés, o autor argumenta ainda que a arte é uma necessidade humana de superar certos aspectos psíquicos que não "encontram vazão na nossa vida cotidiana" (Vigotski, 1999, p. 308). Esses aspectos são, ao mesmo tempo, destruidores e transformadores da nossa condição humana (Vigotski, 1999).

Sobre esse assunto, a pesquisadora Namura (2003) enfatiza que a catarse, em Vigotski, é "um momento de modificação da vontade, dos sentimentos e do desejo. Ela não engendra, mas prepara para a ação, não reproduz, mas cria a vida dotada de um sentido fundado na real condição de emancipação do homem (p. 200-201, grifos nossos). A catarse é, portanto, uma experiência instauradora de sentidos (Namura, 2003). Sentidos, estes, que emancipam o "homem" e "decorrem de sua riqueza" (Vigotski, 2010, p. 339), daquilo que é "mais rico do que a sua vida" (p. 339). Para o autor, é esse o milagre da arte, aquilo que vai além da pobreza e da fome humana:

[...] a arte não é uma complementação da vida mas decorre daquilo que no homem é superior à vida. O "milagre" da arte lembra antes [à multiplicação dos pães e dos peixes] a transformação da água em vinho, e por isso toda obra de arte sempre implica algum tema real concreto ou uma emoção absolutamente comum ligada ao mundo. Mas a tarefa do estilo e da forma consiste justamente em superar esse tema referencial ou o colorido do emocional do objeto e transformá-lo em algo absolutamente novo. Por isso, desde os tempos mais remotos, compreende-se o sentido da atividade estética como catarse, ou seja, a libertação do espírito diante das paixões que o atormentam (Vigotski, 2010, p. 340, grifo nosso).

Na citação acima, do livro Psicologia Pedagógica, em que se discute a reação estética, o autor utiliza duas referências bíblicas, acerca dos milagres de Jesus, para explicar a catarse, como uma transformação radical das emoções; um milagre. Ainda 
nesse exemplo, Vigotski (2010) explicita que o termo catarse é bastante anterior às suas elaborações.

Em outra obra (Psicologia da Arte), o autor explica que o termo, catarse (psicofísica), foi formulado na antiguidade clássica por Aristóteles, mas enfatizamos que Vigotski se apropria e reformula o termo partindo de uma dimensão estéticaontológica. Porém, o pesquisador elucida também que, mesmo com divergências, o termo aristotélico foi o que mais se aproximou do seu conceito:

apesar da imprecisão do seu conteúdo e da manifesta recusa à tentativa de esclarecer o seu significado no texto de Aristóteles, ainda assim supomos que nenhum outro termo, dentre os empregados até agora na psicologia, traduz com tanta plenitude e clareza o fato, central para a reação estética, de que as emoções angustiantes e desagradáveis são submetidas a certa descarga, à sua destruição e transformação em contrários, e de que a reação estética como tal se reduz, no fundo, a essa catarse, ou seja, à complexa transformação dos sentimentos. (Vigotski, 1999, p. 270, grifo nosso)

É interessante perceber que Vigotski não se opõe completamente às formulações aristotélicas do termo catarse, mas as reformula, partindo de um princípio metodológico dialético, conforme evidenciamos no capítulo anterior. Assim, em Aristóteles,

a função do drama [da arte] era purificar as emoções, superando o terror e a piedade, de maneira que o espectador, ao se identificar com Orestes ou Édipo, viesse a ser por sua vez libertado daquela identificação e se erguesse acima da ação cega do destino. (Fischer, 1987, p. 14, grifo nosso)

Já em Vigotski (1999), essa superação de dados aspectos do psiquismo humano, na catarse, está ligada a uma transmutação de sentimentos, a uma nova forma 
da pessoa compreender a si mesma e o mundo que a cerca, ocasionando uma ressignificação ${ }^{11}$ de suas emoções e vontades — uma alteração profunda dos sentidos de sua vida, de seus anseios e condutas.

O autor bielorrusso enfatiza, ainda, que as reações estéticas suscitadas pela arte "são vivenciadas com toda força e realidade, mas encontram sua descarga [na] fantasia. [...] É nessa unidade de sentimento e fantasia que se baseia qualquer arte" (Vigotski, 1999, p. 272). Desse modo, a fantasia (ou a imaginação), como discorremos, viabiliza as criações artísticas, pois estas, além de outros tipos de criações, são a própria imaginação encarnada ou cristalizada.

Já enfatizamos também que qualquer criação possui uma dimensão social e que nunca é um ato isolado de um único sujeito. Resgatamos essa característica aqui, pois ela é fundamental para entendermos o sentido social na psicologia da arte proposta por Vigotski (1999) — sentido que, em nosso entendimento, torna a (re)formulação do conceito de catarse bastante original.

Segundo o autor, a reação estética à obra de arte, como um processo catártico, necessariamente integra um sentido social maior:

a arte é o social em nós, e, se o seu efeito se processa em um indivíduo isolado, isto não significa, de maneira nenhuma, que suas raízes e essência sejam individuais. [...] O social existe até onde há um homem e as suas emoções pessoais. Por isso, quando a arte realiza a catarse e arrasta para esse fogo purificador as comoções mais íntimas e mais vitalmente importantes de uma alma individual, o seu efeito é um efeito social (p. 315).

Por isso, Vigotski (1999) defende a ideia de que "arte é uma técnica social do sentimento", em que, pela vida social, incorporamos "os aspectos mais íntimos e

\footnotetext{
${ }^{11}$ Bastante dramática e contraditória, conforme veremos adiante, ao abordarmos o conceito de drama.
} 
pessoais do nosso ser" (p. 315). Os sentimentos relacionados à reação/experiência estética tornam-se pessoais sem, conduto, deixarem de ser sociais (Vigotski, 1999). Nessa perspectiva, o autor argumenta - em outra obra que discute o trabalho criativo do ator - que é justamente esse sentido social da arte que viabiliza o trânsito da psicologia para a ideologia:

estudar a ordem e a conexão dos afetos é a principal tarefa da psicologia científica, porque não é nas emoções tomadas de uma forma isolada, mas em conexões com sistemas psicológicos mais complexos, que a solução do paradoxo do ator reside. Esta solução, como pode ser esperada ainda agora, conduzirá os investigadores a uma posição que tem uma significância fundamental para toda a psicologia do ator. As experiências do ator, suas emoções, aparecem não como funções de sua vida mental pessoal, mas como um fenômeno que tem uma significância e um sentido social objetivos, que servem como um estágio de transição da psicologia à ideologia (Vigotski, 2009b, p.21, grifos nossos).

Por essa via, em alguns desdobramentos interpretativos, novamente identificamos as valiosas contribuições de Bakhtin (2006) no que tange, especificamente, à noção de ideologia atrelada à arte. Segundo o pesquisador russo, a arte é uma forma de comunicação ideológica, composta por signos ideológicos, como já enfatizamos. Ela parte, portanto, dessa dinâmica dos confrontos de interesses sociais (Bakhtin, 2006), ao mesmo tempo que possui a capacidade de transformá-los — não a arte como obra isolada (objeto morto), mas aquilo que ela afeta nos "homens" vivos.

Por isso, a arte também se articula aos processos históricos e culturais mais amplos, que definem inclusive o que é e o que não é considerado artístico em uma sociedade. Bulhões $(1991,2005)$ apresenta reflexões interessantes acerca dos sistemas 
sociais que dimensionam, identificam, rotulam, vendem e institucionalizam aquilo que é conceituado como arte. Para a autora, a história das artes

[...] manteve-se tradicionalmente dedicada a identificar e consagrar os artistas e as obras clássicas, incorporando, progressivamente, como tais as manifestações contemporâneas já absorvidas pelo público especializado. A sociologia tradicional da arte, por sua vez, se ateve mais a demonstrar a congruência entre formas de organização social e estilos ou temas artísticos do que analisar a inserção social da produção [...] Sem considerar a produção e circulação da obra de arte no meio social, de forma a percebê-la em sua dinâmica, a sociologia da arte trabalhou predominantemente com os resultados (a obra) e não com os processos (Bulhões, 1991, p. 26, grifo nosso).

Assim, esses processos sociais não evidenciados, segundo a pesquisadora, são constituídos por sistemas de arte que se colocam a serviço das elites sociais, como estruturas veladamente institucionalizadas. Tais estruturas, por sua vez, definem aquilo que pode ser considerado uma obra de arte com estimado valor socioeconômico (Bulhões, 2005); ou, ainda, quem pode ser considerado um grande artista e quem não pode. Sobre essa temática, segundo o pesquisador Coli (2008), "não é preciso muito conhecimento para sabermos que Dante é 'maior' ou 'superior' a Casimiro de Abreu, que Benedito Calixto é 'inferior’ a Leonardo, que Bach é o maior de todos os músicos [...], pois trata-se de julgamentos correntes, que parecem óbvios ou tácitos" (p. 13, grifo nosso). Contudo, esses julgamentos omitem, historicamente, os processos de institucionalização da arte. 
Vigotski (2009), por sua vez, parece que não se ateve a essa discussão ${ }^{12}$, pois, apesar de toda a complexidade de sua teoria - na qual fundamentamos os princípios psicológicos e ontológicos que amparam nossa pesquisa - o autor em momento algum questiona a institucionalização da arte (ou os processos de validação da arte) em suas obras mais eminentes acerca desse assunto; Psicologia da Arte, Imaginação e Criação na Infância e Psicologia Pedagógica. A sua preocupação, na realidade, estava na relação entre desenvolvimento humano e arte.

Contudo, em dados momentos, percebemos uma sensibilidade sobre o tema na obra Psicologia da Arte. Por exemplo, Vigotski (1999) defende que tanto as criações populares, quanto as individuais (no caso já apresentado do escritor Púchkin) partem de um mesmo princípio que abarca as dimensões social e histórica. Porém, em outra obra, Imaginação e criação na infância, notamos algumas interpretações que dão margem a conclusões precipitadas quando, o autor, ao defender a importância do meio e das trocas culturais nos processos de criação, afirma:

as classes privilegiadas detêm um percentual incomensuravelmente maior de inventores na área da ciência, da técnica e das artes porque é nessas classes que estão presentes todas as condições necessárias para a criação (Vigotski, 2009, p. 42, grifos nossos).

Intensificando o seu argumento, de que há uma escassez de invenções nas classes sociais menos privilegiadas se comparadas às mais privilegiadas, o autor cita Ribot: "ao comparar pessoas negras com pessoas brancas, povos primitivos com

\footnotetext{
${ }^{12}$ Que não coube, de modo geral, ao seu tempo e ao seu contexto. Pois, conforme apontaremos adiante, na discussão sobre o conceito de cultura popular, a virada do século XIX para o XX é marcada por visões equivocadas sobre a cultura popular (Arantes, 2006; Fernandes, 1989) e, consequentemente sobre as expressões artísticas do 'povo' que, na realidade, sequer eram consideradas artísticas (Bulhões, 2005; Coli, 2008).
} 
civilizados, vê-se que, sendo o tamanho da população o mesmo, a desproporcionalidade no número de inovadores, nos dois casos, é impressionante” (p. 41-42, grifo nosso).

Nesse aspecto, notamos uma lacuna em sua argumentação, pois, em momento algum o autor questiona que: não se trata de menos inventores ou invenções artísticas, científicas etc., mas principalmente de uma omissão (subestimação) das invenções das classes desfavorecidas, dos países desfavorecidos, dos continentes desfavorecidos historicamente pelas lutas e tensões sociais - guerras, saqueamentos, colonizações, imposições ideológicas etc. Em que os negros, que Ribot cita, ocupam grande parte dessa população desprivilegiada.

É fundamental apontarmos isso, pois, ao tratarmos das invenções (artísticas) da cultura popular, veremos que elas se situam, na maioria das vezes, nessas chamadas classes menos favorecidas. Nesse viés, é importante ressaltar que a nossa pesquisa contempla também uma dimensão política que evidencia as bases ideológicas que, até hoje, vigoram e desconfiguram/desvalidam as invenções populares, conforme discutiremos a seguir.

Assim, cabe enfatizar que entendemos a arte tanto como uma necessidade do psiquismo humano (Vigotski, 1999) quanto como uma comunicação ideológica (Bakhtin, 2006), que se constitui pelos mecanismos de sua institucionalização (Bulhões, 1991, 2005). Diante disso, as múltiplas criações artísticas não escapam aos sistemas que, numa sociedade capitalista, continuam ditando as regras e restaurando seus aspectos elitistas, excludentes e dominantes (Lauer conforme citado por Bulhões, 2005). Desse modo, é por via de uma conjuntura extremamente complexa que vemos situados nossos/as os/as brincantes; pois, na maioria das vezes, os/as encontramos, justamente, entre os/as milhares de artistas populares anônimos, invisibilizados por esses grandes sistemas de tão poucos. 


\section{O BRINCAR}

A concepção de que 'brincadeira é coisa de criança' já está incorporada em nosso cotidiano. No campo da psicologia do desenvolvimento, os estudos sobre o brincar têm privilegiado o brincar na infância (Oliveira, 1995; Piaget, 2014; Silva \& Abreu, 2015; Vigotski, 2007, 2009; Wallon, 2007). Historicamente, as variadas pesquisas sobre ludicidade (que envolvem os jogos e o brincar) dão enfoque à criança. Porém, há trabalhos que apontam para a importância do brincar após essa etapa, como é o caso das investigações do psicanalista Winnicott que "a partir dos seus estudos na clínica infantil, defende a tese de que é necessário se estudar o brincar como um fenômeno que ocorre tanto com a criança como com o adulto nas suas formas diferenciadas" (Pedroza, 2005, p. 64). Entretanto, essas pesquisas que evidenciam o brincar para além da infância são pontuais se comparadas ao número de trabalhos que tematizam essa fase - até mesmo Winnicott partiu de observações da clínica infantil.

Para Vigotski (2009), como uma forma de prática social, a brincadeira é também uma "construção de uma realidade nova que responde às aspirações e aos anseios da criança” (p. 17). No contexto infantil, o brincar, inúmeras vezes, satisfaz desejos impossíveis de serem realizados imediatamente, mas que se tornam possíveis por meio da imaginação (Vigotski, 2007).

Além disso, segundo o autor, a brincadeira na infância, baseia-se na necessidade que a criança vivencia de compreensão do universo adulto e da própria realidade. Entretanto, apesar de satisfazer determinadas aspirações da criança, Vigotski não entende a brincadeira somente como uma atividade prazerosa. Brincar, nessa perspectiva, envolve um misto de prazer e desprazer, situando-se no limiar entre a necessidade e o desejo infantil (Silva et al., 2015). 
Pelo brincar as formações inventivas e $\operatorname{simbólicas}^{13}$ são viabilizadas: "os pequenos brincam que são professores, mães-pais, filhos(as), médicos(as), motoristas etc. e, ao mesmo tempo que se apoiam no real (por meio das regras e das generalizações de papéis), efetuam transformações inventivas no plano simbólico" (Silva, Costa \& Abreu, 2015, p. 117). Ao brincar, a criança se apropria das regras e dos valores sociais que a circundam (Vigotski, 2007), efetuando transformações fundamentais para o seu desenvolvimento psicológico. Petrova (conforme citada por Vigotski, 2009) diz que "a brincadeira é a escola da vida para a criança, [uma] forma efetiva de superar o mundo" (p. 99) - em outras palavras, de buscar entendê-lo, interpretá-lo, elaborá-lo, transformá-lo e ampliá-lo.

Nesse ponto, percebemos uma relação profunda entre o brincar e a arte, principalmente no que diz respeito à discussão, apontada anteriormente, sobre a dimensão emancipadora da experiência estética/artística; como algo que também transforma e supera a pobreza e a fome humana (Vigotski, 2010), que humaniza o "homem" e dá sentido a sua experiência. Segundo Silva, Costa e Abreu (2015), "a analogia entre o brincar e o teatro", por exemplo, "é bastante oportuna" (p. 120).

Nas ações lúdicas, como os jogos de $f a z$ de conta, as crianças assumem diferentes papéis e, como apontamos, brincam de ser mãe, pai e também bicho, avião, flor etc. Nessa assunção de papéis, "sua atenção volta-se para uma lógica do acontecimento imaginário, em que o uso de objetos substituídos (brinquedos) e a representação de papéis estão presentes na manutenção da consciência do tema a ser encenado" (Silva, Costa \& Abreu, 2015, p. 121). Por essa via, enfatizamos a dimensão coconstitutiva da imaginação, no brincar e na arte.

\footnotetext{
${ }^{13}$ Essas formações partem da (e promovem a) própria realidade. Aqui lembramos a dimensão dialética discutida no capítulo 1, ao abordarmos a psicologia concreta, além das considerações sobre a imaginação/fantasia e o real, no capítulo 2.
} 
Sobre isso, notamos ainda uma característica bastante interessante, apontada por Vigotski (2009), acerca do exagero nas ações inventivas humanas. Para o autor, as crianças possuem uma imensa paixão pelo exagero. Contudo, o pesquisador também reforça que qualquer ação inventiva (no brincar, na arte, na ciência etc.), da criança ao adulto mais velho, é regida pelo exagero. Segundo ele, "exageramos porque queremos ver as coisas de forma exacerbada, porque isso corresponde à nossa necessidade, ao nosso estado interno" (Vigotski, 2009, p. 37).

Essa discussão é fundamental para nossa pesquisa. Adiante, veremos que um dos argumentos que, historicamente, vem desvalidando as múltiplas expressões (estéticas) populares embasa-se justamente na concepção de que elas exageram. Ora, apontamos de antemão que esse argumento não deveria ser, em hipótese alguma, um quesito para o depreciamento das criações populares — pois, conforme Vigotski (2009) argumenta, o exagero perpassa todas as ações inventivas (criações) humanas. Assim, tanto o carnaval quanto a matemática e a religião exageram.

Logo, o brincar de faz de conta da criança também abarca essa lógica do exagero, fundamental nas suas criações. Nele, a criança assume distintos papéis, conta histórias extraordinárias (para além da vida ordinária) e vivencia mudanças

[...] de lugar, de posição social — importante para o exercício de alteridade [...] - e abre a possibilidades ao desenvolvimento da capacidade de afetar, de ser afetado e de criar. Nesse processo, a criança torna-se ativa em meio às emoções que vivencia intensamente nessa fase, podendo reconhecê-las e, então, transformá-las. (Magiolino, 2015, p. 134, grifos nossos) 
Nesse vivenciar a alteridade pelo brincar, a criança (como ser social) constitui a própria subjetividade, com base em experiências (est)éticas ${ }^{14}$ viabilizadas pelo seu corpo, na relação com outros corpos (Magiolino, 2015) — corpo, este, que é "memorioso, sensível, impregnado de signos e sentidos, material semiótico e aberto ao mundo, ao outro [...]” (Magiolino, 2015, p. 149). Essa experiência estética - de vivenciar a alteridade encarnada no próprio corpo — é essencial no desenvolvimento humano e diz respeito, principalmente, à raiz dramática (Smolka, 2009) da nossa própria constituição, observada aqui tanto no brincar (jogos de faz de conta) quanto na arte (criação teatral).

Nesse contexto, o conceito de drama, abordado por Vigotski (2000), vai além da definição artística ou literária, mais recorrente, e adentra a noção psicológica do desenvolvimento humano: "a dinâmica da personalidade é o drama" (p. 35). Delari Junior (2011) alerta que o termo possui diferentes sentidos na perspectiva vigotskiana.

Ao focarmos a dimensão do brincar infantil, o drama pode ser entendido principalmente como a possibilidade de vivenciar o "lugar do outro" (Smolka, notas comentadas em Vigotski, 2009, p. 99). Trata-se de um jogo de papéis sociais que se dá por meio da descentralização de si mesmo, pelo exercício da alteridade (Magiolino, 2015), conforme apontamos.

Smolka (notas comentadas em Vigotski, 2009) afirma, ainda, que na raiz do drama encontramos a brincadeira, e vice-versa. Nesse sentido, entendemos que, se o drama é a dinâmica da personalidade humana e em sua raiz a brincadeira está contida, o brincar é, então, uma forma de expressão e de constituição humana que não abarca apenas a infância. Por esse via, podemos argumentar que o brincar é uma necessidade ontológica que se estende ao longo de toda a nossa trajetória.

\footnotetext{
${ }^{14}$ Termo da pesquisadora que problematiza "a dimensão ética e estética das emoções humanas" (Magiliolino, 2011, 36).
} 
Esse argumento dialoga profundamente com as proposições discutidas no recente documentário brasileiro Tarja branca: a revolução que faltava, dirigido por Rhoden (2014). No filme, várias pessoas famosas e anônimas (músicos, atores, escritores, psicólogos, professores, feirantes etc.) dão depoimentos sobre a importância do brincar. Entre elas, enfatizamos inicialmente as colaborações do psicanalista Goldenberg, do etnomusicólogo Ikeda e das professoras Pereira e Hortello.

Segundo Goldenberg, no atual contexto capitalista — de venda, lucro e trabalho excessivo —, o brincar passou a ser situado como uma atividade ociosa e, portanto, não séria e infantilizada. Já o mundo dos negócios (negação do ócio), seria uma espécie de emblema dos sujeitos seriamente engajados na atual dinâmica do trabalho. O psicanalista opõe-se a tal perspectiva e enfatiza que brincar, em sua raiz, é uma atividade extremamente séria, pois o próprio conceito de seriedade está, na realidade, atrelado à noção de levar as coisas até as últimas consequências, de estar focado: “isso é sério! E isso a criança faz!”. Ikeda, por sua vez, discute que, no universo adulto, o que encontramos é muito mais uma suposta seriedade, bastante nociva à saúde humana.

Tais perspectivas nos permitem entender que brincar como as crianças — isto é, com a devida seriedade que as crianças atribuem às suas brincadeiras — é uma necessidade humana extremamente importante e profundamente séria. Reforçamos que essa necessidade se estende ao longo da vida.

Assim, deixar de brincar é violentar a capacidade de um sujeito "ser por inteiro", como afirma a professora Pereira, no documentário. De forma semelhante, para a educadora Hotello, "não brincar é se diminuir". Logo, percebemos que esses atos de diminuição (violência), na contemporaneidade, são bastante exercidos em prol do 
funcionamento da ordem social, sendo a seriedade nociva uma imposição fundamental para que o sistema possa se sustentar.

Entretanto, justamente pelo brincar constituir a própria essência da vida humana, apesar de todas as tentativas de aniquilação da sua raiz — principalmente com o ingresso na vida adulta —, podemos encontrar pessoas que permanecem/resistem brincando após a infância. Esse brincar, no Brasil, pode ser observado nas manifestações artísticas da chamada cultura popular. Nesse caso, veremos, que brincar torna-se uma espécie de profissão (ofício de vida), denominada de brincante.

\subsection{Os/As brincantes da cultura popular}

É no cavalo marinho, no mamulengo, no bumba meu boi, no frevo, no reisado, entre outras manifestações populares, que brincantes dedicam suas vidas para colocar, todos os anos, suas brincadeiras nas ruas (atualmente também nos palcos, teatros etc.) das mais diversas cidades. O termo brincante é definido pelo "[...] próprio modo de se expressar das pessoas que pertencem a esse universo [da cultura popular] por se autodenominarem brincantes e utilizarem expressões [por exemplo] como 'vamos brincar Cavalo Marinho"” (Lewinsohn, 2008, p. 26).

Nesse caso, ao brincar cavalo marinho, o brincante coloca sua brincadeira na rua. A brincadeira, por sua vez, é parte do brinquedo (cavalo marinho). Assim, o brinquedo abrange toda a extensão da manifestação. Novamente exemplificando, quando um brincante borda sua roupa, ele está construindo o seu brinquedo. Ao vestir a roupa e assumir uma figura (personagem), ele está na brincadeira propriamente dita.

Além disso, o termo brincar diferencia-se de conceitos como apresentar e estrear (Barroso conforme citado por Lewinsohn, 2008), bastante observados nas atividades teatrais. Assim, os/as brincantes da cultura popular convocam o público para 
brincar junto, e não para assisti-los. Logo, percebemos que a fronteira entre brincantes e público se esvai nesse contexto, e a própria distinção entre quem é e quem não é brincante torna-se extremamente frágil, pois, de certo modo, na brincadeira todos/as viram brincantes.

Antônio Santos, capitão de uma brincadeira de congada em Minas Gerais relata, também no documentário Tarja branca, que "a [minha] brincadeira tem que abrir a brincadeira do outro!" (Rhoden, 2014). Assim, a brincadeira exige uma troca, uma abertura, de ambos os brincantes (convidador e convidado), de modo que, para brincar efetivamente, é necessário se abrir e ser aberto.

Nesse viés, contudo, identificamos uma problemática inicial para a nossa pesquisa: se todos podem tornar-se brincantes mediante um convite aceito, como podemos definir um/a brincante? $\mathrm{O}$ que o/a caracteriza e o/a que o distingue? Para refletir sobre essas questões, acreditamos que a discussão sobre o conceito de cultura popular é fundamental, pois, conforme apontamos, na maioria das vezes identificamos os/as brincantes justamente no contexto dessa cultura chamada popular.

\subsection{Cultura popular: discutindo o conceito}

O pesquisador francês Chartier (1995) inicia seu artigo sobre a noção de cultura popular afirmando que essa “[...] é uma categoria erudita” (p. 179). De fato, o termo cultura popular foi inicialmente categorizado por pesquisadores acadêmicos e não pelos próprios sujeitos que, segundo tais pesquisadores, pertenciam à cultura popular (Brandão, 2009; Chartier, 1995). Na realidade, esse conceito ainda está longe de ser claramente delimitado pelas ciências humanas, pois as definições sobre o que é popular e o seu suposto contrário, erudito, são tênues (Arantes, 2006). A própria origem histórica do termo cultura popular é de difícil compreensão (Chartier, 1995). 
Porém, numa tentativa de contribuir para a sua complexa delimitação histórica, Chartier (1995) aborda o conceito em questão com base em duas grandes vertentes: a) cultura popular como um sistema autônomo e alheio à cultura letrada e b) cultura popular como a afirmação de relações de dominação, na qual se enfatizam as deficiências e carências desta em relação a uma suposta - e oposta - cultura dominante, a erudita.

Essas duas vertentes, para Chartier (1995), decorreram de acontecimentos na Europa Ocidental, por volta de 1.200, de ordem teológica, científica e filosófica. Tal período ficou marcado por expressões sociais que isolavam "a cultura erudita das tradições folclóricas, censurando as práticas doravante tidas como supersticiosas ou heterodoxas, e constituindo como um objeto posto à distância, sedutor e temível, a cultura dos humildes" (Chartier, 1995, p. 181, grifos nossos).

A partir dessa perspectiva histórica, formaram-se graves rupturas socioeconômicas que caracterizaram parte da população como popular, diferenciando o universo oficial, formal e erudito (da instrução, leitura, religião e ciência) do universo alternativo, informal e popular (do iletrado, supersticioso, temível, sedutor, pecaminoso e humilde). Dessa maneira, percebemos que o conceito cultura popular, desde sua origem, comporta os confrontos sociais, as lutas de classes.

Em outras pesquisas (Arantes, 2006; Brandão, 2009; Fernandes, 1989), que investigaram os desdobramentos do conceito a partir do século XIX, também encontramos essa dimensão conflituosa das lutas sociais. Estudiosos como Fernandes (1989) e Brandão (2009) abordaram tal questão, por exemplo, pela discussão de outros dois conceitos, caros a nossa pesquisa: a exotização e a romantização da cultura popular. 
Segundos esses autores, as noções exótica e romântica sobre a cultura popular têm herança no positivismo e evolucionismo emergentes no século XIX, principalmente nas ciências sociais, e foram reforçadas pelos estudos folcloristas. Como projeto da burguesia europeia, essas concepções apresentavam uma percepção linear e gradual do desenvolvimento cultural, em que alguns pequenos grupos possuíam uma cultura superior, enquanto a maioria possuía uma cultura inferior ou, até mesmo, era considerada sem cultura, inculta (Arantes, 2006).

Nessa condição, a cultura popular (ou dos incultos) era abordada: a) como algo alheio e deficiente, premissas da noção exótica que a situa em um baixo patamar no jogo social das hierarquizações e; b) como um sistema autônomo e autossuficiente, encontrado na visão romântica, que prega a inexistência de conflitos e de complexidade social (Arantes, 2006). De certo modo, essas duas perspectivas caminham juntas e se retroalimentam.

No Brasil, a apropriação do conceito de cultura popular emergiu no final do século XIX, difundido principalmente por intelectuais folcloristas, antropólogos, sociólogos, educadores e artistas, que visavam a uma identidade cultural nacional (Abreu, 2003). Segundo a pesquisadora Abreu (2003), o termo cultura popular foi amplamente utilizado de forma contraditória: por um lado, representando a não modernidade (o interior, o regional) e, por outro, representando o futuro do país.

Entretanto, no início dos anos 1960, o conceito de cultura popular foi ressignificado pelos Movimentos de Cultura Popular (MCPs), que tiveram em Paulo Freire um de seus maiores representantes. Apesar de terem sido abafados pela ditadura militar, os MPCs apresentaram um sentido diferente ao termo, primeiro porque ele deixou de ser apenas utilizado por uma suposta elite cultural e passou a ganhar força 
entre grupos de trabalhadores/as oprimidos/as; segundo porque a cultura popular tornou-se uma expressão política, de luta das massas (Brandão, 2009).

Nesse período, o caráter até então folclórico vinculado ao conceito ganhou outra dimensão, centrada nas contradições das lutas de classes e na noção de trabalho de inspiração marxista. A cultura popular se tornou, então, uma forma de resistência a uma suposta ordem social vigente (Brandão, 2009). Logo, o termo cultura popular passou a abarcar também uma dimensão denunciativa dessa ordem (Gullar, 1983).

Em tal conjuntura sociopolítica, novos conceitos foram elaborados, como educação popular e educador popular. Porém, o grande diferencial emergente foi que esses conceitos, agora, partiam da fala (das expressões) dos próprios sujeitos; estes passavam a se autodenominar educadores/as populares, pertencentes, portanto, ao universo mais amplo dos MPCs. Nesse âmbito, “a educação trava uma relação dialética com a cultura" (Freire, 1983, p. 113, grifos nossos), opondo-se aos assistencialismos oferecidos pelo Estado. Por esse viés, Freire (1983) ressaltou a importância do fazer com o povo (que implica luta, resistência e conscientização política) versus fazer para o povo (que implica conformismo e assistencialismo governamental).

Feita essa contextualização, percebemos que os termos importantes neste estudo, brincante e cultura popular, possuem uma aproximação ampla com os MCPs, justamente por sugerirem um caminho de ressignificação, apropriação e autonomeação. Nessa perspectiva, não é mais apenas um outro (acadêmico, erudito ou governante) que determina quem é brincante (e o que é cultura popular), mas, principalmente, um eu (sujeito) que se autodenomina brincante, pertencente ao amplo universo da cultura popular.

Contudo, não podemos ser ingênuas em relação às múltiplas apropriações desse conceito, muitas vezes indevidas, que essa liberdade de autodenominação inclui e 
aos riscos que ela nos oferece. Atualmente, vários grupos de artistas se autodenominam (brincantes) populares quando, por exemplo, necessitam se identificar em um contexto histórico-cultural mais amplo, como o das políticas públicas e o dos grandes eventos culturais. Portanto, definir quem são os/as verdadeiros/as brincantes/artistas populares consiste em uma tarefa árdua, principalmente, quando há fomentos governamentais específicos para o contexto da cultura popular ${ }^{15}$.

Entretanto, nosso foco não é a discussão de eventuais medidas para identificar e mapear quais brincantes merecem, ou não, apoios governamentais ou de quaisquer outras instâncias - que, devemos enfatizar, ainda são extremamente escassos no nosso país. O que nos interessa, nesta pesquisa, é a investigação central sobre a produção de sentidos da/na constituição do/a brincante, visto que ser brincante, conforme elucidamos, ainda é um caminho socialmente desvalorizado e, como veremos, complexo.

A partir dessa inquietação central, abordaremos algumas contribuições teóricas que nos auxiliam a refletir sobre o assunto. Dividimos essas contribuições em dois itens: a) brincadeiras: resistência e luta e; b) brincadeiras e festejos populares: contribuições de Mikhail Bakhtin.

\subsubsection{Brincadeiras: resistência e luta}

A discussão sobre o conceito de cultura popular e o seu desdobramento a partir dos MCPs nos leva ao argumento de que ser brincante implica também uma ação política e, entre outras características, brincar é um ato constante de resistência e de luta. Isso porque as manifestações oriundas do universo popular orbitam em uma lógica

\footnotetext{
${ }^{15}$ Por exemplo, em editais do Fundo de Apoio à Cultura (FAC) específicos para as manifestações "folclóricas", "artesanais" etc.
} 
não apenas diferente, mas divergente da lógica do sistema hegemônico, desde as suas raízes históricas.

Essa divergência resultou (e ainda resulta) em uma profunda desvalorização, desvalidação e desprestígio dos saberes e fazeres populares. Atualmente, por exemplo, ao abordarmos especificamente as manifestações relativas à estética/arte popular, nos deparamos com uma série de ações públicas e privadas que desconfiguram e descaracterizam tais expressões.

Em relação a essa questão da estética/arte, o antropólogo Carvalho (2005) nos alerta sobre a chamada espetacularização da cultura popular. Segundo o autor, a espetacularização consiste em ações que inserem as manifestações populares em tempos e espaços compactadores, pré-determinados por outro agente, alheio e indiferente às manifestações. Nesse contexto, o outro agente só aprecia e autoriza a entrada de manifestações desse cunho em seus espaços, quando estas são moduladas em outros formatos, como sinalizamos, compactadores (Carvalho, 2005).

Em outra pesquisa, mais recente, Carvalho (2010) enfatiza ainda que, ao lado da espetacularização das culturas populares na América Latina, encontra-se também a canibalização das mesmas:

os dois termos [canibalização e espetacularização] procuram exprimir a percepção e a consciência de que as culturas populares estão sendo expostas a um movimento crescente e contínuo de invasão, expropriação e predação, conectado basicamente com a voracidade das indústrias do entretenimento e do turismo e também com a cooptação de artistas populares por parte de políticos regionais populistas (Carvalho, 2010, p. 41).

No que diz respeito às ações políticas e governamentais brasileiras, a reconhecida desvalorização da cultura popular fez com que, em 2010, o governo Lula 
lançasse um plano específico de atuação nessa esfera: o Plano Setorial para as Culturas Populares (Brasil, 2010). Nesse documento, é discutida a invisibilidade das manifestações populares: "são tantas e incontáveis, desconhecidas da sociedade e até [há] pouco tempo invisíveis para o Estado" (Brasil, 2010, p. 7).

Entretanto, seria muito arriscado argumentar que a sociedade brasileira, como um todo, ignora a existência dessas incontáveis manifestações que emergem dela própria. Na realidade, é uma parcela social que desconhece as expressões populares e que, conforme sinaliza o documento, é incorporada principalmente pelo Estado e, acreditamos, por outras esferas públicas e privadas, detentoras de grande poder econômico. E é, justamente, diante dessa parcela social que as culturas populares (desconhecidas) se apresentam, em sua maioria, na hora e no espaço demarcado da espetacularização ${ }^{16}$.

Recentemente, encontramos um exemplo oportuno sobre essa discussão no catálogo da exposição Maracatu Rural: A Magia do Canavial, em que os autores Vicente e Vicente (2013) relatam a dificuldade enfrentada pelos/as brincantes de maracatu. Eles/as são comparados/as com loucos por todo o esforço que fazem para transformar a brincadeira (o maracatu) em realidade: para vivenciá-la, homens e mulheres viram noites bordando, fazem fiado nos armarinhos, arrumam dinheiro para o ônibus, mesmo sendo, a maioria, pessoas sem muito poder aquisitivo (Vicente \& Vicente, 2013). Contudo, após todo esse trabalho intenso, que envolve um misto de “correria, gritaria, preocupação, vibração, orgulho, amor, paixão e ansiedade [...], o prefeito ou a prefeita [...] ignora tudo isso e paga míseros 100 reais pela apresentação" do grupo inteiro (p. 2, grifo nosso).

\footnotetext{
${ }^{16}$ Aqui é importante destacar que espetacularização é diferente de espetáculo e de espetacularidade.
} 
No exemplo acima, fica evidente que o outro agente (o prefeito ou a prefeita) desconhece/ignora a brincadeira em sua complexidade e paga conforme o seu desconhecimento. Além disso, encontramos, na citação, uma alteração conceitual interessante, que diz respeito ao termo apresentação (em vez de brincadeira). Assim, se nas brincadeiras populares qualquer pessoa pode tornar-se brincante, na atual lógica da espetacularização é imposta, aos/às brincantes, uma moldura limitadora de suas expressões: a apresentação (apresentador e plateia).

Outro exemplo instigante sobre a desvalorização da arte popular é encontrado no recente trabalho musical do brincante Herbert Lucena ${ }^{17}$ (2011), intitulado Não me peçam jamais que eu dê de graça tudo aquilo que eu tenho pra vender ${ }^{18}$. Na obra, que traz uma série de parcerias com mestres e artistas brincantes, Lucena apresenta músicas que tecem uma crítica à atual condição dos/as artistas populares no Brasil. Assim, na primeira faixa do $\mathrm{CD}$, que tem o mesmo nome da obra, a letra da canção alerta:

eu nasci pra cantar coco e ciranda, e forró que tem boa freguesia. Mas nas rádios não toco noite e dia, pelo jeito esse cartel comanda. Escolhendo quem cresce e quem não anda. Porém minha construção não vou ceder, nem tão pouco de bandeja oferecer, aos que não bebem da minha cachaça. Não me peçam jamais que eu dê de graça, tudo aquilo que eu tenho pra vender. Não me peçam jamais que eu dê de graça, tudo aquilo que eu tenho pra viver! (Lucena, 2011, faixa 1, grifos nossos).

\footnotetext{
${ }^{17}$ Nascido em Recife (1965), além de músico, Lucena é produtor de diversos artistas e bandas da cultura popular nordestina. Seu primeiro trabalho solo foi lançado em 2004 (Na pisada desse coco). Em 2011, Lucena lançou seu segundo trabalho, Não me peçam jamais que eu dê de graça tudo aquilo que eu tenho pra vender, contendo críticas afiadas à desvalorização da cultura popular no Brasil. Este mesmo trabalho lhe rendeu quatro indicações e três premiações no $23^{\circ}$ Prêmio da Música Brasileira, em 2012. [Informações retiradas do site do artista, https://soundcloud.com/herbertlucena, em julho de 2015].

${ }^{18} \mathrm{Na}$ obra, o artista se apropria da famosa frase da atriz Cacilda Becker [1921-1969], "não me peça para dar de graça a única coisa que tenho para vender", dita durante uma entrevista.

Ver http://www.old.pernambuco.com/ultimas/nota.asp?materia=20120519124438. Acesso em julho de 2015.
} 
No trecho da música, notamos que Lucena critica o contexto (mercado) profissional artístico, que escolhe "quem cresce e quem não anda", reivindicando a valorização do seu trabalho de vida. O artista enfatiza, assim, a falta de reconhecimento, atrelada à desvalorização do seu trabalho, por aqueles que "não bebem da minha [sua] cachaça".

Percebemos, contudo, que tanto no exemplo de Lucena como no do grupo de maracatu há uma crítica profunda às construções e condições de vida (trabalho) dos/as brincantes populares. Os relatos se relacionam também com a discussão apresentada, no capítulo anterior, sobre os sistemas de arte (Bulhões, 2005). Nesse contexto, notamos que a cultura popular, há séculos, tem permanecido à mercê de uma conjuntura social e política hegemônica que não a compreende e não a valoriza em sua complexidade.

Porém, contraditoriamente, mesmo diante da atual conjuntura — que favorece a aniquilação das inúmeras manifestações populares —, os brinquedos persistem, inovam-se e continuam a encorajar pessoas a se tornarem brincantes de profissão e de vida. Nesse cenário, identificamos algo valioso, que está além das relações mercadológicas de compra e venda, outra face da moeda: vibração, orgulho e paixão (Vicente \& Vicente, 2013).

Assim, brincar não pode ser resumido aos atos de resistência, embora essa dimensão seja profundamente relevante para as expressões populares. Em uma tentativa de entender outros aspectos motrizes que impulsionam os/as brincantes a optarem por esse trajeto de vida, recorreremos, a seguir, aos estudos de Bakhtin (2008) sobre as expressões estéticas populares. 


\subsubsection{Brincadeiras e festejos populares: contribuições de Mikhail Bakhtin}

Apesar de não ter utilizado especificamente o termo brincar (ou brincadeira), Bakhtin desenvolveu um importante estudo sobre a cultura (estética) popular em sua obra A cultura popular na Idade Média e no Renascimento: o contexto de François Rabelais. Em alguns desdobramentos interpretativos, entendemos que as múltiplas reflexões sobre as manifestações estéticas do universo popular apresentadas pelo autor — principalmente os festejos em praças públicas (como o carnaval) — são expressões dessa dimensão do brincar que investigamos atualmente.

A noção de cultura popular, segundo Bakhtin (2008), era bastante equivocada, em seu tempo, graças às concepções oriundas do período pré-romântico e romântico. Para o autor russo, especialmente a cultura cômica popular (o riso popular) havia sido mal interpretada, quando não desconsiderada, por grande parte dos estudiosos do tema. Contrariando tal corrente de estudiosos, Bakhtin (2005) entendeu a cultura popular como um universo rico, amplo e complexo; assim, buscou reverter a visão romântica sobre a cultura popular vigorante até então.

Para tanto, o pesquisador analisou a obra literária de François Rabelais [14941553], justamente por este ser tido como porta-voz da cultura popular cômica de seu tempo, entre a Idade Média e o Renascimento. Rabelais, segundo Bakhtin (2008), atingiu grande aprovação pelas classes populares em virtude de suas sátiras politizadas, subversivas, que abarcavam um caráter não oficial da vida:

o mundo infinito das formas e manifestações do riso opunha-se à cultura oficial, ao tom sério, religioso e feudal da época. Dentro da sua diversidade, essas formas e manifestações — as festas públicas e carnavalescas, os ritos e cultos cômicos especiais, os bufões e tolos, gigantes, anões e monstros, palhaços de diversos estilos e categorias, a literatura paródica, vasta e 
multiforme, etc. - possuem uma unidade de estilo e constituem partes e parcelas da cultura cômica popular, principalmente da cultura carnavalesca, una e indivisível. (Bakhtin, 2008, p. 3, grifos nossos)

O caráter não oficial (exterior à Igreja e ao Estado) é compreendido principalmente pela sua dimensão cômica — pelo riso popular, um elemento central na discussão, conforme já sinalizamos. O autor argumenta ainda que existe uma unidade de estilo nas manifestações populares, dada justamente pela comicidade comum a essas expressões.

Desse modo, os festejos em praças públicas aconteciam (e notamos que muitos ainda acontecem) em paralelo a um mundo oficial ${ }^{19}$. Esse paralelismo, por sua vez, é explicado com base no conceito de segundo mundo ou segunda vida. Bakhtin (2008) afirma: "o carnaval é a segunda vida do povo, baseada no princípio do riso. É a sua vida festiva. A festa é a propriedade fundamental de todas as formas de ritos e espetáculos cômicos da Idade Média” (Bakhtin, 2008, p. 7, grifos nossos).

Para o autor, as festas públicas possibilitavam outra dimensão da própria experiência humana (segunda vida). Assim, durante essas folias, abria-se a possibilidade de encarnar ou vestir uma segunda pele, completamente contrária à vida oficial/ordinária. Mas é interessante perceber que, no período e contexto estudados por Bakhtin (Idade Média e Renascimento), a maioria da população vivenciava (encarnava) tanto uma condição oficial como uma não oficial. Festejos populares, como o carnaval, por exemplo, possuíam tamanha relevância social que chegavam a durar três meses (Bakhtin, 2008).

Nessas longas celebrações de natureza cômica, festa, arte e vida se confundiam profundamente: “[...] o carnaval não é de maneira alguma a forma puramente artística

\footnotetext{
${ }^{19}$ Argumento que dialoga profundamente com os estudos sobre resistência e luta, já apresentados.
} 
do espetáculo teatral" (Bakhtin, 2008, p. 6), indo além da própria arte. Assim, para o pesquisador, as expressões estéticas populares, como o carnaval, permeavam uma tênue fronteira entre a vida e a arte.

Segundo Bakhtin (2008), no carnaval se desconstruía o palco e a plateia, as relações de poder se horizontalizavam, anulavam-se as fronteiras espaciais, penetrandose "temporariamente no reino utópico da universalidade, liberdade e abundância" (p. 8). Assim, o princípio universal (de renovação) e libertador desse festejo abarcava uma forma de relação e comunicação familiar, com expressões dinâmicas, ativas e mutáveis.

A comunicação carnavalesca era livre e possibilitava interações entre as pessoas que, no contexto oficial da vida, jamais ocorreriam (Bakhtin, 2008). Nesse sentido, havia uma comunicação mais franca, sem as restrições decorrentes das normas de etiqueta dos dias comuns:

[...] durante o carnaval nas praças públicas a abolição provisória das diferentes barreiras hierárquicas entre as pessoas e a eliminação de certas regras e tabus vigentes na vida cotidiana criavam um tipo especial de comunicação ao mesmo tempo ideal e real entre as pessoas, impossível de estabelecer na vida ordinária. (Bakhtin, 2008, p. 14)

Dessa forma, no carnaval "o indivíduo parecia dotado de uma segunda vida que lhe permitia estabelecer relações novas, verdadeiramente humanas, com os seus semelhantes. A alienação desaparecia provisoriamente" (Bakhtin, 2008, p. 9, grifos nossos). Contudo, essa segunda vida ou segunda pele desalienada e possibilitada pelo carnaval, era, para o autor, profundamente concreta, corporal. Possuía, assim, forma própria: a estética grotesca.

Para Bakhtin (2008), conforme evidenciamos, a partir da metade do século XIX, ocorreu uma espécie de desvirtuamento dos festejos populares e, como 
consequência, da cultura popular. Segundo o autor, essa incompreensão sobre o campo decorreu de uma vulgarização da estética grotesca. Essa estética, da qual os festejos populares eram (e continuam sendo) porta-bandeiras ou porta-vozes, foi negativada pelas elites, e a sua complexa essência tornou-se incompreendida (Bakhtin, 2008). Assim, o autor russo esclarece que a verdadeira natureza ou essência do grotesco é a expressão da plenitude contraditória e dual da vida, que contém a negação e a destruição (morte do antigo) consideradas como uma fase indispensável, inseparável da afirmação, do nascimento de algo novo e melhor. (Bakhtin, 2008, p. 54)

A estética grotesca assume, portanto, a condição dual da experiência humana, em que coexistem os aspectos sérios e cômicos do mundo: "grosserias e elogios são dois aspectos de um mesmo mundo bicorporal" (Bakhtin, 2008, p. 172). Simultaneamente, é nessa visão dual que se afirma uma concepção unitária do mundo. O grotesco é um "grande e único estilo" (Bakhtin, 2008, p. 53) que agrega os aparentes polos distintos da vida.

Ainda segundo Bakhtin (2008), na estética grotesca ocorre uma espécie de rebaixamento, em que elementos cósmicos, como o espírito, são rebaixados (ou contraditoriamente elevados) a mesma dimensão do corpo e da carne. Assim o corpo é complexo, ideal e abstrato, ao mesmo tempo que é extremamente básico e material, a sua dimensão biológica (comer, beber, defecar, urinar etc.) é tão importante quanto a cósmica (espiritual, ritualística). Logo, durante um enterro, por exemplo, paralelamente se chorava pelo defunto e o ridicularizava (Bakhtin, 2008).

Outro ponto fundamental é que o corpo grotesco triunfa na exuberância e abundância. Assim, essa estética, observada na obra rabelaisiana, abarca imagens exageradas do corpo, em que "a lógica interna de todos esses exageros é [...] a lógica do 
crescimento, da fecundidade, da superabundância" (Bakhtin, 2008, p. 55). As imagens grotescas contrapõem-se ao corpo individual e egoísta da burguesia, constituindo um corpo coletivo, dual e indivisível, conforme discorremos.

O corpo popular, por sua vez, contempla a vida, a morte, a terra, os astros, os humanos, os animais, as plantas etc. Nele, a carne (a matéria de forma mais ampla) possui uma força fecunda e regeneradora e é sempre uma carne incompleta, eternamente criada, recriada e criadora:

na realidade, a função do grotesco é liberar o homem das formas de necessidade inumana em que se baseiam as ideias dominantes sobre o mundo. O grotesco derruba essa necessidade e descobre seu caráter relativo e limitado [...]. O riso e a visão carnavalesca do mundo, que estão na base do grotesco, destroem a seriedade unilateral e as pretensões de significação incondicional e intemporal e liberam a consciência, o pensamento e a imaginação humana, que ficam assim disponíveis para o desenvolvimento de novas possibilidades. (Bakhtin, 2008, p. 43, grifos nossos)

Percebemos que tal estética ambivalente e incompleta não possui espaço nas atuais elites canônicas egoístas e fragmentadas/partidas, pois a natureza grotesca é, em si, anticanônica (Bakhtin, 2008). Contudo, acreditamos que as suas raízes grotescas da ambivalência, do inacabado e do anticanônico - ainda vigoram em nossos tempos, isso porque elas se reinventam, justamente, nas bases comuns da própria experiência humana $^{20}$. Conforme elucida Bakhtin (2005), a estética grotesca libera o "homem" das formas de necessidade inumana.

\footnotetext{
${ }^{20}$ Que considera a necessidade ontológica do "homem" de objetivar-se enquanto humano, como discutimos no capítulo 1 .
} 


\subsection{Delimitação do estudo: psicologia da arte e cultura popular, duas questões periféricas}

Com base nas contribuições apontadas sobre o conceito de cultura popular, ressaltamos a importância de elucidar que ainda existem incompreensões, históricas e sociais, acerca desse universo; seja pelo desvirtuamento da estética grotesca, como apontou Bakhtin (2008), seja pela espetacularização (Carvalho, 2005), seja ainda pelo seu caráter de resistência e denúncia (Arantes, 2006; Brandão, 2009, Chartier, 1995; Fernandes, 1989; Freire, 1983; Gullar, 1983).

Diante disso, percebemos ainda a necessidade de investir em estudos que tracem um olhar mais sensível sobre o campo. Nessa conjuntura, lançamos uma pesquisa que se debruça nesse universo estético popular e enfatiza a importância do brincar para além da infância, em um diálogo profundo com o campo da psicologia da arte, de base materialista, histórica e dialética, conforme argumentamos.

Ao trilhar esse caminho investigativo, notamos que pesquisas recentes traçam reflexões valiosas sobre o campo dinâmico da arte popular: seus/suas brincantes, brinquedos e brincadeiras. Contudo, encontramos essas pesquisas em áreas que não abordam especificamente a psicologia do desenvolvimento (histórico-cultural), aproximando-se mais da antropologia e das artes cênicas, como é o caso da etnocenologia.

Em tal vertente, encontramos, por exemplo, os trabalhos de Lewinsohn (2007, 2008), que investigam a figura do Mateus na brincadeira do cavalo marinho, em Pernambuco. Nesse brincar, a autora relaciona os gestos do trabalho cotidiano (de cortador de cana-de-açúcar) do brincante que põe a figura ${ }^{21}$ do Mateus, com os gestos desenvolvidos na própria brincadeira pela figura. $\mathrm{Na}$ pesquisa, a autora investiga as

\footnotetext{
${ }^{21}$ Ao contrário de encenar ou interpretar um dado personagem, os/as brincantes alegam botar a figura.
} 
qualidades do brincante popular, visando a um aprimoramento dos treinos dos/as atores/atrizes do teatro de rua.

Já a pesquisa de Gomes (2007), também relacionada à etnocenologia, discute o lúdico e o ritual nas tradições culturais da Ilha de Itaparica, como os afoxés. Nesse contexto, a autora apresenta reflexões importantes sobre a memória do corpo nas manifestações tradicionais.

Contudo, ainda são escassas as pesquisas no campo da psicologia históricocultural que investiguem a questão da arte como um problema central se comparadas às pesquisas em outras áreas, como na educação, conforme apontam Barros, Camargo e Rosa (2011). Assim, se a arte já é um problema mais periférico ou quase nulo nesse campo de pesquisa, concluímos que a arte popular é ainda menos contemplada como questão prioritária de investigação. Nesse sentido, enfatizamos a relevância deste trabalho por, justamente, adentrar um território pouco explorado na psicologia. Além disso, também ressaltamos o seu caráter político, que visa contribuir para a desconstrução das noções equivocadas que ainda vigoram sobre a cultura e arte popular, principalmente na educação formal (Freire, 1996), na qual a universidade se inclui.

Para tanto, fizemos uma pesquisa de campo com os/as brincantes do grupo $\mathrm{Seu}$ Estrelo e o Fuá do Terreiro. O grupo, conforme apontamos na apresentação deste trabalho, integra uma série de ações artísticas (teatro, música, dança, literatura etc.), compondo um cenário rico, dinâmico e coerente para a realização da nossa pesquisa. Porém, devido a toda essa diversidade, traçamos um delineamento mais específico e viável aos limites deste estudo. Escolhemos, assim, os brincantes do teatro, justamente porque, no teatro, concentra-se um número maior das diferentes esferas artísticas mencionadas: figurinos, músicas, encenação etc. 
O Seu Estrelo define essa expressão estética como teatro de terreiro, termo que pretendemos elucidar nos próximos dois capítulos, visto que é um conceito bastante peculiar ao grupo e não encontramos pesquisas relacionadas ao assunto. Por este e por vários outros aspectos já apontados, reforçamos que nossa pesquisa se situa em uma zona pouco desbravada. Logo, vale destacar a sua importância em investigar temas ainda periféricos, na interface entre a psicologia da arte e a cultura/arte popular.

Para tanto, nosso foco é o/a brincante, o/a artista popular. Por essa via, indagamos: o que é ser brincante no contexto da cultura popular? Quais são as produções de sentidos que constituem os/as brincantes? Num desdobramento, também questionamos: quais são as transformações de sentidos do brincar no decorrer das trajetórias de vida dos/as brincantes, da infância à fase adulta? Qual é a relação entre tradição e inovação em suas brincadeiras de teatro de terreiro? Quais dimensões políticas (de resistência) constituem suas atuações como brincantes?

\subsubsection{Objetivos}

A partir das discussões teóricas e do recorte de campo apresentados, o nosso objetivo geral é analisar a produção de sentidos na/da constituição do/a brincante no contexto da cultura popular. Para tanto, delimitamos os seguintes objetivos específicos:

a) analisar a transformação de sentidos do brincar, articulada às histórias de vida dos/as brincantes;

b) investigar a relação entre tradição e inovação na constituição dos brinquedos e das brincadeiras; e

c) identificar a dimensão política (de resistência e luta) na atuação dos/as brincantes. 


\section{METODOLOGIA}

\subsection{Comunicação e investigação narrativa}

Apesar de ter sido conceituada durante décadas como uma cultura de tradição oral (Chartier, 1995), seria incoerente afirmarmos que a cultura popular se constitui atualmente apenas por meio da oralidade (Brandão, 2009). Embora o contar/narrar histórias continue sendo um quesito relevante no desenvolvimento dos saberes e fazeres ditos populares, entendemos que a narrativa não se limita à oralidade, envolvendo outras dimensões, como os gestos, os silêncios, a própria escrita etc.

Para Benjamin [1892-1940], a narrativa floresceu durante muito tempo num meio de artesãos, sendo, ela própria, uma forma artesanal de comunicação, tão antiga quanto a humanidade. Nesse artesanato das palavras, os fatos não são transmitidos na neutralidade - como pretensamente sugerem relatórios e outras formas de comunicação —, pois a narrativa "[...] mergulha a coisa na vida do narrador para em seguida retirá-la dele. Assim se imprime na narrativa a marca do narrador, como a mão do oleiro na argila do vaso" (Benjamin, 1994, p. 205). Dessa maneira, o narrar é também parte do narrador, a sua extensão no mundo.

Por essa via, a narrativa é muito próxima da arte; inúmeras vezes, é a própria arte (Benjamin, 1994). Trata-se de uma arte-artesanal (termo nosso) moldada em um tempo diferente do falar, muitas vezes, acelerado do cotidiano, da vida ordinária. Narrar, ao contrário, implica certa falta de pressa, um desaceleramento extraordinário - um pausar despreocupado para compartilhar uma história, escutar e ser profundamente escutado.

Outra questão interessante da narrativa diz respeito a pensá-la como um indicador qualitativo que auxilia na abordagem dos processos de constituição de 
subjetividades (Fontana, 2000). Assim, além de entendê-la como uma forma artísticaartesanal de comunicação, aqui nos interessa principalmente refletir sobre o seu papel na construção de dados para análises sobre a constituição de subjetividades; especificamente, na constituição de sujeitos que optaram por seguir um caminho artístico, de brincante.

Desse modo, ao enfatizarmos a narrativa como abordagem investigativa, estamos levando em consideração a existência de diálogos entre sujeitos que se metamorfoseiam entre os papéis de narrador e ouvinte. Segundo Fontana (2000), nesse processo conjunto, há um compartilhamento de memórias comuns:

narrar pressupõe uma comunidade de vida e de discurso entre o narrador e o ouvinte, fundada em uma tradição e memória comuns. Aquele que narra (com)partilha saberes e vivências nos quais seus ouvintes se re-conhecem e, pelo re-conhecimento, inserem-se na história que está sendo narrada, fazendo sugestões sobre sua continuação, vivendo essa continuação. (Fontana, 2000, p. 223, grifo nosso)

Assim, observamos que narrador e ouvinte são, ambos, sujeitos ativos na constituição de uma mesma trama ou drama, sendo frágil o limite que define um e outro. A partir dessa lógica (dialógica), evidenciamos que trabalhar a narrativa como abordagem investigativa implica refletir sobre a dinâmica constituição dos papéis sociais — seja de narrador e ouvinte, seja de pesquisador e sujeito/objeto pesquisado. Aprofundaremos esse aspecto dialógico a seguir, nas considerações acerca do método de construção de dados escolhido para este estudo, denominado entrevista narrativa. 


\subsection{A entrevista narrativa como construção de dados: coerência entre teoria e método}

A entrevista narrativa (EN) é um método diferenciado das demais formas de entrevista, principalmente por seu caráter não diretivo, presente nos formatos perguntaresposta. Composta por informante (narrador) e pesquisador (ouvinte), a EN exige do pesquisador o desafio de despertar ou instigar narrativas em seu informante (Jovchelovitch \& Bauer, 2002).

Tais narrativas podem perpassar pelas impressões tanto do real como da fantasia do narrador e devem abarcar uma estrutura sequencial composta por começo, meio e fim. Para os pesquisadores Jovchelovitch e Bauer (2002), a EN é indicada em pesquisas que combinam histórias de vida a contextos sociais específicos.

Contudo, apesar de considerar as definições da EN exploradas pelos autores, neste trabalho, partimos da premissa de que, mesmo existindo uma delimitação entre pesquisador/entrevistador e informante/narrador, durante a entrevista, essa delimitação é tênue e possui um caráter dialógico. Isso porque, como explicitamos na apresentação deste trabalho, trata-se de uma pesquisa realizada em um contexto comum aos/às participantes e à pesquisadora. Isso implica pensarmos sobre o duplo papel assumido pela pesquisadora nas ENs: ora como pesquisadora ouvinte, ora como a própria narradora.

Assim, aproximamo-nos também das contribuições de Oliveira (2012) sobre experiências narrativas. Para a autora, "narrativizar a experiência é mais que enunciar em primeira pessoa textos sociais; envolve sempre agregar à trama dos discursos um plus de sentido subjetivo" (Oliveira, 2012, p. 370) — sentido este que integra as experiências do narrador e do (com o) ouvinte (e vice-versa). 
Para Jovchelovitch e Bauer (2002), a EN visa privilegiar a linguagem do narrador - fato que exige do pesquisador um cuidado e uma apropriação da linguagem do outro na reformulação de sua própria linguagem. Para que isso ocorra, toda EN requer, antes de sua ocorrência, um convívio aprofundado com os sujeitos do e no campo de pesquisa. Esse aspecto, neste trabalho, foi facilitado, pois, na condição de brincante, a pesquisadora já compartilhava uma linguagem comum ao meio havia anos.

Assim, percebemos que esse cuidado com a linguagem que existe na EN é uma das maiores contribuições do método para esta pesquisa. Isso porque tivemos a preocupação em realizar este trabalho com os outros, dando-lhes voz - na medida em que incorporamos essas múltiplas vozes, tanto na estrutura textual da pesquisa quanto na voz da pesquisadora-brincante durante as ENs.

Porém, não se trata apenas de uma incorporação de vozes do outro por parte da pesquisadora. Há, sim uma via de mão dupla em que, ao mesmo tempo que a pesquisadora se apropria dessa linguagem do outro, o outro inevitavelmente também se apropria da sua linguagem: “[...] há um sujeito que fala e produz texto tanto quanto o pesquisador que o estuda" (Amorim, 2004, p. 16).

Dessa forma, não nos cabe a ideia de uma pesquisa neutra, que evidencia o outro (objeto e sujeito de pesquisa) em plenitude ou em sua forma pura, idealista ou romântica. Na realidade, toda pesquisa carrega uma dimensão autoral do pesquisador, que decide por aquilo, do outro, que será evidenciado ou silenciado de acordo com seus objetivos. E esses objetivos abarcam necessariamente uma dimensão política (ou projeto político) de atuação no mundo.

Há, contudo, uma possibilidade, complexa, de buscar um diálogo mais amplo com esse outro e de admitir que, apesar de ser registrada pelo nome do/a pesquisador/a, toda pesquisa é repleta de inúmeras vozes, também autorais (que a constitui). Conforme 
apontamos no capítulo 2, para Vigotski (2009), toda criação — seja uma tese, uma obra de arte etc. — parte de um princípio histórico e social. Nesse sentido, esta pesquisa busca evidenciar a multiplicidade de vozes (de sujeitos) que a integra.

Ainda sobre esse assunto, Amorim (2004) desenvolve reflexões importantes sobre o pesquisador e seu outro à luz dos conceitos bakhtinianos de polifonia e dialogismo. Segundo a autora, "em Bakhtin a polifonia é a marca fundamental de alteridade" (Amorim, 2004, p. 50) e se efetiva por meio do diálogo com o outro, dos encontros.

A autora esclarece, ainda, que historicamente existe, nas ciências sociais, um grande problema em relação à interpretação do conceito de polifonia (ou de dialogismo), em Bakhtin. Segundo Amorim (2004), na realidade nunca há um dialogismo absoluto nem um monologismo absoluto em uma pesquisa - do campo ao seu acabamento textual -, mas sim sempre algo tensionado entre essas duas dimensões.

Nesta pesquisa, é interessante enfatizar essa tensão presente nos diálogos/narrativas emergidos dos encontros dinâmicos da pesquisadora com os/as brincantes; do/s eu/s com o/s outro/s e vice-versa. Esse aspecto dialógico, que permeou a própria prática de campo, aproxima-se profundamente do princípio dialético da abordagem histórico-cultural, discutido no primeiro capítulo.

Outro ponto que tange à EN e reforça a sua coerência com a teoria discutida diz respeito aos aspectos micro e macro que a constitui como método de pesquisa. Segundo Jovchelovitch e Bauer (2002), a EN privilegia a construção de enredos que revelam aspectos micro e o macro dos acontecimentos narrados na história:

é através do enredo que unidades individuais (ou pequenas histórias dentro de uma história maior) adquirem sentido na narrativa. Por isso, a narrativa não é 
apenas uma listagem de acontecimentos, mas uma tentativa de ligá-los, tanto no tempo, como no sentido. (Jovchelovitch \& Bauer, 2002, p. 92, grifos nossos)

Portanto, o enredo, elucidado por meio das narrativas, seria uma pequena célula de estudo (micro) de um contexto maior (macro) que engloba as atividades artísticas populares; e que nos auxilia a pensar sobre a produção de sentidos na/da constituição dos/as brincantes. Isso dialoga também com a defesa de Vigotski (conforme citado por Cole \& Scribner, 2007) de que a essência geral (maior) dos fenômenos psíquicos pode ser investigada por meio de acontecimentos menores, da microanatomia. Assim, a EN pode ser aqui considerada também um estudo micro (da produção de sentidos subjetivos) de um aspecto macro do psiquismo humano (imaginação, criação etc.).

\subsection{Especificidades de uma pesquisa de fronteira (psicologia da/e arte): aspectos éticos sobre a identificação dos/as participantes}

Por realizarmos uma pesquisa que se estabelece no diálogo entre a psicologia da arte e a própria arte (como campo específico do saber humano), algumas questões éticas sobre a identificação dos participantes tiveram que ser reformuladas. Isso porque na maior parte das pesquisas em psicologia do desenvolvimento, a identificação dos sujeitos participantes é omitida com a finalidade de resguardar sua integridade física e moral.

Contudo, neste trabalho optamos por identificar os/as participantes, pois entendemos que as questões analisadas não colocam em risco a integridade física, mental e moral dos/as mesmos/as. Além disso, conforme elucidamos no capítulo 2, a autoria na dimensão da arte e cultura popular é um aspecto relevante. Nesse sentido, omitir a identificação dos/as participantes poderia acarretar a omissão da própria 
autoria, fato que seria uma incongruência entre teoria e prática sustentadas neste trabalho.

Outro ponto é que, à medida que investigamos a produção de sentindo da/na constituição dos/as brincantes (que envolvem as suas manifestações concretas, como já elucidamos) e os descrevemos/interpretamos, explicitamos características que são próprias do grupo, o que, consequentemente, o tornaria reconhecível. Desse modo, antes de iniciarmos o trabalho de campo, solicitamos as autorizações de todos/as os participantes, explicitando que eles/as seriam identificados. Após tais autorizações, o projeto da pesquisa foi encaminhado ao comitê de ética do Instituto de Humanas (Universidade de Brasília), que o aprovou.

\subsubsection{Características do campo e do grupo participante}

Todos/as os/as participantes desta pesquisa são brincantes do grupo Seu Estrelo e o Fuá do Terreiro e possuem idade superior a dezoito anos. Na primeira etapa do estudo, de contextualização do campo, trabalhamos com sete integrantes: Rodrigo (Tico), Luciana (Lu), Luís Felipe (Lipe), Sarah, Camila, Danielle Freitas e Daniele Neri. Já na segunda etapa, de entrevistas narrativas, participaram: Tico, Lu e Lipe.

A primeira etapa do trabalho de campo ocorreu ao longo do primeiro semestre de 2013, de março a junho, em que acompanhamos semanalmente (às sextas, das $15 \mathrm{~h}$ às 18h) quinze ensaios do grupo de teatro, além de duas apresentações; uma na sede do próprio grupo, localizada em Brasília (DF), e outra na cidade de Taguatinga (DF), no Beco Cultural, a convite do coletivo Invenção Brasileira.

Devido à aproximação já estabelecida com o grupo antes do início da pesquisa, encontramos a necessidade de uma reaproximação do campo de forma distinta da habitual: da posição de brincante para a de pesquisadora. Isso, contudo, não significou o 
encobrimento das percepções e memórias imanentes dos aprendizados como brincante, mas um reposicionamento fundamental, que diferenciou a prática da brincante da prática da pesquisadora.

Nesse reposicionar, houve o esclarecimento dos objetivos do trabalho ao grupo e a solicitação da autorização por parte dos/as participantes para a realização da pesquisa, como esclarecemos. Em seguida, iniciamos o acompanhamento semanal dos ensaios, utilizando diário de campo e videogravação como instrumentos. Visamos, assim, a uma contextualização mais aprofundada do campo e à preparação das ENs.

Nesse período, o grupo ensaiava em um espaço alugado conhecido como casinha. Já na segunda etapa do estudo, realizada no segundo semestre de 2014, a sede do grupo havia migrado para duas casas ao lado da casinha. Esse novo espaço foi batizado pelo grupo como Centro Tradicional de Invenção Popular, onde Seu Estrelo mantém suas atividades até o presente momento.

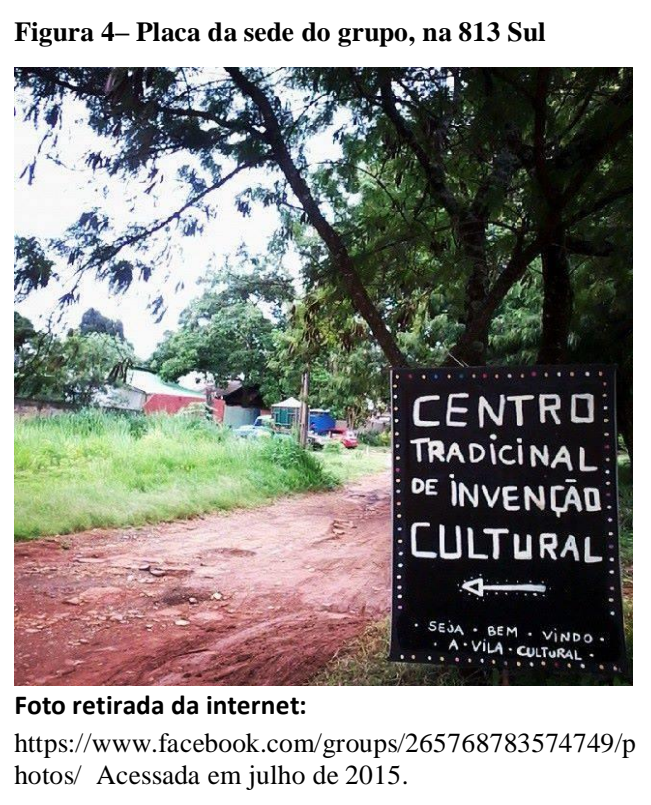

Esse novo espaço vem sendo sustentado principalmente por meio de oficinas, ministradas pelos/as próprios/as brincantes. Este ano, por exemplo, já ocorreram diversas delas, como a de Percussão Brasileira, ministrada pelo fundador Tico, e a de Danças Populares, ministrada por Lipe. Além disso, o Centro abriga ensaios regulares de outros grupos, como é o caso da Orquestra Alada Trovão da

Mata, que ocupa o lugar nas tardes de sábado e também contribui para a sua manutenção. 
É interessante ressaltar que a quadra onde o Centro se localiza é ocupada por casas residenciais e por vários espaços culturais, ambientais e religiosos, como é o caso do Circo Inventado, da Rocinha, da Casa da Árvore e do Centro Espírita Pai Joaquim de Aruanda. Devido a essa característica, a quadra (813 sul) foi recentemente nomeada como Vila Cultural.

Na Vila há, portanto, um constante trânsito Figura 5 - Placa da Vila Cultural de mobilizadores/as culturais, incluindo nossos/as brincantes e diversos/as outros/as artistas populares, muitos/as destes/as, inclusive, são estrangeiros/as (latinos/as). Esse aspecto proporciona um rico intercâmbio cultural e afetivo, constituindo um espaço dinâmico e singular na cidade.

Assim, o grupo Seu Estrelo faz parte desse

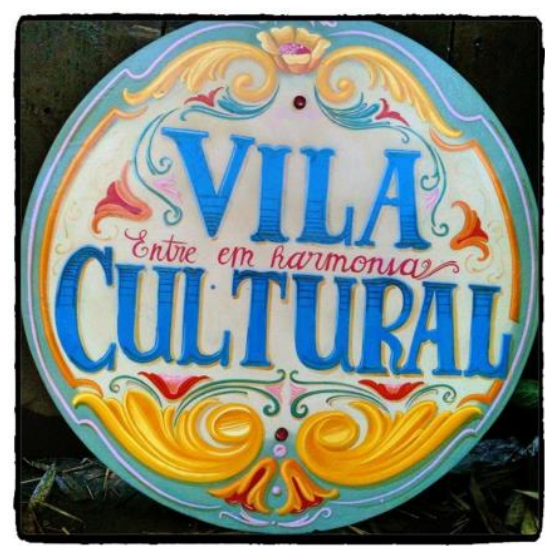
Foto retirada da internet: https://www.facebook.com/groups/2657687835 74749/photos/ Acessada em julho de 2015.

lugar culturalmente efervescido. Muitos de seus participantes atuais frequentavam outros espaços da Vila antes de integrarem o grupo, como Lu, Sarah, Camila e Danile Neri. Outros estão no grupo desde o início: Tico, Lipe e Danille Freitas, além de Camila, que, na época da pesquisa, já estava no Seu Estrelo havia cerca de um ano.

Por se tratar de um grupo que desenvolve múltiplas atividades artísticas e integra vários participantes (atualmente, quatorze pessoas), o Seu Estrelo possui uma rotatividade parcial de integrantes. No ano em que iniciamos a pesquisa, por exemplo, mais da metade do grupo antigo do teatro havia saído. Nesse período, convergiu de entrarem três integrantes que continuam no grupo até a presente data: Sarah, Lu e Dani Neri. Porém, no decorrer da pesquisa (2013-2014), Sarah deixou o grupo de teatro para compor a parte musical da brincadeira. 
Nessa complexa dinâmica, o Seu Estrelo vem, ao longo de mais de uma década, resistindo e lutando para manter sua brincadeira viva. Assim, o grupo tem também ganhado cada vez mais visibilidade na cena cultural de Brasília e de outras cidades por onde tem brincado.

Figura 6 - Seu Estrelo em matéria de jornal
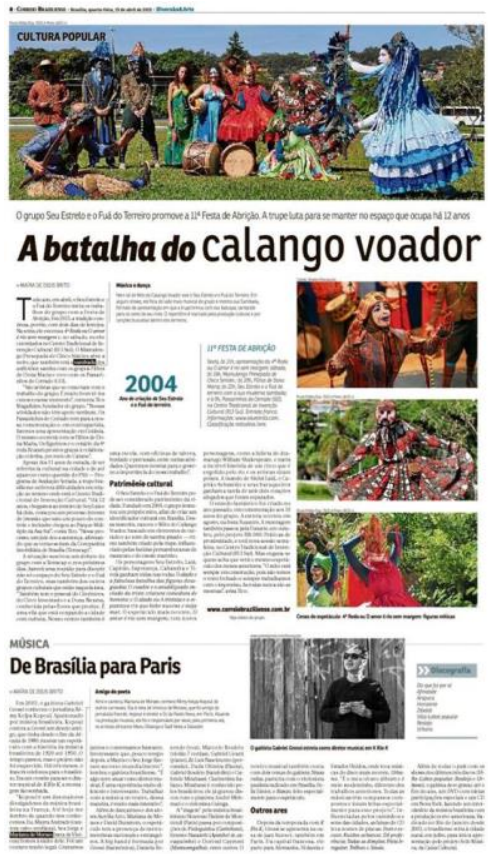

Fotos retiradas da internet:

https://seuestrelo.wordpress.com/ Acessada em julho de 2015.

\section{Figura 7 - Seu Estrelo em programa de rádio}

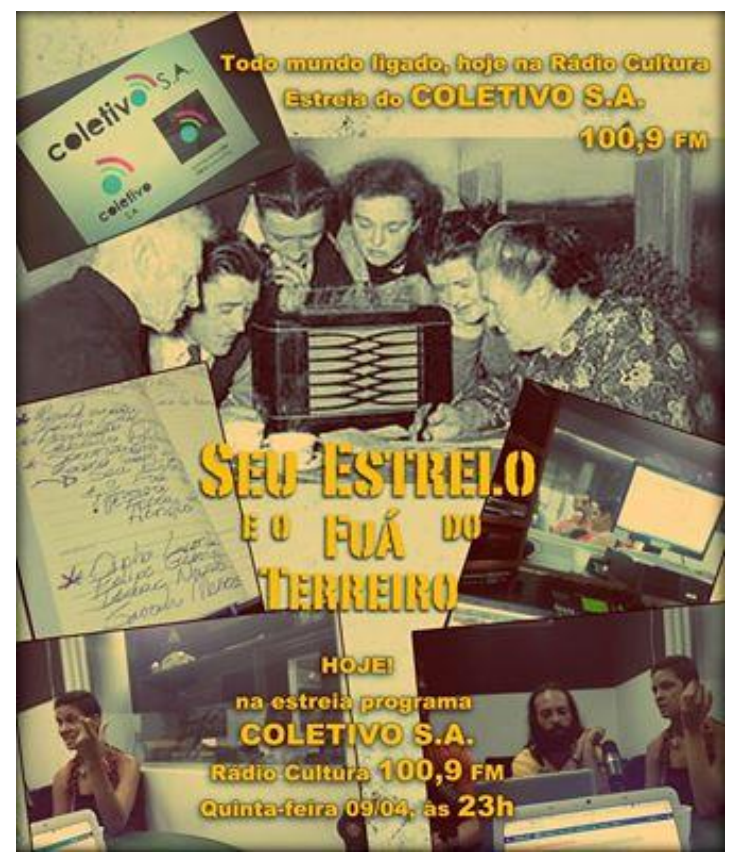

\subsubsection{Breve histórico do grupo participante}

O Seu Estrelo e o Fuá do Terreiro iniciou sua trajetória, em 2004, na cidade de Brasília. Segundo seu fundador, Tico Magalhães, o grupo surgiu com a ideia de criar uma brincadeira que abarcasse os elementos da própria cidade: seu bioma, seus moradores/as, sua história etc. 
Figura 8 - Seu Estrelo, terceira roda (Funarte, 2013)

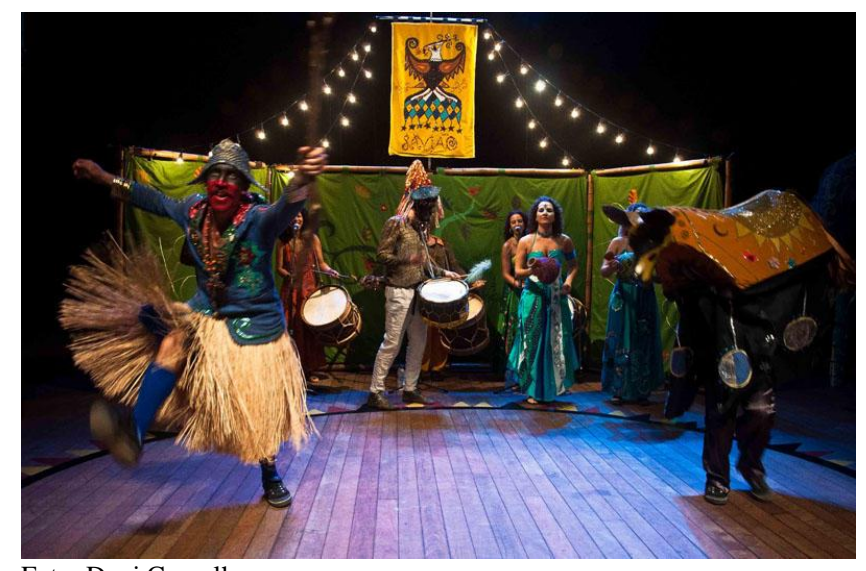

Foto: Davi Carvalho

Desde então, o grupo vem desenvolvendo sua brincadeira com elementos bastante peculiares, que trazem a influência de diversas expressões da cultura popular nordestina, como o cavalo marinho e os maracatus de baque solto e virado.
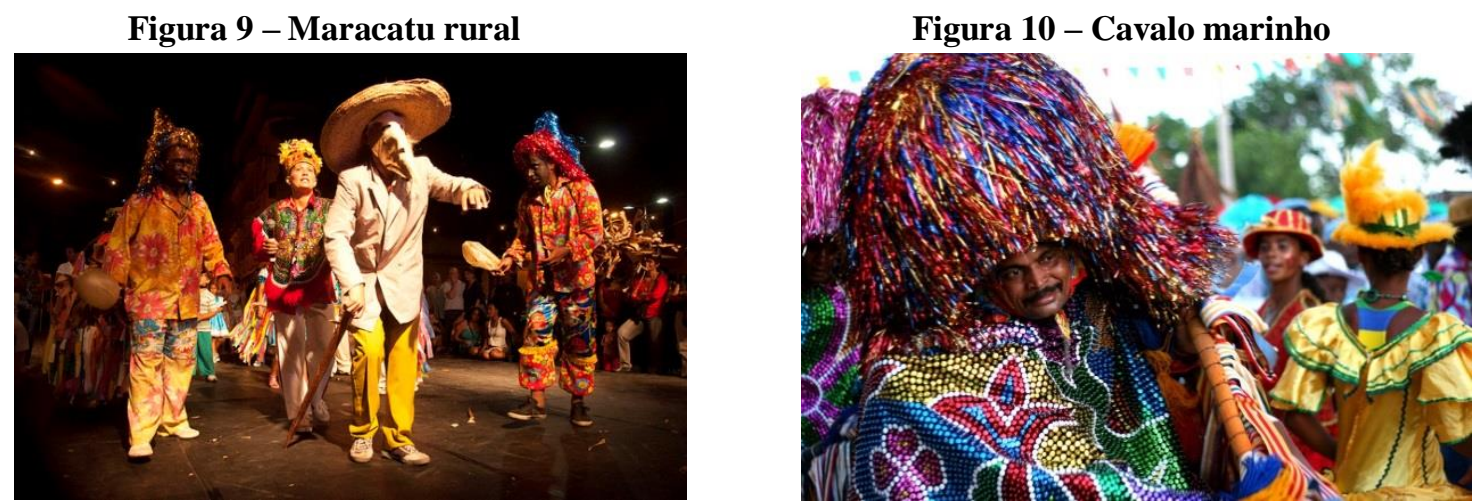

Fotos retiradas da internet: 8. wikidanca.net e 9. Jornadasvisuaisdebetania.wordpress.com / Acessadas em julho de 2015.

Assim, "unindo o terreiro e o picadeiro numa singular e moderna brincadeira" $^{22}$, o grupo conta uma história mítica sobre a origem do mundo e da humanidade, centrada na história de Brasília e do Cerrado: o Mito do Calango Voador ${ }^{23}$. Com diversas figuras ${ }^{24}$ fantásticas que moram na Celestina (terra sagrada das figuras), a brincadeira do grupo é feita em rodas. Segundo Tico, tal brincadeira é uma

\footnotetext{
${ }^{22}$ Site oficial do Seu Estrelo. Disponível em: < http://www.seuestrelo.com/\#!grupo/cjg9>. Acessado em: julho de 2015.

${ }^{23}$ Ver anexos, página 176.
} 
espécie de teatro de terreiro, que conecta a terra comum, dos humanos, à Celestina (das figuras encantadas).

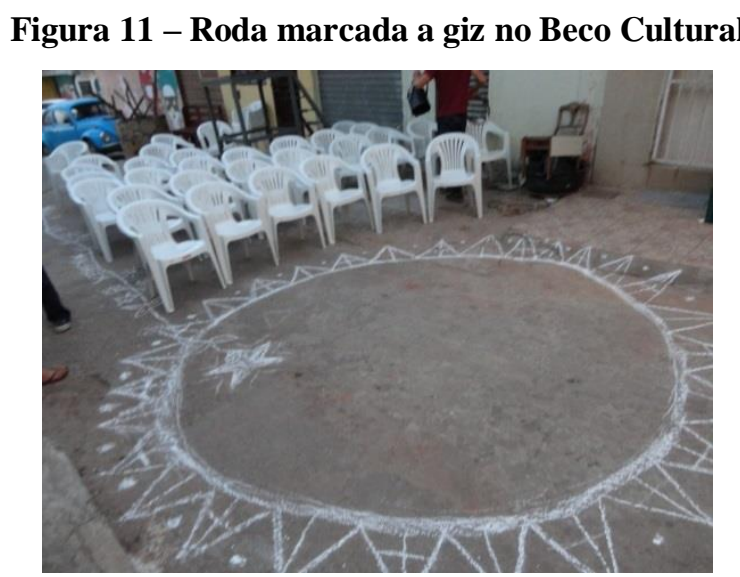

Fotos da pesquisadora (acervo particular, 2013)

Assim, o Seu Estrelo constrói suas rodas a partir de uma complexa mistura, que envolve a botação de figuras (cênica), o toque/chamada de cada figura (música), o cenário e os figurinos (plástica/visual). No que diz respeito à construção das figuras, que é o que mais nos interessa nesta pesquisa, o grupo dedica-se semanalmente aos encontros (ensaios) que visam às suas botações constantes.

Figura 12- Dani N. botando a Véia Tiroiá e Lipe como Capitão

Figura 13- Tico botando a Véia Tiroiá
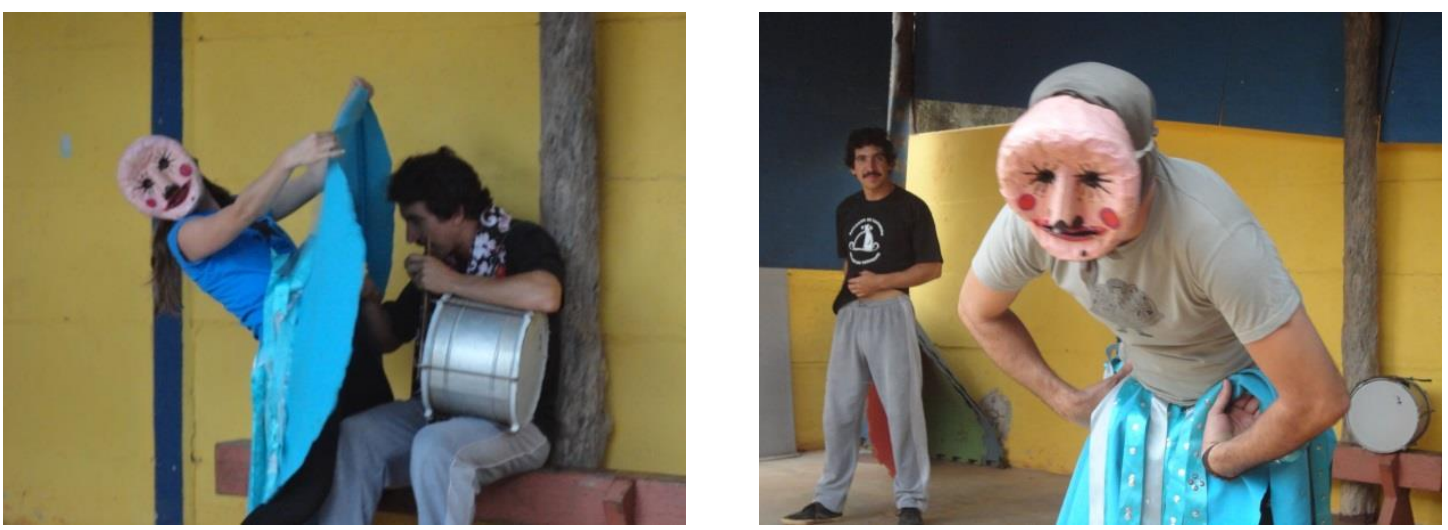

Fotos da pesquisadora (acervo particular, ensaios de 2013)

\footnotetext{
${ }^{24}$ Diferente de personagens que são encenados durante uma peça de teatro, a brincadeira cênica do grupo implica botar figuras, ou a botação de figuras.
} 
A cada nova roda - que poderíamos fazer uma analogia ao termo espetáculo ${ }^{25}$ —, determinadas figuras são botadas ou são chamadas para entrar. Atualmente, o grupo já está em sua quarta roda, denominada de $O$ amor é rio sem margem. Contudo, aqui iremos nos referenciar principalmente às figuras da terceira roda do grupo - $O$ alado, $a$ tristeza e o espantoso rio que bebe nuvens e mija mar —, já que durante a primeira etapa da nossa pesquisa de campo o Seu Estrelo trabalhava a recriação dessa roda.

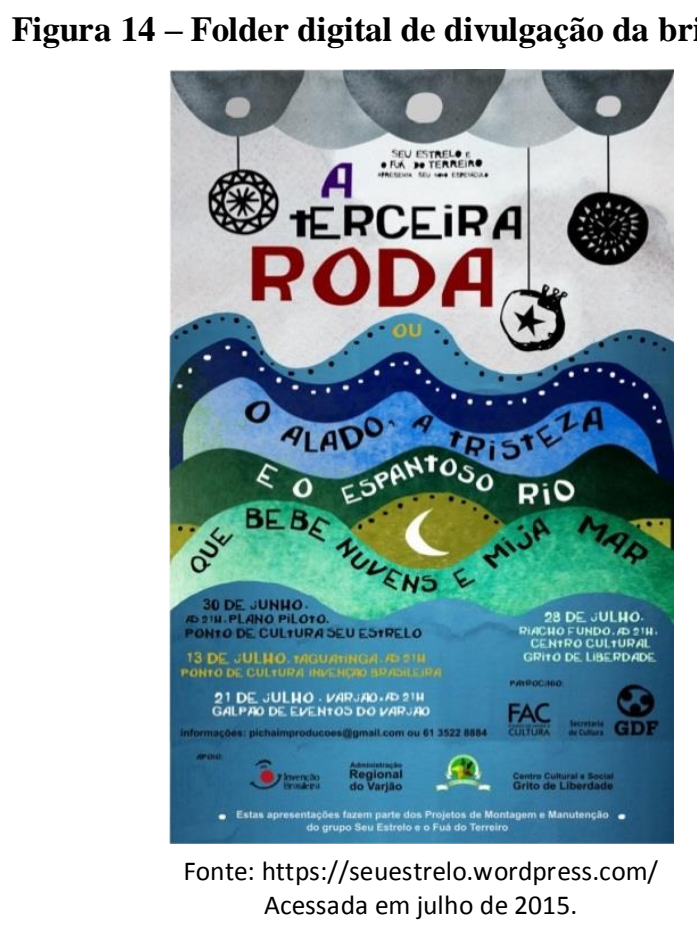

No que diz respeito a esse universo da roda e da botação de figuras, é importante esclarecer que cada figura possui características próprias: história, figurino, dança e música. A música, conforme apontamos, faz as chamadas das figuras; a música em si é uma chamada. Essas chamadas possuem um toque peculiar, uma batida própria nomeada de samba pisado.

\footnotetext{
${ }^{25}$ Nesse caso, o termo espetáculo não tem relação com o conceito de espetacularização, já discutido.
} 
Figura 25 - Capa do CD do Seu Estrelo (2009)

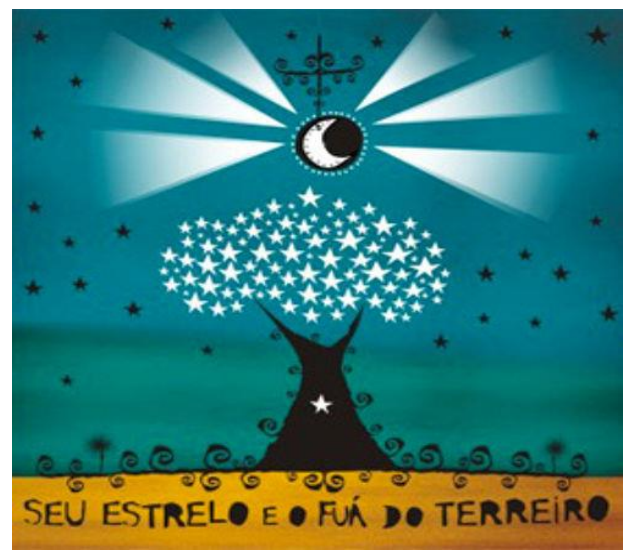

"A batida do samba pisado é uma pancada no pé do ouvido feita para o ouvido do pé." (TT Catalão - poeta de Brasilia)

Fonte: https://seuestrelo.wordpress.com/

Acessada em julho de 2015.

Entre essas inúmeras figuras fantásticas, inventadas pelo grupo, quatro requerem uma explicação mais específica; visando elucidar, de forma bastante sucinta, a sua brincadeira; pois, acreditamos que ela só pode ser compreendida em profundidade a partir da própria experiência estética (direta) com a roda. As figuras são: Seu Estrelo, Laiá, Capitão Sebastião e Calango Voador.

\subsubsection{As figuras encantadas: uma licença poética para a imaginação}

O Seu Estrelo, figura que dá nome ao grupo, é um ser caçador e protetor das Matas (que também é uma figura). Filho de Laiá, na roda, ele é a figura que promete trazer o Calango Voador para o público-brincante ver. Seu símbolo é o arco e flecha.

Figura 16 - Seu Estrelo, terceira roda (Funarte, 2013)

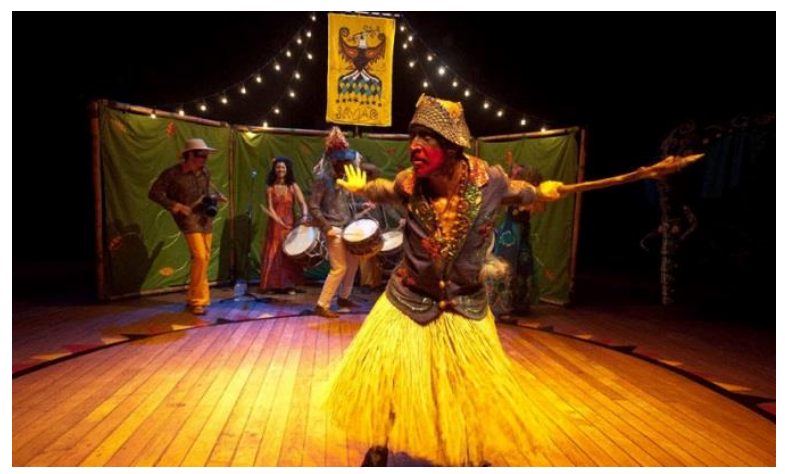

Trecho da letra de sua chamada:

Seu Estrelo tá chegando

Seu terreiro tá em festa

Vem caboclo, vem das Matas

Caçador de uma flecha!

Foto: Pedro Rocha 
Laiá é, por sua, vez mãe de Seu Estrelo e filha de um cantar da Mata (a qual Seu Estrelo se tornou protetor). Seu símbolo são as águas do Rio. Laiá é a figura que lava a roda para que ela possa começar limpa e protegida das 'coisas ruins': uma sereia de água doce que encanta qualquer um.

Figura 17 - Laiá, terceira roda (Funarte, 2013)

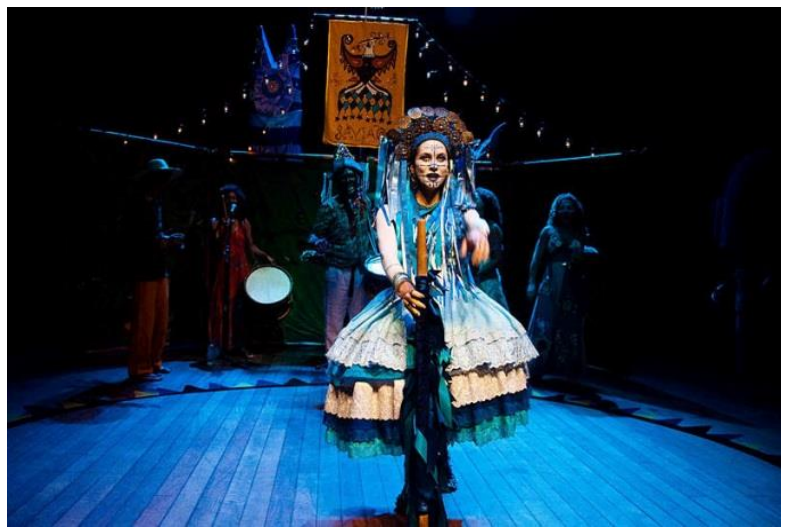

Trecho da letra de sua chamada:

Sinhá Laiá que traz o Rio

Sinhá Laiá traz o Rio

Sereia Laiá que traz o Rio

Sinhá Laiá traz o Rio

Olha o Rio, sinhá!

Foto: Pedro Rocha

O Capitão Sebastião é uma figura que faz uma espécie de ponte entre as demais figuras da Celestina e o público. Ele fica presente ao longo de toda a roda e entra tocando o baque do grupo (música instrumental). Bastião, como é chamado vez ou outra, conquista a amizade do público pela sua simpatia e destreza.

Figura 18 - Capitão Sebastião, terceira roda (Funarte, 2013)

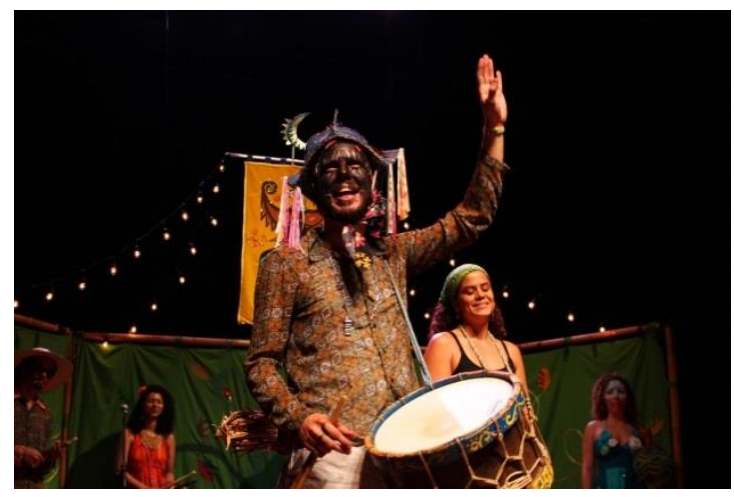

Foto: Davi Carvalho 
O Calango Voador é o filho do Sol com a Terra, uma figura mítica da Celestina vista raramente no 'mundo de cá'. Além de corpo de calango com asas nas costas, carrega um pedaço do Sol na boca. O bichinho-gigante é tão reluzente e bonito que ilumina até as noites mais escuras. Não há quem não tenha vontade de ver esse calango voando! Assim, a brincadeira da terceira roda gira em torno da sua, um tanto 'duvidosa', existência. Logo no início da roda, o Seu Estrelo faz uma promessa ao Capitão Sebastião que trará essa criatura alada para que todos comprovem sua veracidade.

Figura 19 - Calango Voador, terceira roda (Funarte, 2013)

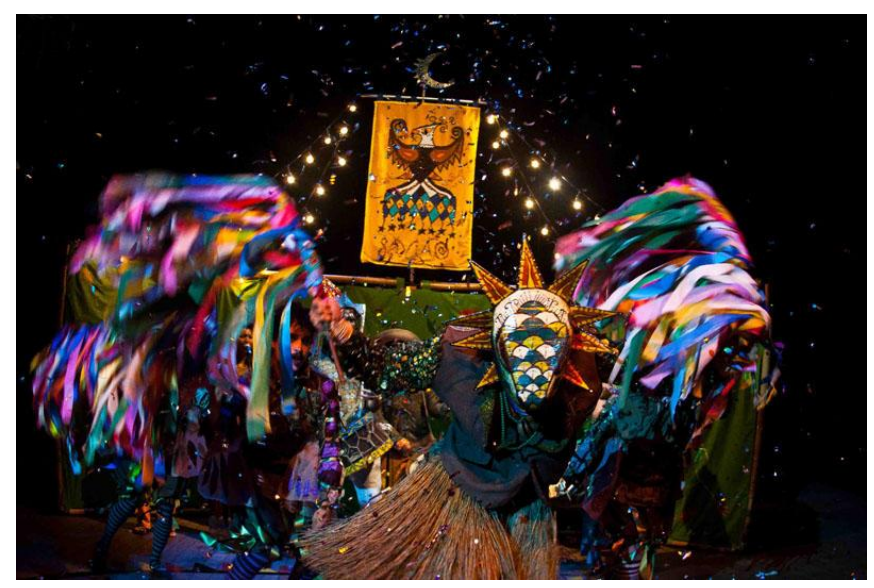

Trecho da letra de sua chamada:

Um Calango coroado, ai, ai Nasce em sua moradia, ai, ai Vem louvando, vem louvado, ai, ai Vem sambando essa folia, ai, ai

Foto: Pedro Rocha

Nos onze anos de existência do grupo, as figuras, de modo geral, já foram botadas por diferentes integrantes. Entretanto, apenas o Seu Estrelo e o Capitão Sebastião estão, desde a sua origem, sendo botados pelos mesmos sujeitos: Lipe e Tico, respectivamente. Essa característica será aprofundada no próximo capítulo, de análise e discussão dos dados. A seguir, elucidamos a segunda etapa de construção dos nossos dados, as ENs. Além disso, traçamos um perfil dos/as integrantes que participaram dessa etapa. 


\subsection{Narrativas: construção dos dados e perfil dos/as participantes}

Desenvolver uma pesquisa com base em EN exige uma aproximação e interação prévia com o campo (Jovchelovitch \& Bauer, 2002), conforme elucidamos anteriormente. Para tanto, como explicamos, realizamos uma etapa de reaproximação do campo, anterior às entrevistas. Esse período foi essencial, pois nos deu subsídios para formular e reformular os eixos temáticos que focalizamos durante as ENs. Fizemos tais reformulações com base em análises das enunciações dos/as participantes ao longo dos ensaios. Por exemplo, a questão da resistência/luta — dimensão política —, observada na primeira etapa, foi resgatada pela pesquisadora durante as ENs. No total, realizamos três ENs individuais, utilizando videogravações, com o intuito de compor dados que abarcassem a dimensão verbal e gestual/corporal das narrativas.

Os/as narradores/as foram selecionados/as de acordo com o critério de heterogeneidade em relação ao tempo de participação no grupo — dois brincantes que pertencem ao grupo desde a sua fundação, Tico e Lipe, e outra que havia entrado no início da nossa pesquisa de campo, Lu. Achamos que essa diversidade enriquece os dados, abarcando olhares mais plurais sobre a atividade do grupo e, também, sobre o tema pesquisado.

Além disso, utilizamos o critério de disponibilidade dos participantes para o agendamento das entrevistas, considerando as suas permanências no grupo de teatro durante a primeira e segunda etapa da pesquisa. Das sete pessoas que estavam na equipe durante a primeira etapa da pesquisa, duas saíram - Sarah, que passou a integrar a parte musical do Seu Estrelo, e Camila, que deixou o grupo para trabalhar no projeto cultural Brasileirando ${ }^{26}$. Assim, das cinco que permaneceram na equipe de teatro, três estavam mais disponíveis durante o período de três meses, no segundo semestre de

\footnotetext{
${ }^{26}$ Ver http://www.brasileirandotv.com.br/
} 
2014, destinado às ENs - Tico, Lu e Lipe. Como um dos eixos de análise, discutidos adiante, diz respeito à trajetória de vida dos/as narradores/as, optamos traçar um breve perfil de cada entrevistado/o:
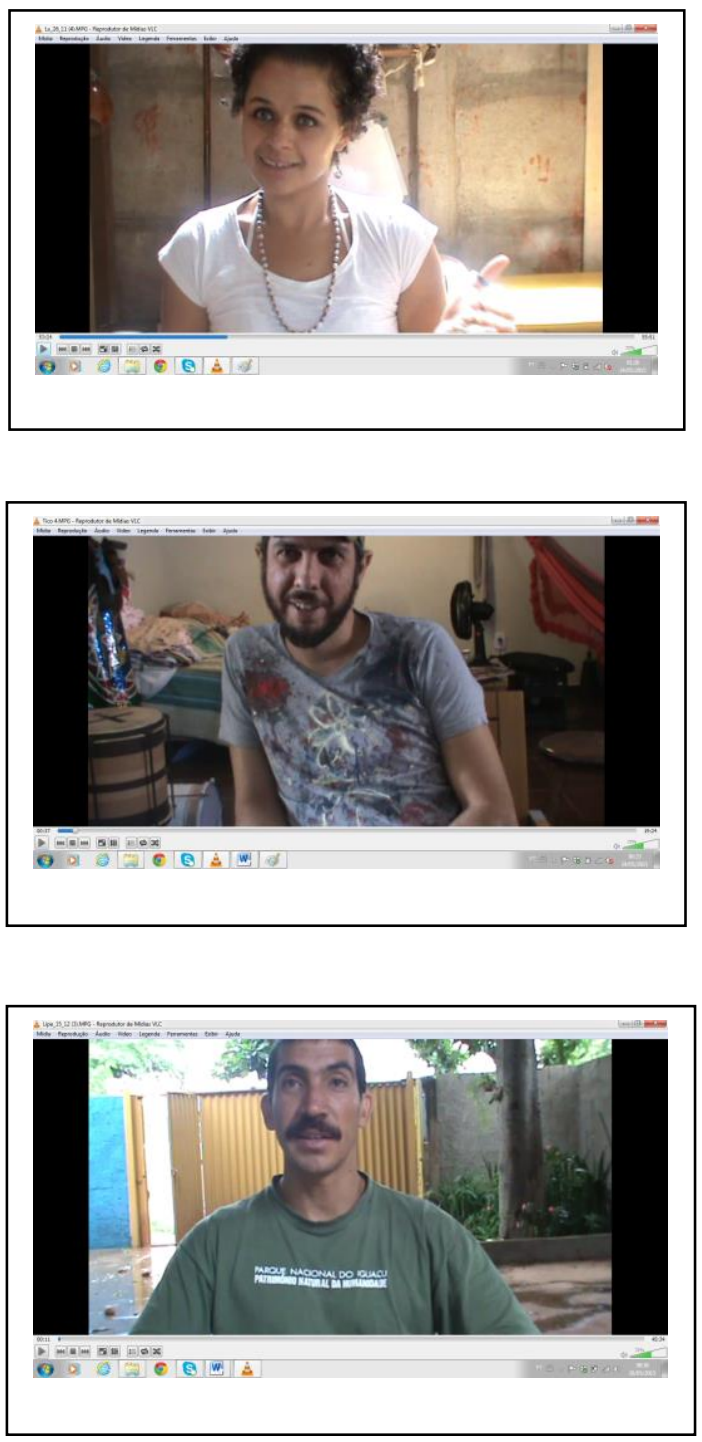

\section{Luciana Meireles (Lu)}

Naturalidade: Ceilândia - Distrito Federal Idade: 27 anos

Tempo no grupo: dois anos

Figuras que bota na terceira roda: Mané Pé Frio e Mané Pra Quê Que É Isso

Data da entrevista: 26 de novembro de 2014

Local da entrevista: Circo Inventado

\section{Tico Magalhães (Tico)}

Naturalidade: Recife - Pernambuco

Idade: 39 anos

Tempo no grupo: 11 anos (fundador do Seu Estrelo) Figura que bota na terceira roda: Capitão Sebastião Data da entrevista: 3 de dezembro de 2014 Local da entrevista: sede do grupo

\section{Luís Felipe Gebrim (Lipe)}

Naturalidade: Brasília - Distrito Federal Idade: 30 anos

Tempo no grupo: 11 anos

Figuras que bota na terceira roda: Luz Belo, Seu Estrelo e Mané Mula Manca

Data da entrevista: 15 de dezembro de 2014

Local da entrevista: sede do Grupo

Após as ENs, fizemos anotações pontuais no diário de campo, como impressões sobre os momentos mais marcantes, questões para enfatizar nas discussões do campo etc. Seguindo essa etapa, trabalhamos na transcrição das entrevistas, que optamos por ser literal, com pequenos ajustes para as normas de escrita. Nelas, buscamos também evidenciar as expressões corporais dos/as narradores/as. Encerrada a 
construção dos dados da pesquisa, partimos para sua análise, articulando os dados de ambas as etapas de campo.

\subsection{Procedimentos para análise de dados}

Os dados/narrativas transcritos foram interpretados com foco na análise do discurso. Como categoria de análise de diferentes enfoques de estudos, a análise do discurso rejeita a noção "[...] de que a linguagem é simplesmente um meio neutro de refletir, ou descrever o mundo, e [assume] uma convicção da importância central do discurso na construção da vida social”' (Gill, 2002, p. 244).

Portanto, a análise do discurso envolve o princípio norteador de que o reconhecimento da nossa maneira de compreender o mundo é condicionado pela história e cultura específica em que estamos inseridos (Gill, 2002), fato que dialoga com as discussões teóricas já apresentadas (fundamentadas tanto em Bakhtin quanto em Vigotski).

Assim, enfatizamos que todo discurso (ou narrativa) é um objeto de análise socioideológica (Bakhtin, 2006). Por essa via, é interessante citar também as contribuições de Hildebrand-Nilshon (2001), que analisa a concepção de subjetivação em psicologia não apenas pelos discursos proferidos, mas pelos discursos que são silenciados no atual contexto capitalista, de inspirações neoliberais.

Segundo o pesquisador, as próprias concepções científicas validadas em nosso tempo (socio-histórico) são, na realidade, fruto dessas incalculáveis silenciações, em que inúmeros sujeitos (e culturas) são incompreendidos e inferiorizados (vistos como não civilizados, de segundo mundo, populares etc.). Esses sujeitos, jamais possuirão voz dentro da suposta eficácia econômica do capital: "nas sociedades neoliberais o direito a falar é possuído pelas pessoas que conhecem os status de poder do meio e que 
têm posições que lhe permitem ter uma voz de primeiro mundo" (Hildebrand-Nilshon, 2001, p. 9, tradução nossa).

Em alguns desdobramentos interpretativos, notamos que as narrativas dos brincantes populares ocupam historicamente essas longas silenciações. Nesse sentido, evidenciar suas narrativas, com base na tensão dialética já explicada, é também um trabalho político de desconstrução dessa conjuntura hegemônica que beneficia e dá voz, na realidade, a uma pequena parcela social.

Por essa vertente, enfatizamos que toda pesquisa (toda ciência) é também política, por mais que ingenuamente não torne clara essa dimensão em seu discurso. Assim, os dados muitas vezes servem a um projeto sociopolítico mais amplo, que valida uns e silencia outros, ao mesmo tempo.

Logo, nossas análises pretendem ressaltar a dimensão política dos discursos ou das narrativas dos/as brincantes. Em nossa concepção, politizar tais discursos implica servir à revolucionária ampliação (ao reconhecimento) de nossas próprias potencialidades, como humanos, pelo brincar. Conforme defendemos no capítulo 3, brincar é ontológico, e se estende a todas as etapas da vida. Sobretudo, brincar é uma urgência por nós mesmos, por atribuir sentidos às nossas experiências. Assim, no próximo capítulo, investigamos a produção de sentidos na constituição dos/as brincantes em três eixos de análise:

a) da criança que brinca ao ofício de brincante: transformações de sentidos do brincar;

b) a relação entre tradição e inovação na constituição dos brinquedos e das brincadeiras; e

c) trabalho e luta: políticas de resistência pelo encantar. 


\section{APRESENTAÇÃO E DISCUSSÃO DOS DADOS}

Apresentamos e discutimos os dados, a seguir, levando em consideração a investigação central sobre a produção de sentidos na/da constituição dos/as brincantes da cultura popular. Para tanto, elencamos três eixos de análise, visando contemplar os objetivos específicos, já abordados no capítulo três. Os eixos são:

Eixo a) da criança que brinca ao ofício de brincante: transformações de sentidos do brincar;

Eixo b) d relação entre tradição e inovação na constituição dos brinquedos e das brincadeiras; e

Eixo c) trabalho e luta: políticas de resistência pelo encantar.

\subsection{Eixo A) Da criança que brinca ao ofício de brincante: transformações de sentidos do brincar}

Quando iniciamos as três ENs (entrevistas narrativas), sabíamos que elas não poderiam seguir o padrão tradicional, diretivo, de pergunta-resposta, conforme esclarecemos previamente. Mas tínhamos que partir de alguma referência. Então, decidimos iniciar com perguntas mais abertas, sobre as histórias de vida dos/as brincantes, que nos auxiliassem a percorrer a produção de sentidos da/na constituição dos/as próprios/as narradores/as.

Nessa linha, as primeiras questões colocadas foram: pensando na sua trajetória de vida, da infância até hoje, quais acontecimentos você considera mais relevantes na construção do seu caminho de brincante? Quais deles te trouxeram para este caminho do/a [Tico, Lu ou Lipe] brincante de hoje? 
Feitas tais indagações, cada brincante iniciou sua narrativa por vias singulares. Lipe, por exemplo, começou argumentando sobre a importância do brincar na infância, tendo como referência o seu trabalho de oficineiro no Circo Inventado ${ }^{27}$, no qual desenvolve atividades lúdicas com crianças. Ele diz:

“[...] eu tenho esclarecido e visto, com mais detalhes, com mais clareza, a importância do brincar pra criança, pra formação... Pra formação de uma pessoa confiante”.

Lu, por sua vez, iniciou falando sobre o seu local de nascimento (Ceilândia), sua constituição familiar (mãe e dois irmãos) e de como cresceu na ponte entre a escola, as brincadeiras na rua e a sua casa:

“[...] acabou que eu cresci muito nesse universo da escola, da rua! A gente tinha essa coisa de brincar na rua, a criançada da rua e tal... E sempre brincando muito em casa, porque tinha os dois irmãos mais novos, né?! E eu era a mais velha... Então, a gente tinha o nosso fantástico mundo em casa também”.

Já Tico descreveu a sua terra natal, Pernambuco, enfatizando a lembrança de estar com seus pais durante os carnavais de Olinda:

“painho e mainha sempre gostaram muito de carnaval, né! Então, eu lembro, de pequenininho, de ir pra Olinda com eles... Eu lembro de muita gente, muita gente! Assim, eu lembro da minha mãe de mão dada, com medo de soltar a mão e se perder ali... Lembro também de ficar na casa de um amigo, ficava brincando... Aí, depois, mainha e painho me pegavam e tal... Então, tem um pouco essa memória, assim, dessa coisa de Olinda!”

Apesar de toda essa diversidade de enfoque nas narrativas, observada desde o início, um ponto que nos chamou a atenção diz respeito ao brincar na infância. Pois,

\footnotetext{
${ }^{27}$ O Circo Inventado é um espaço cultural localizado na Vila Cultural (ver capítulo IV, seção Breve histórico do grupo participante).
} 
todos/as os/as brincantes apresentaram, em dados momentos, fragmentos narrativos interessantes sobre essa temática. Isso, por sua vez, nos remeteu às contribuições de Vigotski (2007) discutidas no capítulo III, que enfatizam o brincar como necessidade da criança, a nosso ver, uma necessidade ontológica que perdura em todas as etapas da vida humana, com diferentes nuances.

Nessa perspectiva, no que tange aos/às nossos/as brincantes, nos interessa investigar as transformações significativas do brincar ao longo de suas histórias de vida, visando compreender os sentidos que constituem os/as próprios/as brincantes como adultos que brincam de formas singulares, no contexto da cultura e arte popular.

Para tanto, percorremos as narrativas sobre o brincar nas diversas etapas de suas vidas, pois o que nos interessa demonstrar, neste eixo analítico, é como o brincar assume diversos sentidos subjetivos no decorrer desse processo histórico. Decidimos, então, iniciar pela infância e as brincadeiras de faz de conta, que foi uma temática evidenciada nos dados. Em seguida, trataremos de alguns relatos sobre a juventude, em que $o$ brincar começa a se vincular aos brinquedos populares (como o maracatu e o mamulengo). No final do eixo, abordaremos a fase mais atual dos/as brincantes, em que o brincar é discutido como um ofício de vida, uma profissão.

Assim, para Lu, a infância em Ceilândia foi cheia de recursos lúdicos. A narradora diz que sua mãe, professora de artes, teve papel fundamental nesse processo:

“minha mãe sempre possibilitava recursos pra gente. A gente sempre teve muito papel, muita tesoura, lápis de cor, tinta... E tinha os bonecos que ela usava, pra poder dar aula, tinha as máscaras que ela usava e tal... Então, de alguma forma a gente conseguia ter em casa um ambiente lúdico.” 
No ambiente lúdico de sua casa, a brincante nos conta também ter desenvolvido várias peças de teatro com seus irmãos, que eram apresentadas na varanda. Peças que, segundo Lu, juntavam a meninada da rua para assistir. Ela fala:

"a gente começava a encenar cenas da novela [risos] e, aí, juntava todas as crianças da rua na nossa porta, tipo... A porta da minha casa era [...] o palco né! Aí, juntava a criançada na porta de casa e a gente ficava do lado de dentro da grade, encenando a novela!”

Para a narradora, aquela era uma forma de continuar brincando, "o dia todo", mesmo quando sua mãe não a deixava sair para a rua. Aqui, percebemos que $o$ brincar de faz de conta é parte das experiências significativas da brincante - experiências que, ao serem recordadas, divertem e provocam, em nós (pesquisadora e entrevistada), um compartilhar de risos. E os risos, por sua vez, parecem mudar radicalmente a fluência do narrar, fazendo-nos esquecer um pouco a câmera que media nossa relação no instante da entrevista ${ }^{28}$.

Nessa nova fluência narrativa, notamos que Lu desenvolve, aos poucos, relações entre o seu brincar de faz de conta, quando criança, e as suas experiências (estéticas) como adulta:

“[...] tinha uma brincadeira que eu nunca esqueço, que era brincar de aventura! [risos]. Que a gente ia pro quintal e, aí, a gente ficava imaginando, né!? A gente tinha muito essa coisa de imaginar, a gente era muito imaginativo! A gente imaginava que estava na floresta. Daí, imaginava que estava atravessando o abismo e, aí, a gente tinha que enfrentar o furacão... Enfrentar macacos selvagens e tal. A gente tinha toda essa relação do imaginário. Então, digamos que eu explorei muito isso na infância. Se tinha uma coisa que eu gostava era aquilo! Eu acredito que as coisas já

\footnotetext{
${ }^{28}$ Os risos, de alguma forma, tornam a entrevista mais aberta e profunda, na medida em que, ao rirmos juntas, nos identificamos e criamos uma nova dinâmica relacional, mais descontraída e próxima (íntima).
} 
vêm com a gente também... Sei lá, porque eu sempre gostei muito de encenar... Assim, de fingir que era, né?! Fulano, e fingir que era Ciclano, imitar as pessoas”.

Nesse trecho, percebemos também duas questões interdependentes e relevantes para nossa pesquisa: a) a relação entre imaginação e criação e b) a relação entre $o$ brincar e a arte. No que tange à primeira delas, a narradora relata a dimensão imaginativa vigorante durante o seu brincar de aventura, o que dialoga profundamente com o que discutimos nos capítulos II e III, acerca da imaginação, dos processos criativos e do brincar. Assim, é válido, retomarmos aqui as contribuições de Vigotski (2009) sobre imaginação e criação na infância. Segundo o autor bielorrusso, a imaginação promove as ações inventivas, nas quais o brincar se integra como uma das principais atividades promotoras do desenvolvimento humano.

Tal dimensão imaginativa e criativa também pode ser observada nas narrativas de Lipe sobre uma das brincadeiras de que ele mais gostava quando criança, denominada brincar de fazer caminhos:

LIPE: “[...] nessa brincadeira, eu me amarrava! Eu sempre queria encontrar ele [um amigo], e a gente ficava brincando de passar pela casa dos outros, dos vizinhos, por cima do muro, a gente subia em cima do muro e ficava andando em cima do muro. Aí, tinha casa que tinha pé de fruta e a gente pulava pra roubar as frutas, goiaba...”

ANDRESSA: "Tinha a coisa do equilíbrio, né?!"

LIPE: “É! E de olhar as coisas por cima, ver as coisas por cima! Ver todas as casas, todos os quintais. Era uma brincadeira muito divertida! Porque, ao mesmo tempo, ninguém podia ver a gente! Então era assim... Era muito legal!”

Lipe enfatiza as regras da brincadeira de ficar invisível e, além disso, se recorda de que os meninos (ele e seu amigo) tinham que pisar em espaços específicos: 
por cima do muro, em volta da casa dos vizinhos etc. Conforme discutimos no capítulo anterior, essas regras inventadas constituem os jogos infantis de faz de conta e são elementos da dimensão imaginativa das crianças - dimensão esta que, necessariamente, integra elementos da realidade:

nessa perspectiva, é importante considerar que a situação imaginária nunca é uma livre criação das crianças, independente da realidade. Ao contrário, quando observamos a brincadeira de faz de conta, percebemos nela indicadores da experiência social das crianças e do seu conhecimento de mundo. (Cruz, 2015, p. 80).

Assim, retomamos o argumento de Vigotski (2009) de que todos os elementos da fantasia/imaginação, seja no brincar, na arte, na ciência etc., partem do universo social do qual o sujeito participa. O autor argumenta, ainda, que a imaginação é viabilizada pela realidade, ao mesmo tempo que a transforma. Trata-se de uma realidade histórica e cultural internalizada pelos processos de mediação semiótica, em que a relação com o outro é fundamental (ver capítulo 1).

Já no que tange ao segundo aspecto, parece-nos fundamental discutir a relação entre o brincar e a arte; mais precisamente, o brincar de faz de conta e o teatro. Conforme apontamos no capítulo 3, em Silva, Costa e Abreu (2015), essa é uma analogia bastante oportuna, pois, ao brincar de faz de conta, a criança assume distintos papéis, fato que se aproxima do trabalho de um ator/atriz. Nessa dinâmica dramática do brincar, o corpo, segundo esses/as autores/as, constitui a própria brincadeira e se (re)configura para "representar os personagens e objetos a serem encenados" (p. 123).

Na narrativa de Lipe, percebemos como o corpo participa da brincadeira ao se "equilibrar" e ao "olhar as coisas por cima do muro". Essa dimensão corporal, essencial ao brincar da criança, parece ser um elemento fundamental na própria 
constituição dos/as brincantes — aprofundaremos esse aspecto no nosso segundo eixo de análise, que tratará sobre a figura e o corpo na relação entre a tradição e a inovação nas expressões estéticas populares. Contudo, nos cabe, aqui, ressaltar que há uma relação próxima entre $o$ brincar e $a$ arte.

Segundo Silva (2006), o brincar infantil, em especial o brincar de faz de conta, assume uma dimensão embrionariamente artística. Tal atividade “[...] abrange modos específicos de exploração da sensibilidade da criança: a experiência de outridade e a dimensão performática que a própria vivência traduz" (p. 40).

Sobre esse assunto, Magiolino (2015) também apresenta reflexões importantes. Fundamentando-se na obra de Bakhtin, a autora discute que a diferença entre a atividade do ator e a de uma criança brincando "[...] está na ausência do espectadorautor" (Magiolino, 2015, p. 136). Desse modo, Magiolino (2015) resgata um exemplo do autor russo para esclarecer que uma criança que encena um bandido vivencia o personagem (ou a vida do bandido) por dentro. Na interpretação da criança, existe uma autovivência do personagem que a faz olhar o outro, que com ela brinca, pelos "olhos do bandido" (p. 136).

$\mathrm{Na}$ arte, contudo, há um ator que encena para um outro anunciado: a plateia/o leitor (o espectador-autor). Bakhtin argumenta que é somente nessa relação que a arte acontece (Silva, 2006; Magiolino, 2015). Isso é explicado pelo pesquisador por meio do conceito de exotopia. A exotopia, por sua vez, fundamenta-se na necessidade de participação do espectador-autor na arte; somente por um outro terceiro que uma determinada obra pode, de fato, ser esteticamente acabada. O outro, "ao ocupar um lugar de exterioridade e trazer um excedente de visão estética, a ajuda [a obra] a compor sua imagem exterior, dando-lhe um acabamento (est)ético" (Magiolino, 2015, p. 137). 
Por essa via, ao analisar o herói do drama literário, Bakhtin (1997) enfatiza a necessidade de um outro-autor (leitor) que dá sentido (acabamento) à obra de arte em razão da extralocalidade que este consegue ter da própria obra que contempla, a exotopia. Assim, uma obra artística sem um leitor-autor é uma obra morta, inexistente e inacabada. O outro-autor é quem

[...] vai subtrair o herói à solidariedade em comum e à responsabilidade coletiva e vai engendrá-lo, enquanto novo homem, num novo plano da existência, onde ele [o herói] não poderia nascer por própria conta e pelas próprias forças, onde ele reveste uma carne nova que, para ele mesmo, não é substancial e não existe (Bahktin, 1997, p. 34-35, grifo nosso).

Essa nova carne só existe, na realidade, para o outro-autor, que, pelo herói, se transforma. Nesse sentido, Bakhtin (1997) também enfatiza a dimensão da criação conjunta na arte, pois o herói só existe numa "tensão criadora” (p. 34).

No universo da cultura popular, entretanto, percebemos que as manifestações artísticas/estéticas ocupam uma linha de fronteira bastante sutil entre arte e vida (ver capítulo 3). Desse modo, nos arriscamos a argumentar que a arte popular ora se aproxima do brincar da criança, que também não depende de um outro-espectador, ora se distancia, por seu caráter estético/artístico, que apresenta uma alteração da ideia de público. Sobre aquilo, Tico comenta como a brincadeira do cavalo marinho, para ele, acontece independente da existência de uma plateia (outro-espectador): "[...] depois [remetendo-se à sua juventude], quando eu conheci o cavalo-marinho, assim, essa coisa da brincadeira pela brincadeira, não tinha nada de público... O cavalo marinho do mestre Grimário começava oito da noite, dava oito da manhã e a galera tava brincando e, assim... Eles brincando! Eles brincando a noite toda. Brincadeira deles, pra eles!” 
No trecho, notamos que, mesmo sem a presença de um outro-espectador, o brincar na arte popular agrega um valor interessante: a necessidade do cocriador (de alguém que brinca junto) e da própria comunidade, que contribui para a construção do brinquedo. Afinal, os/as brincantes ficam a noite toda brincando uma "brincadeira deles, pra eles”, que reflete e refrata uma tradição, como enfatizaremos no eixo B.

Nessa dinâmica, parece-nos importante salientar que o que está em jogo é a orientação da própria atividade estética, pois, para os brincantes, a brincadeira não se organiza orientada para um outro-espectador, mas para um outro-brincante, sugerindo um tipo diferenciado de exotopia, uma outra forma de configuração estética. Conforme discutimos no capítulo 3, mesmo havendo a existência de uma suposta plateia nas expressões populares, para que a brincadeira ocorra, de fato, esta tem que fazer parte dela, tornando-se brincante. Nessa via, desconfigura-se a ideia de público como algo externo, que contempla a obra de arte, pois, na realidade, não se trata de um público externo, mas de uma espécie de público interno: o público-brincante (termo nosso).

Nessa lógica, sugerimos que o excedente de visão (o outro-espectador), necessário ao acabamento estético, é, paradoxalmente, um excedente-interno de visão. É um outro-brincante que, por dentro da brincadeira, lhe confere o seu acabamento estético. Daqui, deriva outra análise: a relação entre a chamada arte popular e o seu suposto contrário, a arte erudita. Do ponto de vista estético, percebemos que um aspecto que diferencia profundamente essas artes não é necessariamente a qualidade bastante difícil de definir, conforme discutimos em Bulhões $(1991,2005)$ - , mas a sua orientação. Assim, nos brinquedos populares, essa complexa orientação aproxima-se do brincar de faz de conta da criança, mas também se afasta radicalmente, adquirindo características bastante singulares ao contexto artístico da cultura popular, conforme sugerimos. 
Logo, se para Lu o brincar de ser outro parece ser algo que já está com ela desde menina, um "gosto pela encenação", o brincar da brincante foi uma longa construção firmada e (re)afirmada no curso de sua trajetória de vida. Segundo a narradora, ser brincante:

“...é uma condição! Eu sou! Eu sou porque eu me vejo assim... [silêncio] É uma condição, mas é uma construção também, sabe?"

Por essa via, veremos que, na constituição dos/as nossos/as brincantes, diferente dos jogos cênicos infantis, o brincar vai se construindo como uma profissão/ofício. Esse caminho profissional, por sua vez, é profundamente marcado pela participação da família, da escola e da universidade.

Lu relata que acompanhar a mãe (professora de artes) durante a sua jornada de trabalho na escola, ainda quando menina, lhe proporcionou um gosto pelo ambiente escolar, que a brincante julga ter sido decisivo em sua formação:

"eu sempre tive uma relação muito bacana com a escola, com o ambiente escolar. A escola, pra mim, era um ambiente libertador, não era um ambiente opressor, porque era familiar, né?! Foi onde eu cresci, minha mãe... O ambiente da escola era um ambiente familiar, onde eu me soltei muito [...]. A escola pra mim foi um ambiente muito decisivo".

É nesse ambiente "familiar" e "libertador" da escola que Lu encontra também alguns professores que a inspiraram profundamente. Ela relata que isso a fez querer ser professora durante a sua juventude:

"lá [na escola] eu tive muitos bons professores. Professores incríveis, que foram assim... Chaves mesmo! Tinha um professor de história que... Nossa! Ele abriu a nossa cabeça politicamente! Ele soltava mesmo o verbo, passava filmes... E aí trouxe toda a questão da ditadura pra ser trabalhada em sala de aula. E ele era um professor 
que dava liberdade [...]. Então, acabava que meus trabalhos na escola, quase todos eu fiz em formato de peça de teatro. [...] E aí, eu vim sempre com essa ferramenta, da poesia, do teatro, da fala, do discurso e tal... Sempre um viés político, social. Então, eu decidi que queria entrar na universidade, porque eu querida ser educadora! Porque eu queria ser professora... Porque eu queria ir pra escola, né?! Fazer a revolução!’”

Nesse trecho, é interessante como a narradora cita a sua formação política, em seu tempo de escola, onde ela priorizava o teatro como forma de apresentação de suas pesquisas/ideias aos outros - experiência, esta, que foi oportunizada e incentivada, especialmente, pelo seu professor de história. Percebemos, aqui, que tal dimensão política vai constituindo a brincante de hoje, argumento que será enfatizado em nosso terceiro eixo de análise.

Tico, por sua vez, relata a participação de sua família, enfatizando o trabalho comunitário de seus pais que, segundo ele, sempre demonstraram preocupação com o social, com a vida comunitária. Sua mãe, médica, por exemplo, largou a pediatria e optou por estudar hanseníase em Cuba, "uma doença muito mais ligada à pobreza", como nos disse o brincante. $\mathrm{O}$ narrador relata ter crescido envolto por movimentos de lutas sociais, fato que, para ele, o aproximou muito do "verdadeiro sentido" da (sobre o que é) cultura popular:

“acho que tem um lado de painho e mainha que é muito social, assim, eu acho que isso me aproximou muito do sentido do que é cultura popular pra mim. [...] Eu lembro de painho muito! A gente indo muito nessa comunidade, nessa favela, [indo] pra reuniões, pra se organizar, pra que simplesmente aquilo ali [a construção de um shopping] não tirasse aquela galera, né?! E, aí, eu lembro muito de tá voltando lá pra casa e ter muita gente sempre, assim, sabe?! Dessa comunidade, desse lado. [...] Isso me aproxima muito, assim, do que eu sinto, hoje, da importância da cultura popular 
por esse lado social. Eu acho que painho e mainha desde o começo me direcionaram muito pra esse olhar, sabe? Aquele olhar pro próximo, pro outro, pra comunidade, pra aquele local, sabe assim? Eu acho que eles me trouxeram muito pra esse lado, abriram os [meus] olhos muito pra esse lado... Eu acho que é o que me faz muito fazer o que eu faço hoje".

Na narrativa acima, Tico constrói o sentido de cultura popular com base em suas experiências familiares/comunitárias. Isso nos permite retomar a noção de cultura popular que foi defendida pelos Movimentos de Cultura Popular (MCPs), de 1960 e que discutimos no capítulo 3. Relembramos que, naquele contexto, a noção de cultura popular abarcava necessariamente as lutas sociopolíticas, partindo de um princípio coletivo: trabalhar com as pessoas e não para as pessoas (Brandão, 2011; Freire, 1983).

É curioso notar que todos/as os/as brincantes entrevistados/as destacam essa dimensão sociopolítica despertada desde o berço familiar. Lipe relata:

"minha mãe, ela trabalha no INCRA [Instituto Nacional de Colonização e Reforma Agrária], né?! E aí, de vez em quando, ela trazia uns amigos nessas viagens que ela faz, desses assentamentos, quando eles precisam de alguma coisa na cidade, ela dava um suporte! Aí ela trouxe, uma vez, uma família de descendente de ciganos... Então, era um pessoal que vivia a caminhar mesmo! Nos assentamentos... Eram trabalhadores rurais, mas viviam assim [a caminhar]. Tinham um resquício de nomadismo, sabe? E aí eles falaram um monte de coisa, e isso me despertou um gosto, assim, pelos ciganos! Por essa vida viajante!”

O brincante, ao mencionar o emprego de sua mãe, reporta-se aos assentamentos e às famílias a que a mãe “dava um suporte”. Entre essas famílias, ele destaca a convivência com os outros (ciganos) que conheceu por meio da própria mãe. 
Esses outros marcaram profundamente sua trajetória, despertando um gosto especial pela "vida viajante", que parece ter bastante relação com a sua vida atual de brincante.

Lipe ressalta, adiante, que foi devido a esse gosto pela viagem, pela vida cigana e pelas amizades com artistas (latinos) que ele, aos vinte e poucos anos, resolveu cursar Letras (Espanhol). Ele conta:

"e, aí, essas foram as minhas referências, que me levaram a escolher Letras/Espanhol! Só que, aí, eu passei no vestibular e, ao mesmo tempo, começou aqui as oficinas de maracatu na casinha, foi ao mesmo tempo!" O brincante relata como, a partir de seu ingresso na Universidade de Brasília (UnB), aos poucos as atividades da "casinha" — no início da formação do grupo Seu Estrelo — foram fazendo mais sentido em sua vida. Ele prossegue:

"entre a escola da cultura popular e a academia, eu fui levando as duas coisas paralelas, ao mesmo tempo, e naturalmente eu fui convivendo mais [aqui] e o Seu Estrelo foi puxando mais pra cá, né?!"”

Lu também nos conta algo similar nessa transição entre a vida acadêmica e a vida de brincante, uma tensão. Para ela, o envolvimento com o Invenção Brasileira ${ }^{30}$, localizado em Taguatinga, foi fundamental. A brincante diz que, no processo de integrar o Invenção, a universidade foi ganhando papel coadjuvante em sua vida, tornando-se um espaço cada vez mais distante de seus ideais/objetivos, onde ela se sentia menos acolhida.

Chamou-nos a atenção, no decorrer desse relato da sua experiência de transição da universidade para o ponto de cultura, a mudança na expressão corporal da brincante

\footnotetext{
${ }^{30}$ O Invenção Brasileira é um espaço comunitário e educacional voltado para a difusão da cultura popular brasileira que integra vários coletivos artísticos, entre eles, o Mamulengo Presepada, de Chico Simões. Ver https://www.facebook.com/InvencaoBrasileiras.
} 
— de um tom mais sério (sobre a universidade), para um tom mais sorridente (sobre o ponto de cultura):

“[...] aí, eu comecei a me desligar mais da universidade e me envolver mais com o ponto de cultura, porque pra mim estava fazendo muito mais sentido, me pegou muito mais do que a universidade, porque na universidade eu tava trabalhando [coloca as mãos na cabeça]... Trabalhava muito o intelecto e tal... Apesar de ter trabalhado o corporal, mas foi um universo... [silêncio]. O que eu sinto, pra mim, na universidade, é que ficava muito distante da minha realidade e, aí, era isso, tipo: eu pegava um trânsito todo dia de quase duas horas pra poder chegar na UnB. Aí, chegava lá e a realidade do que se falava não fazia parte do meu universo. Essa sensação de... Não sei se eu pertenço a isso, sabe?! [expressão de dúvida e seriedade]. E lá no ponto de cultura, não! [sorri]. Lá, eu ia de bicicleta, ficava do lado de casa, era a galera! E a gente viajava, a gente fazia várias coisas junto. Eu acabei não criando muito vínculo afetivo com a universidade e criando muito, lá, no ponto de cultura. Então, eu comecei a deixar mesmo a faculdade de lado! Fui deixando..."

Notamos, aqui, também como os vínculos afetivos são fundamentais e norteiam as escolhas subjetivas dos/as brincantes. Como discutimos no capítulo 1, as emoções estão no cerne de tudo o que significa e dá sentido à experiência subjetiva (Magiolino, 2011). Sentidos que são constituídos nas relações de trocas e de parcerias que sinalizam aos brincantes um lugar de pertencimento no mundo. Pertencimento que, como expressa Lu, tem relação com as amizades, com “a galera”, transcendendo, portanto, a ideia de espaço físico ou geográfico. Pertencer a um lugar, por essa via, é pertencer a uma comunidade, a um determinado grupo de pessoas; é se sentir próximo e sentir o próximo (o outro como próximo). 
Tico também nos conta como, ao se envolver com o grupo de maracatu rural Piaba de Ouro, em Olinda, sentia uma força que partia da coletividade, do realizar uma brincadeira em conjunto:

“[...] essa força de estar em grupo e fazer um som único ali e sair, brincar... Aquilo ali fazia parte, né?! [...] Você entrar no maracatu rural, tá de caboclo de lança, fazer todo trabalho ali, fazer o bordado e tal e... Na hora de uma saída [desfile], você vê o maracatu montado e você, ali, no meio daquilo! Assim, é de uma força que você vê que nada vai lhe acontecer! Que nada de material, espiritual vai entrar ali dentro, porque o grupo tem uma força, sabe? E aí você sai desfilando com aquilo dali, nossa! [gesto de arrepio]"

O brincante adiante ressalta também a importância dos vínculos que estabeleceu com mestres maracatuzeiros, como Salú, Manoelzinho e Maurício. Mais do que frequentar os ensaios dos grupos, para Tico, existia uma relação afetiva, de trocas e aprendizados, em que os mestres passaram a constituir uma extensão de sua própria família. O narrador enfatiza que chegou a se sentir "adotado” por um deles:

“[...] não era só ir mais pro ensaio, sabe?! Era ir pro ensaio e por alguma outra coisa... Conhecer exatamente Maurício! [...] E com Salú, a relação foi mais doida ainda, porque Salú acabou me adotando. Assim, o meu sentimento é que ele me adotou, tem esse lado... E isso já abriu outro mundo! [...] Aí, conheci Manoelzinho [filho de Salú], que pra mim é meu grande mestre, assim. E aí comecei a ir pros interiores com Manoelzinho e comecei a ir pra reunião de maracatu rural. Aí, comecei a conhecer outros maracatus”.

Por meio das narrativas de nossos/as brincantes, observamos como esses vínculos com os outros vão fundamentando uma concepção de cultura popular como comunidade em suas trajetórias de vida. Assim, o brincar vai se configurando como 
espaço de comunhão; são trocas e relações estabelecidas em um meio comum, que configuram a própria brincadeira. Brincar revela-se uma espécie de força alcançada pelo corpo coletivo que, para Tico, é também um reconhecer de si próprio: é "essa comunhão, esse reconhecer de histórias... De quem sou eu”.

As contribuições de nossos/as brincantes sobre a força coletiva que os constituem nos fazem retomar as contribuições de Bakhtin (2008) acerca do corpo coletivo e, também, festivo da cultura popular. Acerca disso, Lipe faz um comentário importante em relação às festas que frequentava na roça quando criança:

“a gente [Lipe e sua mãe] ia muito nessas festas na roça, e as festas na roça sempre iam até altas horas! Então, eu faço muito uma conexão legal porque eu via minha mãe se divertir muito nas festas! Jogando baralho! [...] Então, minha mãe ia até altas horas na festa e eu ia com as crianças brincando também! Eu vejo que aquele lugar era um lugar de permissão, assim, de licença, onde a galera permitia se encontrar, comer, beber bastante, cantar, dançar, conversar, ouvir as histórias dos mais velhos".

O brincante descreve as festas na roça como um lugar de permissão/licença $\mathrm{e}$ encontro, em que se podia "beber bastante, cantar, dançar, conversar, ouvir". Era uma experiência da fartura, que nos remete às ideias de Bakhtin sobre a estética grotesca em que o exagero, como abundância (e não excesso ou sobra), contempla o corpo indivisível das expressões populares.

Para o autor russo, o corpo coletivolfestivo popular diferencia-se completamente do corpo individualista burguês (ver capítulo 3). Mas, paralelamente, esse corpo popular em nossos/as brincantes fortalece (e é fortalecido pelas) suas constituições subjetivas: um reconhecer de “quem sou eu”, como vimos em Tico. Aqui, 
vale lembrar que a constituição humana é necessariamente histórica e cultural (Vigotski, 2000).

Sobre essa dialética $e u$-social, é interessante perceber como Lipe discorre acerca da cultura popular enfatizando os processos de identificação. Ele diz:

“a cultura popular traz muita força a partir da identificação, né?! Das pessoas olharem e se verem naquilo ali que tá acontecendo! Então, elas participam da construção... Participam da história, né?! Conseguem se envolver de corpo e alma com aquilo ali, que ela tá vendo, porque ela se identifica!”

Lu também enfatiza a importância do meio social, do envolvimento com um ponto de cultura ${ }^{31}$ na constituição do "seu ser". Emocionada, ela narra:

"me envolver com o ponto de cultura foi um processo de resgate da minha própria identidade, de conseguir me ver. Então: 'ah, beleza, eu sou da periferia! E é isso mesmo! E eu tenho uma família que veio da roça, de trabalhadores! E é isso mesmo!' E isso é construção do meu ser, da minha identidade. É fazer as pazes mesmo com a minha história, com a minha própria história e... Então, o trabalho nos pontos de cultura foi isso, foi um trabalho de fortalecimento da minha própria identidade!"

Adiante, Lu conta que ingressar no Seu Estrelo também fez parte desse processo de valorização de si mesma, de sua história de vida. Segundo ela, foi uma trajetória que exigiu uma "cura de autoestima", pois a brincante inicialmente achava que integrar o grupo era algo "distante" de sua realidade:

“então era isso, eu via Seu Estrelo e pensava: 'nossa! Lindo! [expressão de ânimo, sorri] Mas eu, aqui, minha realidade é tão dura e tal! [expressão de desânimo, abaixa a cabeça]'. Sabe? Essa coisa de... Que é possível! Você pode também!... Então

\footnotetext{
${ }^{31}$ Os pontos de cultura são coletivos ou entidades que fazem parte do programa Cultura Viva, desenvolvido pelo Ministério da Cultura. Ver http://www.cultura.gov.br/pontos-de-cultura1 e http://www.cultura.gov.br/cultura-viva1.
} 
foi todo esse processo que eu contei, me trouxe esse sentimento, esse empoderamento, essa cura de, tipo assim, seja quem você é! E vai dar tudo certo, sabe?! Não negue o que a vida te oferece, sabe?! Então, esse aprendizado de 'aprender mesmo a receber'... É quase como se eu tivesse uma negação... De que o muito bom não era pra mim, entendeu? Eu interpreto assim mesmo, como um processo de cura mesmo”.

É interessante perceber como, nos três casos, a cultura popular é apresentada como uma dimensão de empoderamento de $s i$, de encorajamento e percepção de uma vida mais significativa em comunidade e a partir da própria comunidade/grupos. Contudo, de acordo com Lipe, nem sempre essa sensação de pertencimento é algo consciente e esclarecido, pois perpassa também por uma dimensão mais sensível e menos cognoscitiva (explicável). Ele relata que

“... essa identificação, muitas vezes, nem é uma coisa tão objetiva e clara, né?! É uma coisa mesmo de, muitas vezes, partir até de uma sensação... Você não sabe exatamente!"

Porém, ao se aventurar a explicar a importância do Seu Estrelo em sua vida, Lipe enfatiza tal dimensão sensível como algo “subjetivo e verdadeiro”:

“eu fui começando a ganhar com o Seu Estrelo a possibilidade de estar junto! Da gente imaginar uma coisa, chegar lá e apresentar! E ver, sentir a força daquilo ali... Sentir o resultado, sentir uma volta [reciprocidade], sentir uma comunhão, sentir um ciclo de informação, sentir que tá fazendo parte do mundo! Fazendo parte da evolução, fazendo parte do caminhar, das cores, da cidade, do crescimento espiritual também, né?! Do crescimento físico! Fui começando a ter essa sensação muito subjetiva e muito verdadeira! [...] Isso começou a participar de uma satisfação de vida, de felicidade mesmo, de alegria na vida, de acreditar nos caminhos, de acreditar em si mesmo". 
Nesse trecho, Lipe expressa enfaticamente os seus sentimentos, a verdade implicada em seus afetos — algo que emerge da/na sua relação com o próprio grupo que ele integra, o Seu Estrelo. Percebemos também que os argumentos do brincante perpassam por uma dimensão sensível, desvelando sensações obscuras que parecem não adentrar um campo racional. Em outros momentos, notamos que tanto Lipe quanto Tico relatam uma aparente dicotomia entre emoção e razão nas suas constituições como brincantes:

LIPE: Eu sinto isso mesmo! Que é uma coisa, assim, que... A partir do momento em que eu abrir o campo da sensação, o campo dos sentimentos mesmo, das emoções, pra além de racionalizar uma coisa ou colocar a coisa numa técnica [...].

TICO: Porque tem sentimento, não tem razão, é muito sentimento... Então você acaba se abrindo muito pra esse sentimento, né? Porque, muitas vezes, não tem muita razão o que você tá fazendo ou o porquê tá fazendo, sabe? É um sentimento [...].

Achamos importante evidenciar aqui que, na psicologia histórico-cultural, existe uma relação indissociável então razão e emoção. Sobre isso, Magiolino (2011) coloca:

parece ter caído no lugar comum a ideia de que razão e emoção são dimensões inseparáveis no/do psiquismo humano. [...] Diversos trabalhos vêm procurando trazer algumas reflexões sobre o papel da afetividade no funcionamento psicológico e na construção de conhecimentos cognitivo-afetivos” (p. 35).

Por essa via, o sentido (em sua dimensão ontológica, lembremos) é constituído na dialética cognitivo-afetiva. Contudo, destacamos o papel central das emoções na constituição dos/as brincantes, pois, conforme apontamos, elas estão no cerne do problema da psicologia da arte, em Vigotski (1999). Lembremos que, para o autor 
bielorrusso, "além de uma ação periférica, a emoção exerce ainda uma função central" (p. 264) no psiquismo humano, nas experiências estéticas suscitadas pela arte.

Logo, é interessante identificar como os/as brincantes enfatizam essa dimensão afetiva/emocional em suas trajetórias. Tico e Lu, por exemplo, relatam o impacto das sensações vivenciadas em suas primeiras experiências estéticas com os brinquedos populares. Segundo Tico, tocar tambor com os grupos de maracatu era algo que o encantava, alterando todo o seu corpo:

“a princípio, quando eu entrei [no grupo de maracatu], não tinha esse olhar tão do que era [a cultura popular], toda a profundidade... Era mais querer tocar, querer brincar! Era se encantar com aquilo, querer se encantar! [...] É engraçado como mexia, a princípio, também o tambor comigo, assim, como alterava inteiro o corpo! Essa força de estar em grupo e fazer um som único ali e sair, brincar... Aquilo ali fazia parte, né?!’ Já Lu nos revela a primeira vez que vivenciou as brincadeiras dos (com os) grupos Seu Estrelo e Pé de Cerrado ${ }^{32}$. Segundo ela, foi uma experiência "extracotidiana":

LU: “[...] Lembro da primeira vez que vi Seu Estrelo... Eu pirei o cabeção, né?! [risos]”

ANDRESSA: "Onde foi? Você lembra?"

LU: "Primeira vez que eu vi, foi no Teatro Nacional [Teatro Nacional Cláudio Santoro], na gravação do DVD do Pé de Cerrado."

ANDRESSA: "Sim! Em 2005, né?!"

LU: “Isso! E aí o Pé de Cerrado também! Foi a primeira vez! Foi a primeira ciranda que eu dancei, embaixo da lona de circo [gesto de grandeza com as mãos e

\footnotetext{
${ }^{32}$ Grupo artístico surgido em Brasília em 1999. Seus espetáculos integram “diversas formas de expressão artística e as mais plurais manifestações da cultura brasileira [...], trazem música, circo, dança, poesia, teatro e proporcionam uma intensa participação do público" (http://pedecerrado.com.br/sobre/. Acesso em: jun. 2015).
} 
expressão facial de alegria]... Aquela lona de circo e os Irmãos Saúde! ${ }^{33}$ Aquela energia, aquele brilho no olho! Eu falei: 'Meu Deeeeus! É isso que eu quero pra minha vida!' Por se identificar, né?! Porque, aí, tinha a ver com isso... Com esse lugar de achar o brinquedo na vida adulta! Então, a brincadeira, quando você é adulto, é esse lugar que te tira da energia cotidiana e te coloca num lugar da energia extracotidiana... E na cultura popular você tem isso, né?! Os adultos têm seus brinquedos! É uma capoeira, é o samba, é uma folia, é uma catira! Aonde a pessoa vai ali brincar, seja por devoção a um santo, seja por celebração, por festa... É um momento em que a pessoa sai da rotina, do cotidiano e entra nesse estado libertador, sabe?! Esse estado de presença. Onde você sai do automático, da vida cotidiana e entra, né?!"

O brincar adulto, conforme discorrem Lu e Tico, é definido pela força da energia, do encantamento, da satisfação de vida, da magia, do estado extracotidiano. Notamos, ao logo das narrativas, que esse brincar se diferencia substancialmente do brincar durante as suas infâncias, principalmente porque vai assumindo um caráter profissional: transforma-se em ofício/trabalho.

Nesse contexto, brincar é, simultaneamente, uma condição (humana, do ser) e uma construção (do fazer, eu me faço brincante), como ressaltamos na fala de Lu. Assim, para além de ser, brincante é uma espécie de fazer-ser (termo nosso). Acerca dessa constituição complexa, Lipe diz que não é em todo lugar, nem durante todo o tempo, que ele se sente brincante:

"na minha constituição, assim, como pessoa, participam muitas outras pessoas. Os outros interferem muito, participam muito do meu ser brincante, então, quando eu tô no meio [comum], tipo aqui no Seu Estrelo, né? Quando eu tô aqui,

${ }^{33}$ Dupla de palhaços do Circo Teatro Artetude, que integra os espetáculos do Pé de Cerrado (http://www.circoartetude.com/p/integrantes_28.html). 
com meus amigos, eu sinto que eu tô muito potente, que eu tô muito forte! Então aqui eu sou brincante mesmo! Me sinto bem livre! [...] Já lá [no circo], eu não me sinto tanto [brincante]!... Já lá é um trabalho interior que eu tô fazendo, sabe? [expressão de como se estivesse assimilando algo] Assim, na consciência, fico fazendo um trabalho mesmo! Porque lá já é o lugar onde eu sinto que eu não domino as ferramentas, dentro do circo, sabe?!”

Aqui, é interessante notar como, na constituição do brincante, o domínio de ferramentas comuns a um meio é importante. Assim, Lipe alega não se sentir "bem livre” em espaços (circo) que ainda não domina as ferramentas, tecnicamente. Isso parece dialogar com a própria origem da palavra arte (do latim ars), que remonta à técnica e que, segundo o dicionário Aurélio (Holanda, 2004), tem relação com habilidade/ofício. Como explica Coli (2008), no passado, uma obra-prima artística era "aquela que coroava o aprendizado de um ofício, que testemunhava a competência de seu autor" (p. 15).

Entre nossos/as brincantes, contudo, ressaltamos não apenas a habilidade técnica, mas a importância dos pares, de como estar entre amigos faz Lipe se sentir mais potente em seu brincar/ofício. Além disso, como já sinalizamos, para ele, fazer-se brincante abarca uma dimensão profissional e é uma espécie de trabalho artístico. Trabalho que foi, cada vez mais, dando sentido a sua vida, a ponto de fazê-lo abandonar o curso de Letras em que ingressara na universidade. Lipe narra:

“porque, aí, também o trabalho aqui [no grupo] foi ficando mais consolidado e eu fui vendo realmente esse caminho artístico, cultural, como um caminho alternativo de profissão, de trabalho mesmo! Um pouco difícil, porque a arte não é valorizada, então, tem que trabalhar muito pra ter uma vida digna! É um pouco difícil, 
mas eu comecei a acreditar, de fato, nesse caminho, né?! Então, eu desapeguei um pouco da história do diploma e tudo mais".

Tico, por sua vez, relaciona seu ser brincante com um sagrado ofício, em que o "período de férias" torna-se um momento de profunda angústia:

"pra mim, esse período de férias é o pior período que tem, porque eu não tô brincando! É um período em que eu fico angustiadíssimo, assim! Mas é bom que eu escrevo, tipo, vem mais figura de mito, vem mais coisa. É bom, legal dar uma descansada um pouquinho, mas assim... É um período que, quando volta, em fevereiro, quando a gente começa de novo, é um período que... Fuиu... Pronto! [respira fundo, aliviado] Tô de novo! Assim, não tô parado! Quando tô... [expressão de angústia, mãos sobre o peito] Então, as férias pra mim é um período que me dá, sabe?! [se encolhe, angustiado] Então, esse profissional pra mim é... Porque não tem, assim... [silêncio] Conversando aqui me vem várias ideias, sabe?! A gente brincando, me vem também! A gente tocando, me vem! É o tempo todo! O tempo todo me vêm coisas, assim, então eu tô praticando! Naquele momento, eu tô fazendo a minha profissão! É essa coisa do ofício, do sacrifício! Que é o sacro ofício, é o sagrado ofício né?! Ligado ao ofício, assim... Ofício é isso, né?! O ofício da gente é esse! Então, eu vejo muito a nossa profissão num sentido de ser brincante o tempo todo, né!"

Assim, fazer-ser brincante é uma prática que, para Tico, o permeia o tempo todo: “o tempo todo me vêm coisas, assim, então eu tô praticando!" Sobre o tema, Lu ressalta como foi importante a convivência com Chico Simões ${ }^{34}$ para a construção de um olhar profissional sobre a sua brincadeira. Ela diz:

"eu tenho muito o Chico como referência porque, de alguma forma, ele foi aquele cara que botou fé, sabe?! [...] Ele abriu essa possibilidade, ele falou assim:

\footnotetext{
${ }^{34}$ Brincante de mamulengo "e outras palhaçarias", coordena há mais de 30 anos o grupo Mamulengo Presepada, de Brasília (ver http://www.mamulengo.org/).
} 
'olha, se você quer, é possivel viver de arte! É possível viver da arte como um trabalho!',"

Segundo ela, esse processo foi fundamental para sua profissionalização, pois nem todo brincante faz da brincadeira o seu trabalho: "porque não necessariamente todo brincante precisa ser um brincante que trabalha!... Profissional”. Assim, a narradora diz que necessitou desenvolver um compromisso maior com seu brinquedo, na época, de mamulengo e de palhaçaria, anterior a sua entrada no Seu Estrelo. Para ela, fazer-ser brincante exige um comprometimento real com a brincadeira:

“já que é uma construção, então, eu vou me comprometer com esse instrumento! Então eu me comprometi com a minha palhaça, me comprometi com os bonecos!... Fui me comprometendo de, cara, levar isso não como um hobby que eu vou me comprometer nas horas vagas, mas como um trabalho. Claro que isso foi um processo, né?! [...] E aí a reflexão que eu fiz foi a seguinte: 'já que é pra trabalhar, eu vou trabalhar com o que eu gosto!' E aí eu entrei muito nessa reflexão mesmo de: 'o que que é o trabalho?' O trabalho é a minha energia mais preciosa, que é a minha energia de transformação do mundo! O trabalho é tudo aquilo que eu pego, manipulo e transformo".

$\mathrm{Na}$ fala de Lu, fica evidente que, por mais que todo mundo possa ser brincante (ou, como discorremos, público-brincante) durante uma brincadeira, existem pessoas que o são de forma bastante diferenciada e muito mais intensa: pessoas que têm o brincar como exercício de seus trabalhos, como ofício de vida.

Notamos, aqui, que a noção de trabalho, discutida pelos/as brincantes, parece se aproximar bastante da concepção ontológica de Marx sobre o termo (trabalho social), como algo que humaniza o "homem" (ver capítulo 1). É interessante perceber como Lu argumenta que o trabalho é "sua energia mais preciosa" de transformação do 
mundo e que, por isso, envolve um comprometimento verdadeiro. Isso também é observado na fala de Tico, quando afirma que é brincante o tempo inteiro.

Por isso, brincar, nesse contexto, envolve tanto uma energia extracotidiana como uma demanda de apropriação de técnicas e instrumentos que é trabalhada cotidianamente, conforme apontamos nas narrativas. Assim, brincar é um ofício que exige uma série de preparações que auxiliam os/as nossos/as brincantes a lidar com essas complexas transformações de estados — de cotidianos a extracotidianos, e viceversa. Sobre isso, Lu narra:

"hoje, eu me sinto uma profissional e, aí, hoje eu sinto que eu consigo me preparar, no meu dia a dia, me organizar pra tipo assim: 'beleza, agora é hora de eu ir lá e brincar!' E ter o meu ritual pra poder: 'pá! Beleza, brinquei'. Então eu fecho minha mala, guardo minhas coisas e vou continuar [gesto de abrir com os braços e de fechar]. Porque é isso! É um trabalho de muita exposição!"

Assim, percebemos que brincar exige um ritual profissional, de abertura e de fechamento da brincadeira, que não é um fechamento do ser brincante, conforme Tico argumentou. Veremos, a seguir, que esses rituais foram aprendidos e compartilhados no longo fio histórico-cultural das tradições populares. Tradições que carregam fortes heranças daquilo que já se passou, mas que, ao mesmo tempo, se inovam pelos intensos relâmpagos das invenções do povo.

\subsection{Eixo B) A relação entre tradição e inovação nas brincadeiras populares}

Existe, no Brasil, um debate muito recorrente sobre o risco de desaparecimento de algumas manifestações tradicionais, "principalmente pela dificuldade de renovação de seus participantes" (Veloso, 2010, p. 1). Contudo, para o professor e pesquisador 
Veloso (2010), atualmente, nota-se na realidade uma renovação constante dessas manifestações, como folias e catiras, pelo surgimento de novos integrantes jovens.

Sobre esse assunto percebemos que, para os/as nossos/as brincantes, a cultura popular, ao mesmo tempo que busca elementos do passado, em conexão com a ancestralidade, é constantemente renovada. Segundo Lu, integrar movimentos culturais e educacionais, como a Ação Griô, ${ }^{35}$ a fez "aprender que existe uma ancestralidade que acompanha”. Lipe, por sua vez, destaca o caráter inventivo da cultura popular:

"a cultura popular é um lugar de invenção, né?! [...] Como é a cultura do povo! Então, como o povo também vai mudando, a cultura também vai mudando! Porque se não, se não muda, vira museu com o tempo. Vai perdendo a identificação, as pessoas que vão crescendo já não vão mais fazendo essa relação que... Que o passado fez! Então, por conta disso, dessa criação, construção constante, essa coisa de aprender com o olhar de quem ensina... Quem chegar aqui com a disposição de aceitar a sugestão do outro, participa dessa construção constante!”

Para Tico, entender realmente o universo popular significa "querer estar pleno no mundo, querer estar ligado ao passado, mas estar lá na frente também”. Ele relata que o grupo Seu Estrelo busca sempre (re)inventar sua brincadeira, porém, assumindo os elementos mais antigos, que constituem sua nova tradição; como os maracatus e os cavalos marinhos (ver capítulo 4). Percebemos isso pelo próprio nome da sede do grupo, que parece jogar com as noções, aparentemente opostas, de tradição e de invenção, a saber: Centro Tradicional de Invenção Cultural.

Tico diz, também, que uma das características da cultura popular que o grupo sempre buscou enfatizar é a inventividade ou a dimensão inventiva:

\footnotetext{
${ }^{35}$ A Ação Griô desenvolve inúmeras atividades (culturais e educacionais) visando à valorização das tradições orais. Ver http://www.acaogrio.org.br/.
} 
“...de várias características da cultura popular, a gente resolveu tirar pra dançar a invenção. Então, é pesado também ter que estar dançando com ela, porque toda hora você tem que inventar um passo novo... Porque você tá dançando com a invenção! Então, o tempo todo você tem que estar se inventando, na hora da dança, assim [risos]".

Essa metáfora de dançar com a invenção é interessante porque o brincante prossegue argumentando que, devido à brincadeira do grupo ser constantemente (re)inventada, existe uma necessidade de desenvolver atividades diferenciadas, se comparadas a outros grupos tradicionais. Uma delas é o ensaio de botação de figuras (termo explicado no capítulo 4). Tico comenta que, em brinquedos como o cavalo marinho, por exemplo, já existe uma tradição em que os brincantes crescem vendo as figuras e aprendem a botá-las pela observação durante as próprias, e longas, brincadeiras. Assim, geralmente não existem ensaios de cavalo marinho, porque não há essa necessidade. Contudo, pelo fato de o Seu Estrelo criar uma brincadeira diferente, com elementos novos e peculiares à cidade de Brasília, o brincante nos esclarece que houve essa necessidade de ensaiar a botação de figuras. Ele relata:

"a gente tem que partir pra uma conquista... Que é diferente de um cavalo, que é diferente de um maracatu... Que a coisa já existia numa dimensão, né?! A gente não! A gente tava criando uma coisa, tava chegando na cidade, a gente precisava chegar nos lugares, precisava se apresentar... E, então, como é que se chega? Sabe?! A gente começou a ter que se produzir, porque não tinha espaço na cidade pra isso. E aí, em um determinado momento a gente tem que ensaiar, porque a gente tá criando a figura. Então, não é uma coisa de ter a figura, não é uma coisa que eu cresci e já tô sabendo quem é a figura. Não... a gente tá criando a figura". 
Aqui, é importante retomarmos as discussões sobre criação e autoria, em Vigotski e Bakhtin, em que a ideia de algo novo parte sempre de algo anterior e diz respeito ao contexto histórico-cultural ao qual um sujeito pertence. Assim, uma criação — no nosso caso, artística — nunca é exclusiva de um sujeito isolado, mas advém das tramas sócio-históricas que a impulsionam e viabilizam. Nessa conjuntura, que une o velho e o novo das tradições populares, chamaram-nos a atenção especialmente os relatos dos/as brincantes sobre as botações de figura durante suas brincadeiras, que o grupo tem denominado como teatro de terreiro.

Nesse contexto, observamos que existe uma preparação, uma espécie de ritual, que permite aos/às nossos/as brincantes adentrar estados extracotidianos, conforme sinalizamos. Nesses rituais, o corpo assume importância central, e é exatamente sobre esse aspecto que trataremos a seguir.

\subsubsection{A figura e o corpo: rituais no/do fazer-ser brincante}

Em inúmeras brincadeiras populares, os rituais de preparação são fundamentais. Para a pesquisadora Gomes (2007), os rituais têm "a função de ajudar as pessoas a retomarem suas memórias [...]. São essenciais, porque sem eles a brincadeira não se realiza" (p. 65).

Conforme $\mathrm{Lu}$ nos relatou, ela se entende atualmente uma brincante profissional, na medida em que também foi adquirindo suportes e meios para "abrir e fechar a brincadeira". Tais suportes são, na realidade, rituais que preparam o início e fechamento de um brincar e que, ao mesmo tempo, fortalecem sua constituição como brincante.

É interessante relembrar também que, para Lu, ser brincante “é um trabalho de muita exposição”. Percebemos que, nessa exposição, o corpo é um elemento essencial, 
pois tudo que se evidencia ao outro (e a si) é viabilizado pelo/no próprio corpo do/a brincante; a figura é o próprio corpo transfigurado. De fato, existe uma relação indissociável entre o corpo e a figura no brincar.

Por esse viés, o corpo é complexo e assume diferentes dimensões - entre elas, ressaltamos as memórias corporais ancestrais que fundamentam as brincadeiras populares. Sobre isso, Gomes (2007) enfatiza que as práticas tradicionais "possuem uma linguagem simbólica e subjetiva organizada como registros que preservam a memória do corpo” (p. 64). E essa memória é também particular e coletiva (Smolka, 2000).

Tal dimensão corporal e ancestral da memória é observada nos relatos de Lu sobre sua atuação em diferentes contextos: no mamulengo e no teatro de terreiro. Neles, notamos que a figura e o corpo assumem configurações específicas, de botar e de vestir:

"é que a gente tem essa relação com os bonecos [no mamulengo]... O Babau $^{36}$... A escola do Carlinhos Babau tem essa relação muito, digamos assim, ritualizada com os bonecos. Tem uma coisa, ali, do sagrado com o boneco que é isso que a cultura popular tem... O brinquedo, ele é!... existe uma relação de cuidado, de sagrado com o brinquedo... Então, pensar assim, que aqueles bonecos que a gente brinca, aqueles personagens que eu entro em contato, são figuras... Como no Seu Estrelo, as figuras no Seu Estrelo a gente veste, a gente é o boneco, né?! No mamulengo você bota o boneco [sinal com as mãos, de 'vestir o boneco com as mãos']. Você projeta a figura, o objeto... E... [silêncio]. Então, os bonecos, eles têm... Eles têm uma vida! Por quê? Porque aquelas personagens estão sendo construídas há muito tempo, por muitas pessoas. O que a gente recebe... Então, um Benedito, um João Redondo, um Boi [figuras] é uma herança de uma construção que vem

\footnotetext{
${ }^{36}$ Carlinhos Babau é um mestre mamulengueiro, criador da companhia Carroça de Mamulengos (fundada em Brasília, em 1977). Ver http://carrocademamulengos.org/integrantes/.
} 
ancestral. Então, é ter essa reverência, mesmo! Tipo, pra mim, os bonecos são muito maiores do que eu!"

Notamos, ainda, que para a brincante as figuras são vivas: “o brinquedo, ele é! [...] Então, os bonecos, eles têm... Eles têm uma vida!’. Vida que abarca heranças ancestrais no fazer-ser da brincante. Ela prossegue:

“... então, pra mim, eles [os bonecos] que [abre os braços]... Esse abrir, pra mim, é nesse sentido, que essa força toda, de todos esses mestres, de todas essas pessoas que trabalharam pra que esses bonecos pudessem chegar até a gente, tudo isso tá simbolizado no brinquedo! O Chico [Chico Simões] fala isso: ‘Cara, não sou eu que levo os bonecos pra viajar, eles que me levam!' E é isso! Porque os bonecos são muito maiores do que nós, né?! Mestre Solon ${ }^{37}$ falava isso: 'o boneco é anterior ao homem'. [...] Se você pensar, até pelas mitologias... Deus fez lá o bonequinho de barro e, aí, soprou a vida... [sopra a mão]. Nas mitologias africanas, você também tem essa reverência do boneco [...]. Então, existe essa... Existe um mistério, um sagrado, aí, nessa relação com esses bonecos".

Contudo, é importante destacar que a vida do boneco é, na realidade, a vida que o boneco simboliza e, mais ainda, a vida que se mobiliza em torno do boneco (objeto simbólico) e do brinquedo que ele abarca. Como Lu coloca, ao citar Chico Simões, são os bonecos "que me levam pra viajar", que abrem espaço para os/as brincantes passarem: “foram os bonecos que abriram o caminho pra eu passar, sabe?!”. A força do boneco (da figura) está em toda a herança que ele simboliza e que vai muito além da vida de um único brincante, por isso ela é uma força coletiva e histórica.

\footnotetext{
${ }^{37}$ Mestre mamulengueiro de Pernambuco (1920-1987).

Ver http://www.mamulengo.org/artigos/comapalavramestresolonalvesdemendonca
} 
De forma parecida com Chico Simões, Tico argumenta que "[...] a figura tá na frente, a gente não traz a figura, é a figura que leva a gente! A figura leva a gente quando a gente brinca, né?! Não sou eu que tô levando a figura, a figura tá na minha frente!"

Essa construção simbólica, que abarca as figuras, assume também uma dimensão sagrada para os/as brincantes, em que "o boneco é anterior ao homem”, "um mistério”. É interessante perceber isso na fala de Lipe, quando ele enfatiza o seu brincar como uma religião:

“depois que eu aprendi, assim, esse conceito da palavra religião... Pra mim, quando eu falo de religião, é falando dele mesmo... De religar ao mundo invisível, sabe?! Porque tem um tempo, remoto, onde esse mundo invisível, o mundo dos deuses, dos seres imaginários, e esse mundo que a gente vê, eles eram coisas coladas! Não eram distantes. Assim, como a gente fala hoje, sei lá, de Deus, dos santos, num outro patamar, numa outra dimensão, não é?! Uma coisa distante, né?! Fica láaaa... Distante! Houve um tempo em que essas coisas não foram distantes, foram uma coisa junta e, aí, hoje a gente se afastou. Então, a gente hoje precisa religar novamente, né?! Então, religião pra mim é isso: é chamar esse mundo do invisível pra mais perto! Pra religar, reaproximar, né?! E eu, com o Seu Estrelo, aqui, é isso que eu sinto desde o começo. [...] Eu sinto que é uma conexão com esse mundo invisível, das energias... Eu sinto isso mesmo!"

Essa concepção do termo religião como religação também é discutida por Veloso (2010). Segundo o pesquisador,

a compreensão que tínhamos, anteriormente, era a de que este sentido de religare era a "religação ao ser original", ou a Deus, em outras palavras. Hoje, porém, passa a ser algo mais complexo a leitura que podemos fazer deste 
termo: é a religação ao outro por várias representações simbólicas, desde as religiões propriamente ditas, as imagens e rituais católicos, os cultos protestantes, os candomblés ou diversas formas de totemização, até outras mediações mais contemporâneas. O que pode se dar por uma imaginária relacionada a visualidades, concretas ou não, e a práticas e comportamentos que abrem possibilidades de convivências societais baseadas naquele sentido de estar juntos, sempre verbalizado pelos participantes das folias. (p. 5, grifo nosso)

Notamos que, na narrativa de Lipe, religar-se tem aproximação com uma dimensão religiosa/ritualística, de conexão com um “mundo invisível, das energias". Mas também devemos enfatizar que tal ritual só é possível pela dimensão coletiva, pelo fio das tradições, que o brincar, nesse contexto, comporta.

Assim, ser brincante abarca necessariamente o sentido de estar juntos, ressaltado por Veloso (2010), que diz respeito a um relacionar-se com os outros, como enfatizamos no eixo anterior. Mas, nas narrativas de nossos/as brincantes, percebemos que esses outros possuem configurações bastante variadas - carnais, espirituais, mestres/as, entidades ancestrais etc. —, evidenciadas na relação corpo/figura.

O corpo é, desse modo, um elemento multiforme: físico e particular, com seus gestos, suores, danças, sonoridades ímpares; coletivo, das tradições populares, carregado de histórias, festejos, compartilhas, seres imaginários; e, também, sensível, espiritual, com rastros vivos de memórias, emoções etc. Isso parece dialogar profundamente com as contribuições de Bakhtin (2005) sobre a dimensão bicorporal da estética grotesca, presente nas expressões populares. Lembremos que, para o autor, tal estética possui uma qualidade dual, que incorpora os aspectos sérios e cômicos, espirituais e carnais, do mundo (ver capítulo 3). 
Ainda sobre essa relação corpo-figura, Lu afirma que botar figura é uma atividade que conecta passado e presente, numa rede geracional. A brincante diz:

“e, aí, eu penso nessas figuras mesmo como essa ancestralidade... São esses mestres que brincaram no passado e que continuam aqui! Aí, é isso, física quântica! [risos] Pô... Mil possibilidades da gente explicar! Tudo que aconteceu, lá no passado, tá acontecendo aqui também. Esses mestres estão aqui também. Quando a gente toca o tambor, a gente canta e tudo... Que essa é a experiência da cultura afro-brasileira de terreiro: a gente toca e toda a corrente vem!... [Botar figura] É... [silêncio]... $\dot{E}$ brincar com essa consciência, cara! De que eu tô a serviço, sabe?! A serviço dessa corrente... Existe uma ancestralidade brincante, sabe?! Existe uma ancestralidade palhaço! [emociona-se] E essas pessoas se comprometeram profundamente para que essa brincadeira pudesse continuar! Sabe?! Quando eu penso nisso... Quando eu penso nos mestres que viveram toda a sua vida, passando uns perrengues, altos e baixos e tal, mas tipo... Pra poder ensinar pro seu filho, pra ensinar pro ciclano, pra poder... Pra coisa continuar! Pra poder chegar [junta as duas mãos sobre peito, como se tivesse chegando até ela], até hoje, na gente, entendeu?! Então, é isso assim! Isso é uma coisa que a tradição me ensina!...”

A brincante prossegue bastante emocionada, relatando que inclusive o nome de seu filho, Inácio, "[...] veio numa roda de capoeira! [chora]. Era uma música de capoeira: 'Inácio, Inácio!'. E era uma roda de Iemanjá... Aí, tipo, rolou aquela conexão e eu falei: 'é Inácio!’ [sorri]. [...] Hoje, eu brinco [coloca as mãos sobre o peito] com muita consciência de que eu tô brincando sério! Tipo... Eu tenho um filho pra criar, eи quero ensinar isso pro meu filho, eu quero que meu filho também brinque! Eu tô passando e dando passagem... O Tico também fala muito disso, né?! Então, eu senti que ter um filho me fez conectar ainda mais com a tradição e principalmente, 
assim... Sendo mulher dentro dessa tradição! [...] E eu quero continuar brincando nessa condição, sendo mãe! E aí um ganho da modernidade é essa discussão da questão de gênero. Então, eu me vi muito dentro dessa discussão toda, da questão de gênero inclusive”.

É interessante como Lu discute as questões geracionais e, também, de gênero ${ }^{38}$ à luz das tradições populares: "eu senti que ter um filho me fez conectar ainda mais com a tradição e principalmente, assim... Sendo mulher dentro dessa tradição!’. Notamos que a maternidade fortaleceu o seu brincar, quando ela narra: "hoje eu brinco [coloca as mãos sobre o peito] com muita consciência de que eu tô brincando sério!"

Ainda sobre o trecho supracitado, em que a brincante enfatiza existir uma "ancestralidade brincante" que constitui os brinquedos populares, identificamos também que há aspectos bastante específicos à botação de figuras no contexto do teatro de terreiro. Investigar essas características faz parte de nossos objetivos específicos, visto que nossos/as brincantes atuam nesse campo, onde, segundo Lu, “a gente toca $e$ toda a corrente vem!"

\subsubsection{O brincar no teatro de terreiro: a tradição como invenção}

Buscar entender a produção de sentidos na/da constituição dos/as nossos/as brincantes nos fez percorrer necessariamente os caminhos de seus brinquedos e brincadeiras. No grupo Seu Estrelo, as brincadeiras de roda são denominadas de teatro de terreiro. Conforme apontamos na discussão metodológica, esse termo é bastante singular ao grupo. Por isso, buscamos esclarecê-lo pelas narrativas dos/as próprios/as brincantes.

\footnotetext{
${ }^{38}$ Aqui notamos as lutas e contradições travadas no interior da própria cultura popular, dessa forma, cabe ressaltar que ao mesmo tempo em que ela "fortalece" em alguns aspectos, ela também "oprime" em outros. Não se trata de um contexto isolado do resto do mundo ou uma "ilha da fantasia", vale enfatizar que assumimos uma perspectiva teórica dialética, que assume a contradição o tempo todo.
} 
Segundo o fundador do Seu Estrelo, Tico, no início da brincadeira do grupo era difícil dar nome às suas experiências estéticas, principalmente, pelo caráter peculiar de suas criações. Ele narra:

“a gente começou a brincar, brincar... E, a princípio, era difícil definir, né?! Porque assim: o que era, exatamente, a gente surgindo com um mito novo? Era até difícil quando a gente falava que tava criando um mito ${ }^{39}$, era... [silêncio]. Se hoje, dez anos depois, ainda é! Imagine no primeiro ano?! Que nego nem sabia que mito era! Se hoje ainda rola um estranhamento... No começo, a gente falava: 'a gente tem um mito', 'que porra de mito?', [respondiam]... O grupo tava surgindo com um mito, com um som novo [o samba pisado] dentro de Brasília, mas que era tradicional, achando que era cultura popular! Mas não era cultura popular, porque tava em Brasília! [tom irônico] E aí Brasília tem todo o seu estigma já de 'ser Brasília', e aí 'o que era isso?'. Então, era muito assim, mas foi! A coisa foi indo! E aí a gente tentava se definir um pouco... Aí teve um determinado momento que era um teatro de rua, não era um teatro, e aí 'o que é que era?',"

Entre as inúmeras indagações apontadas por Tico sobre a tentativa de definir a brincadeira do grupo, é interessante destacar os desafios enfrentados em relação à aceitação do outro: "era até difícil quando a gente falava que tava criando um mito, era... [silêncio]. Se hoje, dez anos depois, ainda é! Imagine no primeiro ano?!” Sobre isso, o brincante prossegue alertando sobre o "estigma" que se tem da cidade de Brasília, como um lugar que, para muitos, ainda é sem tradição, sem cultura popular.

Ao buscar definir o brinquedo do Seu Estrelo como algo peculiar à cidade, Tico se remete também às suas experiências em Olinda. Conforme apontamos, nenhuma invenção parte do nada, pois é sempre fruto de um dado contexto histórico. Assim, ele

\footnotetext{
${ }^{39}$ Trata-se do Mito do Calango Voador. Ver a seção Breve histórico do grupo, no capítulo 4.
} 
narra que o termo teatro de terreiro foi apropriado/ressignificado pelo grupo devido à influência do cavalo marinho, de mestre Salú:

“antes de começar o Seu Estrelo [durante sua juventude]... Assim, conhecendo Salú, ele não tinha claro um conceito, mas claro que o conceito vinha pelo que ele definia! Porque a pessoa perguntava: 'ah, Salú, o que é um cavalo marinho?' Aí ele falava: 'ah, é um teatro de terreiro!' 'Mas o que é um teatro de terreiro?' 'É um cavalo marinho!' [risos] Tipo, era isso assim! Então, [era] pelo olhar do que, pra mim, era um cavalo-marinho que eu tentava imaginar o que era teatro de terreiro! Assim, mas não era uma coisa... Pelo olhar do que era o cavalo, mas não tinha um conceito do que era teatro de terreiro assim: 'ah, teatro de terreiro é por causa isso!' Claro que o cavalo marinho já dava uma dimensão do que Salú dizia! Era um teatro de terreiro, um teatro de quintal, assim, um teatro pras pessoas, pra quem brincava! Teve um determinando momento que a gente [Seu Estrelo] foi brincando e que eu percebi que já não era um teatro de rua o que a gente tava fazendo, que a gente não consegue intervir. A gente não chega em um espaço e... Acontece! A gente tem que preparar o espaço, a gente tem que preparar aquele lugar!... É bom convidar as pessoas! Pras pessoas virem já sabendo minimamente que vão sentar pra ver as figuras chegando, que é essa formação!”

Percebemos que o teatro de terreiro traz essas características de preparação de um espaço e das pessoas, que vão “ver as figuras chegando”. É, também, uma brincadeira “de quintal [...], um teatro pras pessoas, pra quem brincava!” Desse modo, conforme sugerimos anteriormente, o brincar no contexto das expressões artísticas populares parece abarcar outra forma de exotopia.

Nesse contexto peculiar, o teatro de terreiro parece envolver também uma dimensão religiosa e ritualística, pois, resgatando as narrativas de Lipe, ser brincante é 
um trabalho de religação (religare) ao "mundo invisivel”. Por essa via, ele narra que o teatro de terreiro se assemelha aos rituais do candomblé:

“te-a-tro de ter-re-i-ro, né?! Então, misturam duas manifestações, dois aspectos de manifestações que acabam remetendo a lugares diferentes... O terreiro, que é esse lugar onde mora a espiritualidade, né?! Onde tem muito esse segredo, mistério, a magia; e o teatro, que já tem um lado mais técnico, assim, uma história da civilização... [...] Quando você vai num terreiro de Candomblé, é bem essa mistura mesmo! [...] Você já vê uma coisa bem visceral, assim, você vê... Essas pessoas que recebem os santos, que têm uma abertura mediúnica, né?! É uma coisa tão visceral, assim, já religiosa..."

Lu também enfatiza tal perspectiva religiosa quando relata que o trabalho no grupo é uma espécie de "jardim de infância da espiritualidade”:

"outro dia eu tava conversando com alguém, que eu tenho feito a seguinte leitura: o trabalho do Seu Estrelo é quase como se fosse um jardim de infância da espiritualidade, sabe?! Porque é quase como se você estivesse ensinando as pessoas a lidarem com essa energia, que num terreiro é um trabalho ali sério e tal, direcionado pra espiritualidade. Aqui, a gente fica tipo brincando. Como se estivesse ensinando as pessoas a se familiarizar com essa energia do terreiro, entendeu?! A gente traz essa energia do terreiro, só que de uma forma brincante! Que nem quando, sei lá, você vai ensinar um alfabeto pra uma criança, você vai ensinar brincando, né?! É uma pedagogia! Ela aprende muito mais tranquila, sem traumas... E, espiritualmente, a gente tá ali brincando, ensinando as pessoas... Eu sinto que quando a gente abre uma roda as pessoas vivem uma experiência espiritual, mas num nível da brincadeira! É isso! Porque nem todo mundo que assiste uma roda, assiste com uma consciência espiritual, entendeu?! E assim como... Eu nem sei se todo mundo que faz, também faz. 
com essa consciência. Mas eu sinto que as figuras estão ali, com esse objetivo, cara! De verdade, tipo: 'a gente tá aqui deixando vocês experimentarem um pouquinho do que que é um terreiro' [cochicha, como se fosse as figuras falando]. Entendeu?!"

A conexão entre religião e teatro de terreiro, no Seu Estrelo, também é percebida na fala de Tico. Para o brincante, foi durante um encontro com uma entidade, num terreiro de candomblé, em Pernambuco, que ele percebeu que deveria voltar para Brasília e dar continuidade ao mito/brincadeira, já iniciado, do Calando Voador (ver histórico do grupo). Ele diz:

“[aconteceu de], dentro do terreiro, uma figura chegar, uma entidade, e falar: 'tá sabendo que teu lugar é lá [em Brasília], né? Tá sabendo que teu espaço é lá, tua missão é lá, volta pra lá! Você tá procurando uma coisa aqui que você já sabe que não é, né?' E isso também me abriu muitos olhos!... Eu falei: 'então vou voltar, né?!' [...] Aí, é pedir aos Orixás pra acompanhar e, então, voltar!... [Ele prossegue narrando a entidade] 'Pelo mito, por causa da história que tu criou, tem duas entidades que tão te acompanhando'. E aí eu vim buscar isso, essa é a missão! O encantamento já não tava lá [em Pernambuco], as coisas já não tavam lá. Assim, a missão já não era aquilo! E foi meio esse empurrão que o terreiro deu, assim, de falar: 'seu lugar tá lá [referindose a Brasília], não é mais aqui!',

A importância do terreiro, na constituição do grupo, é observada também nas narrativas dos/das brincantes sobre a botação de figuras. Conforme apontamos, as figuras (os bonecos etc.), nas brincadeiras populares, possuem uma ancestralidade. No teatro de terreiro, percebemos que, além da dimensão ancestral e religiosa, há uma configuração peculiar da figura: ela é vestida, como Lu enfatizou. Sobre isso, destacamos outro trecho de sua narrativa, em que ela fala que a exposição dos/as brincantes varia de acordo com as características de cada brinquedo: 
LU: “...Por exemplo, o mamulengo, eu vejo, que é uma coisa mais leve, em algum sentido... Porque o brincante não se expõe tanto, sabe?!”

ANDRESSA: "Como é isso?"

LU: "Eu falo porque eu acompanhei o mamulengo de perto e... Eu fui casada com um mamulengueiro, né?! A gente brincou junto muito tempo, o Thiago, do Mamulengo Fuzuê. E eu via... Não é que é mais tranquilo! Mas você se expõe um pouco menos. Os bonecos, eles realmente... [gesto para cima com as mãos, imitando os bonecos em cima do palco]. Energeticamente, mesmo, sabe?! Você não se expõe tanto, sabe?! Não sei... Existe um resguardo maior do brincante, porque quem bota a cara a tapa é o boneco!"”

Já no teatro de terreiro existe uma relação de “maior exposição”, pois é o corpo, por inteiro, que se veste, concretizando a figura. Lu continua: "as figuras, no Seu Estrelo, a gente veste. A gente é o boneco, né?!". Nesse vestir, os/as brincantes sinalizam que há toda uma preparação para que se possa efetivamente vivenciar a figura. Os ensaios, como já abordamos, fazem parte desse preparo. Segundo Lipe,

"a gente não depende de projeto ou de ter uma apresentação marcada pra ensaiar, a gente ensaia primeiro! Antes de ter uma apresentação, independente de ter uma apresentação, a gente ensaia”.

Para o brincante, as figuras são constituídas nesses encontros. Lipe enfatiza, adiante, que neles há um processo de criação coletiva:

"uma coisa, assim, que foi um pouco do que eu peguei desde o começo [do grupo]... Que é o aprender as coisas com um olhar de querer passar, de querer ensinar! Por ter um grupo, aqui! E as pessoas se juntarem, aqui, e cada um vir pra propor alguma coisa, né?! Cada um vir sabendo que vão ter outras pessoas, aqui, pra gente construir alguma coisa junto. Então, cada um pode trazer alguma coisa de algum 
lugar! [...] Que nem você, na sua vida, você não recupera várias coisas na sua história? Nas suas referências? O personagem também! Tipo, em um ensaio que ele [personagem] veio aqui... Que, como os ensaios é isso.... é coletivamente.... Você vem e coloca o palhaço, outra pessoa vem e coloca o palhaço. Então, cada um traz suas referências, as suas vivências pro palhaço. E, de repente, alguma coisa que você colocou... Eu vi alguma coisa legal ali, aí eu pego a sua coisa, misturo com a minha e coloco! [...] A gente fica aqui, vem pra cá ensaiar e, nesses ensaios, a gente vai dando força pra figura, né?! Construindo a vida dela e misturando a vida dela com a nossa, né?! Porque ela não é outra coisa senão parte da gente, né?! Então, a gente vai dando força, vai construindo ela."

Lu também enfatiza essa questão da criação coletiva das figuras em sua narrativa:

"então, é toda essa troca energética ali, que é uma mistura de uma imitação, é também uma apropriação, é uma releitura e tal! Que é o processo da construção colaborativa, não tem exatamente um criador... A parada [a brincadeira] vai meio que se criando junta! O Tico idealiza a coisa, aí cada um que bota [a figura] traz um elemento. Então, é isso! A energia da figura, ela fica ali, e ela vai se disponibilizando à medida que você se disponibiliza também! Vai rolando uma troca mesmo."

Mas, apesar da necessidade de ensaiar do grupo, Lipe relata também um episódio sobre a primeira apresentação do Seu Estrelo, que parece abarcar uma dimensão mais subjetiva (sensível) do botar figura. Ele diz:

“... a primeira apresentação do Seu Estrelo já foi um processo de catarse em mim, assim, forte demais! Porque a gente não chegou a ensaiar exatamente o que ia falar no momento da apresentação, e chegou na hora da apresentação, foi assim: 'aaaaaah' [abre os braços]... O Seu Estrelo, a figura, chegou mesmo, sabe?! Falei 
várias coisas que eu não tinha nem planejado! Na hora, eu comecei a falar, a brincar com o pessoal... Assim, eu comecei a ver... E ficar muito à vontade! E só isso aí já foi marcando na minha história emocional... Coisas que não se esquece jamais, né?!”

Sobre essas “coisas que não se esquece jamais”, catárticas, que vão marcando a constituição de nossos/as brincantes, Lipe narra ainda uma vivência mediada pelo brincante Zé Regino. ${ }^{40}$ Segundo ele, foi um dos primeiros exercícios realizados nos ensaios do grupo, denominado de dança pessoal:

LIPE: “...E aí, os primeiros exercícios foi com o Zé Regino... Os primeiros exercícios que eu fiz, aqui, com o Seu Estrelo... De dança pessoal, onde a gente ficava cinco horas dançando e o Zé Regino ia conduzindo a partir de um terreiro... Eu fechava os olhos, eu começava a me movimentar e ele ia conduzindo imageticamente, coisas!"

ANDRESSA: "O Zé Regino era do grupo?”

LIPE: "Não, ele conheceu a gente e viu que a gente tava começando a trabalhar. E como ele já tá nesse caminho há um tempo, veio propor um exercício. E já foi logo o exercício de construção do terreiro próprio, do terreiro pessoal, sabe?! Então, esse exercício, até hoje, nas oficinas que eu faço, eu retomo ele constantemente. Porque é isso: é você pensar nos seus valores, colocar, na sua frente, pra onde você tá indo, qual é sua meta, qual o é seu objetivo, o que você tá querendo alcançar... O que você tá querendo com isso, qual é a sua missão, o que você acredita com esse caminho... E aí, ele [Zé] construiu a história de uma festa: do seu lado direito, você coloca o que você quer que tenha nessa festa, do lado esquerdo, o que você não quer que tenha na festa e, atrás de você, todos os seus princípios, fundamentos, suas verdades... Aí, você coloca num estandarte [as suas verdades] e levanta o mais alto possível e, a partir daí, você vai pro seu norte, pra sua meta!"

\footnotetext{
${ }^{40}$ Palhaço, ator e diretor de teatro, residente em Brasília. Ver http://zeregino.blogspot.com.br/.
} 
No trecho, identificamos como a festa, vastamente concretizada nas brincadeiras populares, permeia o imaginário ${ }^{41}$ dos/as brincantes; como um contexto em que eles/as colocam suas metas e as levantam, "o mais alto possível”, em um estandarte. Essa metáfora da festa parece dialogar com as ideias de Bakhtin (2005) sobre a dimensão festiva da cultura popular, que viabiliza uma segunda pele ou uma segunda vida para o povo (ver capítulo 3). Contudo, aqui é interessante observar que $a$ festa popular, como expressão estética do povo, é reconfigurada "imageticamente" como um "terreiro pessoal" onde os ideais de vida dos/as brincantes vão sendo trabalhados. Nesse contexto metafórico, sugerimos que o sentido da festa é, também, o de encontrar-se consigo mesmo, com o seu norte, a "sua verdade".

Tico, por sua vez, evidencia que o imaginário presente nas brincadeiras populares — seus mitos, “causos', figuras encantadas — é um "lugar” real, "onde a gente vive”. Ele diz:

“...quando a gente abre a roda, é esse conectar de lugar, dessa junção que tem entre a gente e a Celestina ${ }^{42}$, sabe?! Esse imaginário, também, do brincar! $\boldsymbol{O}$ imaginário como um lugar, mesmo, tão real quanto esse lugar que a gente vive”.

Veremos, no eixo $\mathrm{C}$, que a relação entre o real e o imaginário contempla também as formas de atuação política do Seu Estrelo. Por enquanto, é interessante discutirmos outro aspecto que caracteriza profundamente o teatro de terreiro: a importância da preparação do espaço da brincadeira (o terreiro). Acreditamos que essa é uma atividade fundamental na constituição dos/as brincantes, pois, na primeira etapa de nossa pesquisa, observamos discussões recorrentes sobre o assunto. Numa delas, por

\footnotetext{
${ }^{41}$ Utilizamos o termo imaginário referindo-nos a uma dimensão imaginativa que reflete e refrata as tradições populares: o imaginário do povo que cada brincante 'carrega' e compartilhada.

${ }^{42}$ Terra sagrada onde moram as figuras (ver seção Breve histórico do grupo, no capítulo 4).
} 
exemplo, o grupo questionava se o terreiro da brincadeira comportava apenas a área da $\operatorname{roda}^{43}$ (pintada no chão) ou ia além, abarcando outros ambientes.

Figura 20 - Roda de giz desenhada no Beco Cultural; e Figura 21 - Roda pintada na casinha
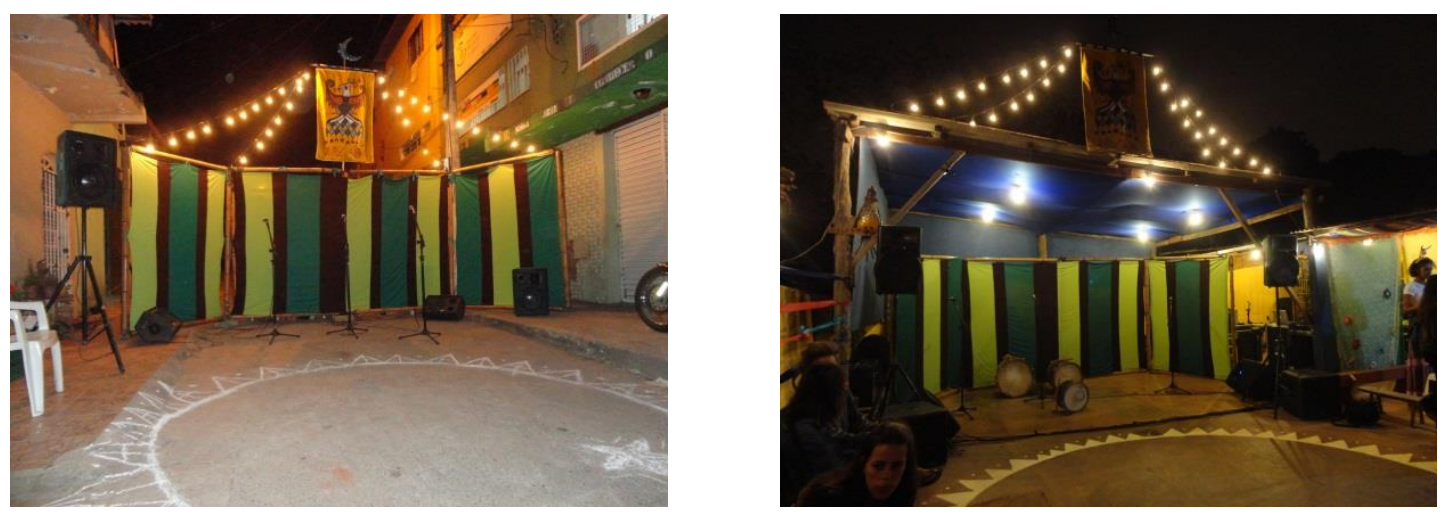

Antes da brincandeira começar a rodar, outra roda já encontra-se no chão do terreiro. Fotos do acervo da pesquisadora - 2013

Ao rediscutirmos o assunto nas entrevistas, notamos que o terreiro é também uma conexão de rodas, “um umbigo do mundo”. Sobre isso, Tico diz:

“... a gente sentiu que tinha que ter uma preparação, que não era só intervir, não era só chegar no espaço... Ao mesmo tempo, essa é a importância do terreiro, esse lugar como umbigo de mundo, mesmo! Esse lugar de onde tudo surge, onde tudo é contado, essa relação pra mim de uma roda que tá [acontecendo] aqui, ela se conecta, também, com uma roda lá, na Casa da Rabeca ${ }^{44}$... Sabe?! Esse umbigo!...”

Nessa preparação do espaço, os/as brincantes dizem que a figura não chega em todo lugar, logo, não é em todo lugar que a roda acontece. Para as figuras chegarem, há a necessidade de estabelecer uma relação de cuidado com o espaço e com as pessoas (público-brincante) que participam da brincadeira. Para Lipe, “...não é toda ocasião que a figura chega, não. A figura depende de algumas condições, né?!” Ele prossegue:

\footnotetext{
${ }^{43}$ Existem pelo menos duas formas de conceber a ideia de roda no grupo: como a brincadeira/espetáculo e como uma imagem desenhada no chão, onde as figuras se apresentam. Ambas são, a nosso ver, complementares.

${ }^{44}$ Espaço cultural fundado por mestre Salú (Olinda, PE).
} 
"então, a gente tenta trazer o teatro pro terreiro, e levar o terreiro pro teatro, assim... Então, quando a gente vai pro teatro: 'beleza, né?! Aqui é nosso terreiro!’ Não tem todos os símbolos que a gente pode colocar aqui [na sede do grupo], mas a gente pode levar pra lá algo, também! Não da mesma forma, mas muita coisa a gente pode levar e procurar trabalhar esse lugar [o teatro] também! Pra que ele vire esse lugar, com essa energia [do terreiro], né?! Com essa atmosfera, com esse contexto, já... esse contexto da apresentação... A pessoa [que irá ver a roda] já entra no lugar e, antes da apresentação começar, ela já entra na apresentação! Porque a apresentação já começa no espaço, né?! Então, quando a pessoa chega num lugar, já começou, né?! Já começa a ter uma coisa pendurada ali, já tem uma pessoa distribuindo um docinho, que é um docinho em formato de estrela!... Então é isso aí! A pessoa já entra comendo estrela! De repente uma figura lá [na roda] retoma aquilo: 'ah, quando vocês entraram comendo estrela, eu vi você comendo estrela!' Aí a pessoa: 'caraca, eu comi estrela!' Então, né, já é um outro conceito da apresentação! No teatro de terreiro, então, tem esses elementos todos!”

Quando a roda acontece e as figuras entram, o improviso ganha espaço. Para Lipe, fazer-ser brincante no teatro de terreiro requer mais que um caminho cênico (de ensaios) já traçado, exigindo, principalmente, uma abertura para o agora; o momento em que os umbigos das tradições populares se conectam e se reinventam, ampliando a sua longa extensão ancestral:

"você tem um caminho cênico já traçado, mas no meio desse caminho, você tem várias aberturas pro agora acontecer, pro acaso, pra você poder segurar o acaso, né?! Pra você poder fazer daquele momento um momento único!... Poder aproveitar a resposta do público, poder aproveitar as coisas que só o momento dá, né?!” 
Assim, notamos que existe uma dimensão espontânea no brincar do grupo: "do acaso”, do imprevisível - a improvisação peculiar a cada instante. Contudo, vale destacar que esse aspecto, do improviso, é observado em inúmeras manifestações estéticas populares, musicais (Pais, 2009) e teatrais (Muniz, s.d.). Mas, nas atividades do Seu Estrelo, identificamos também que, apesar do improviso concretizado na relação brincante e público-brincante, existe uma pré-estruturação da roda que abarca a ordem de entrada das figuras. Essa ordem é, por sua vez, discutida coletivamente.

Figura 22 - Discussão da ordem das figuras; e Figura 23 - Detalhe das anotações
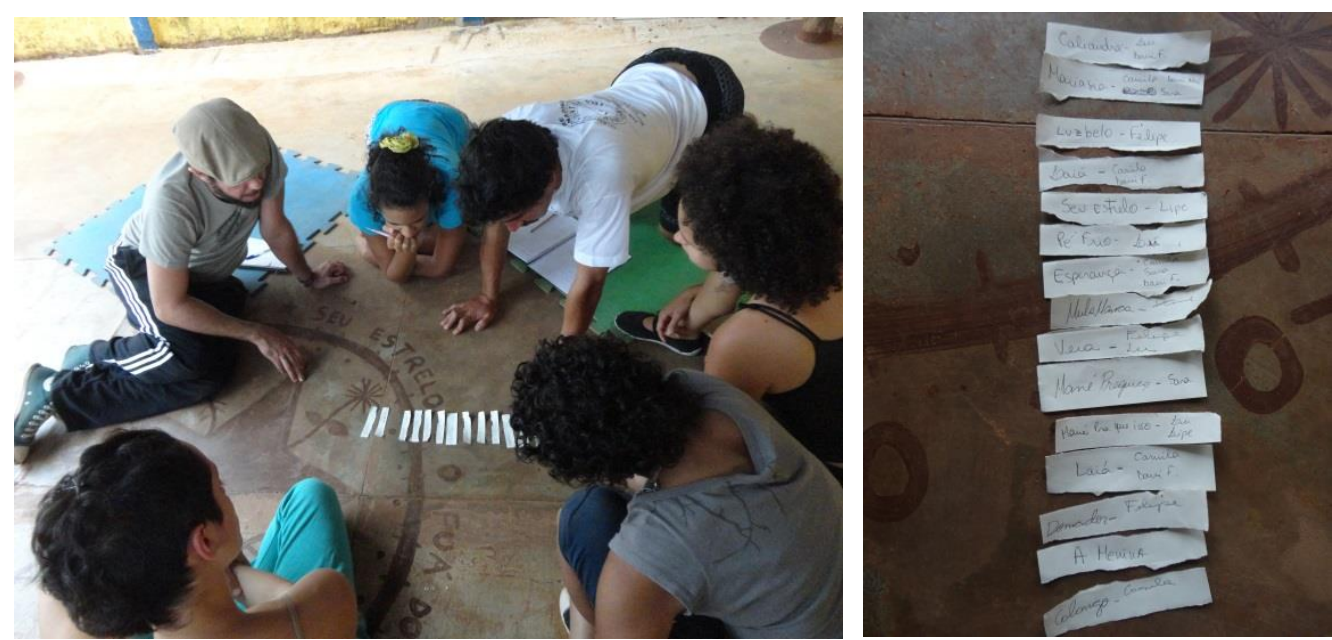

A discussão da ordem de entrada das figuras é realizada a muitas mãos, rabiscos e olhares. Fotos do acervo da pesquisadora - 2013

Nesse jogo cênico do Seu Estrelo, de rodas que são pré-estruturadas e improvisadas, reforçamos que preparar o espaço é fundamental. Conforme nos disse Lipe, esse preparo faz parte de uma tentativa de "trazer o teatro pro terreiro, e levar o terreiro pro teatro". Assim, o teatro de terreiro é também uma espécie de fusão entre territórios, por vezes, alheios ou distantes: o teatro e o terreiro.

Lu, por sua vez, resgata uma vivência com o grupo bastante oportuna para nossa discussão. Nela, a brincante refere-se a uma temporada do Seu Estrelo no espaço Funarte (Fundação Nacional de Arte, do Ministério da Cultura), em Brasília: 
"o Tico trouxe uma reflexão... Porque a gente ficou uns três dias lá [na Funarte] montando, ensaiando, e ele falou assim: 'cara, vamos! Porque é pras figuras poderem se acostumar com esse espaço aqui! Pra elas ficarem à vontade, pra chegar aqui também'. Mas... Assim... Não é sempre que a gente brinca que a figura chega, entendeu?! Eu não sei exatamente o que é que faz uma figura chegar! Eu sinto que tem a ver com como que a gente tá no dia... O tanto que a gente tá realmente aberto... Como que tá a energia do grupo..."

Aqui, é interessante identificar como a brincadeira do grupo vai se constituindo mediante uma complexidade de elementos, que vão além do momento da roda. Nisso, resgatamos novamente as discussões de Bakhtin (2005), que defende as expressões estéticas populares num entrever entre arte e vida, como o carnaval. Claro que, de forma mais ampla, toda expressão estética acontece nessa tensão; a arte em si é uma expressão da vida humana.

Mas identificamos, pelas narrativas de nossos brincantes, uma relação peculiar entre a vida (cotidiana) e a brincadeira (extracotidiana). Nesse ponto, cabe relembrar a declaração de Tico de que ser brincante é um sacro ofício, que ele exerce "o tempo inteiro", e que esse exercer cotidiano é um fundamento para que a figura chegue à roda. Sobre esse aspecto, notamos que fazer-ser brincante no teatro de terreiro, mais do que vestir figura, é olhar o mundo pelos olhos do brinquedo, conforme Lu esclarece:

“...o brincante, ele precisa ter experiência de vida. O que vai te fazer um brincante são as experiências de vida que você vai tendo, a consciência que você vai tendo! Porque o discurso de um brincante, ao contrário de um ator que decora um texto, e não necessariamente ele precisa estar comprometido com aquilo que ele fala... O brincante, ele tem um compromisso com o que ele fala! Porque, de alguma forma, é a opinião dele, é a visão de mundo dele... Que é uma coisa que o Tico fala 
muito, que é assim: 'a brincadeira... O brinquedo tem que ser por onde a gente olha o mundo'”.

Identificamos que Lu evidencia também a dimensão consciente em seu constituir-se brincante. Fazer-ser brincante, nessa via, é desenvolver uma consciência brincante com base nas "experiências de vida que você vai tendo". Tais experiências de vida, para os/as nossos/as brincantes, é o que fortalece a brincadeira e, ainda mais, o que a viabiliza. Tico narra algo importante sobre o assunto quando argumenta que a cultura popular, como comunhão, tem que permeá-lo o tempo inteiro. Ele diz:

“vamos dizer [por exemplo], eu vou botar o Capitão [uma figura]... E quando eu falo essas coisas de cultura popular, quando eu falo assim: 'poxa, a gente precisa comunhar ${ }^{45}$, querer comunhar'.. Isso tem que ser um exercício diário pra que eu bote figura, sabe?! Assim, não é só vir pro ensaio quarta-feira pra botar figura, sabe?! Essa é a diferença um pouco da cultura popular, assim, porque aquilo tem que fazer parte do meu dia, sabe?! [...] Pra quando o Capitão chegar, meu corpo entender isso, eu dar pro Capitão esse sentimento, sabe? [leva a mão ao coração] Então é uma coisa diária! [...] Isso que eu tô te falando, da cultura popular, isso tem que me permear! Porque se não vira técnica... É técnica pura! Então, é mais profundo que isso, sabe?! Nesse botar, você realmente [tem que] se aprofundar pra botar, né?! [...] É o que eu falo muito, tipo: o mito, ele não é um mito pra mim pôr uma história que bota figuras. Mas é porque, no mito, tem referências de coisas que eu levo pra vida, sabe?! Se eu pegar o Seu Estrelo [figura], cara, que é uma figura que é dono de uma mata, que tem toda uma mata e, cara, se entrega! Ele se entrega pra gente! Sabe?! É de uma generosidade absurda isso, o Seu Estrelo, sabe?! Então, isso pra mim é um exemplo de alguém, sabe?! De uma postura! Por isso que, pra mim, isso é um mito! Porque é uma

\footnotetext{
${ }^{45}$ Neologismo derivado do termo comunhão, comunhar é o ato de 'fazer' comunhão, comungar.
} 
história que me fala sobre como eu também tenho que estar no mundo, sabe, assim? Tipo, não é uma história que eu vou ali e pego a figura... É uma história, assim, que ela tem uma fluência, sabe? É massa escutar Laiá [figura], ver a história de Laiá e tentar entender essa fluência, que ela tem, e jogar isso pra mim, sabe?! Uma Esperança [figura]... Sabe?!"

Lu também discorre sobre a importância do exercício diário para a brincadeira. Ela narra: “[...] então, o que eu sinto, é que é um disponibilizar-se... E aí você tem que trabalhar isso no seu cotidiano... O seu corpo.... Essa disposição, essa abertura mesmo, energética! Esse... Estado de graça!... Porque quando você vai pra roda, a figura chega. E eu sinto assim, não é uma incorporação, sacou?! Como em um terreiro, num trabalho espiritual. Eu brinco junto com a figura! Entendeu? A gente brinca junto, eu sinto!...”

Lipe, por sua vez, estabelece tal relação entre vida e arte enfatizando como a figura que ele bota/veste há mais de dez anos, o Seu Estrelo, e a sua história de vida possuem uma forte conexão:

“mas, daí, vendo... E a gente [o grupo] conversando sobre os personagens, as figuras... Aí, eu fui entender que o Seu Estrelo é um caçador, protetor da mata! Ele é o filho da Terra com o Rio, ${ }^{46}$ né?! O filho de Laiá com o Rio, né?! Então, ele [o Seu Estrelo], pela mãe dele ter sido levada pelas águas... Ele se afasta do Rio e vai ficar na mata, né?! [contando a história do mito]. Então, ele é esse protetor da mata virgem! E eu, desde sempre, desde os 15 anos, em que comecei a atazanar minha mãe com rock'n'roll, conheci um pessoal que ia muito pra floresta, lá em Taguatinga! E lá, [a gente] fazia várias brincadeiras de imitar animal, a gente passava a noite na floresta, lá no escuro... Ficava lá ouvindo os bichos, ia muito lá pra tomar banho de rio...

\footnotetext{
${ }^{46}$ Figura que compõe a nova roda do grupo, denominada de "O Amor é Rio sem Margem".
} 
Então, tinha muito essa brincadeira com a floresta, assim, de ficar imitando animal. E o Seu Estrelo é essa figura, né?! Ele é essa figura da mata, que protege a mata, ele foi o criador dos bichos, né?! Com o canto dele é que foram surgindo os bichos... [no mito]. Então, eu tive essa identificação muito forte com o Seu Estrelo! O Seu Estrelo, ele é, na nossa história aqui, do nosso grupo, o único personagem que a gente ainda não... Não, o único não! Tem o Capitão também, né?! Mas são os únicos que a gente não girou [trocou] as pessoas. Porque a proposta do grupo é que os personagens, as figuras, sejam independentes das pessoas... O Seu Estrelo é um que a gente nunca girou! E eu tenho essa identificação forte com o Seu Estrelo!..."

Nas narrativas supracitadas, identificamos, novamente, algumas relações entre as expressões estéticas de nossos/as brincantes e os jogos de faz de conta das crianças. Sobre isso, é válido retomar as contribuições de Silva (2006) e Magiolino (2015), que discutem a experiência de outridade e a dimensão performática nesse tipo de brincar infantil. Segundo as autoras, no faz de conta, a criança vê o outro pelos olhos do papel/personagem que ela representa - vê o outro pelos olhos do bandido, como citamos. Os/as nossos/as brincantes, por sua vez, parecem também ver o outro pelos olhos das figuras, jogando com as características delas: é “jogar isso pra mim, sabe?”, disse Tico. Porém, trata-se de uma experiência de outridade/performática, ao mesmo tempo, bastante distinta dos jogos infantis por, pelo menos, três aspectos: a) os brinquedos populares, de forma mais ampla, constituem-se em um contexto artístico, no qual o brincar sugere outro tipo de exotopia, em que há um excedente-interno de visão, conforme argumentamos; b) o brincar assume uma dimensão profissional, discutida no eixo A; e c) diferente de uma criança, que vê o outro pelos olhos do personagem no momento da brincadeira, nossos/as brincantes parecem ver outro (e o 
mundo) pelo olhar da figura cotidianamente, portanto, para além do momento da brincadeira.

Nessa relação entre figura e si mesmo, os/as brincantes identificam aspectos das figuras que transformam suas vidas, "[...] que me fala[m] sobre como eu também tenho que estar no mundo", conforme narra Tico. Além disso, as suas experiências passadas também constituem as figuras, como observamos na narrativa de Lipe ao relacionar seu vínculo com a floresta com as características da figura denominada Seu Estrelo.

No contexto do teatro de terreiro, percebemos também que ser brincante é brincar "junto com a figura", como aponta Lu. É, portanto, reinventá-la e reinventar-se a partir dela; da própria criação estética. Esse reinventar, de acordo com a brincante, é uma construção que demanda “... disposição. Essa abertura mesmo, energética! Esse... Estado de graça!”

Manter-se, contudo, em um estado de graça, necessário ao fazer-ser brincante, consiste em uma missão complexa e, por vezes, árdua para eles/as. Veremos, a seguir, que, no atual contexto capitalista, tal estado de graça tem sido convertido, na realidade, em um trabalho de graça, desvalorizado pelo sistema. Aqui, vale também resgatarmos a obra do brincante Herbert Lucena (ver capítulo 3), no qual o artista reivindica, no título de seu $\mathrm{CD}$, a valorização da arte popular com o seguinte argumento: "não me peçam jamais que eu dê de graça, tudo aquilo que eu tenho pra vender" (2011, grifo nosso).

Assim, de uma perspectiva do trabalho em estado graça — da magia, do encantamento, dos rituais, das experiências catárticas - , passaremos para as discussões sobre os movimentos de resistência e lutas políticas, profundamente necessários aos/às nossos/as brincantes. Por essa via, notaremos que eles/as se veem desenvolvendo um 
trabalho ainda pouco recompensado (de graça), nas amarras econômicas da venda e do lucro que se estabelecem no chamado mercado artístico/cultural brasileiro.

\subsection{Eixo C) Trabalho e luta: políticas de resistência pelo encantar}

O conceito de cultura popular é historicamente desvinculado do contexto formal/oficial de uma suposta ordem vigente (Chartier, 1995). Para Bakhtin (2005), a cultura popular é anticanônica por natureza. Seu corpo coletivo não comporta o corpo individualista burguês (Bakhtin, 2005), conforme discutimos no capítulo 3.

Já enfatizamos que, para continuar existindo em contextos socioeconômicos amplamente excludentes, meritocráticos e individualistas, as expressões populares assumem um caráter de resistência e de denúncia do sistema (Brandão, 2011; Gullar, 1983). Assim, atualmente, optar pela brincadeira como ofício, apesar de ser um caminho viável — como apontou $\mathrm{Lu}$, no eixo $\mathrm{A}$-, para nossos/as brincantes também é um trajeto árduo, marcado pelas lutas políticas.

Nessa conjuntura, que abarca a dimensão denunciativa da cultura popular, nos chamou a atenção o Mito do Calango Voador ${ }^{47}$ que conta a história das figuras do Seu Estrelo. Nele, parece haver uma alusão ao sistema capitalista, que é denominado de $A$ Grande Coisa ou a Triste Criatura Comedora de Homens:

[...] a Coisa já tinha crescido tanto, que começou a ocupar a Terra Além-Mar. Já tava tão grande que para chegar de um lugar para o outro dentro dela, os homens começaram a construir estradas. Alguns homens, que tinham sido engolidos pela Coisa como escravos, agora, já mandavam nos outros homens. Eram escolhidos pelo criador da Grande Coisa para controlar os

\footnotetext{
${ }^{47}$ Ver anexos, p. 176.
} 
escravos e suas revoltas. Em troca, ganhavam lugar privilegiado dentro da

Criatura. (Mito do Calango Voador: III parte, escrito por Tico, grifos nossos)

Essa Grande Coisa, Comedora de Homens, portanto, faz parte do imaginário do grupo. Dessa forma, ao abordarmos as políticas de resistência na constituição dos/as brincantes, utilizamos expressões como Grande Coisa, A Coisa e Máquina Engolidora de Homens. Assim, no decorrer das entrevistas, indagamos aos/às brincantes, por exemplo: como é ser brincante dentro da Grande Coisa?

Para Lu, decidir ser brincante profissional requer, também, se sustentar financeiramente. Ela narra que, na atual lógica capitalista, inúmeras vezes necessitou transformar o seu trabalho, "a sua energia mais preciosa, de transformação do mundo”, em produto:

ANDRESSA: "Como é isso, Lu? Essa coisa da Grande Coisa?... Da Máquina Engolidora de Homens?"

LU: "Pois é! Então, é isso!... [encolhe o corpo, como se estivesse atrofiada] Isso é que é difícil, sabe?! Conseguir manter esse estado do brincante... Dessa leveza, dessa conexão, dentro da lógica da Grande Coisa! Porque é isso... Ela te transforma em produto, cara! Ela te bota numa lógica de comércio, e aí, de repente, você [se questiona]: 'cara, será que é isso? Será que não é?’ Mas você precisa da grana! [gesticula como se estivesse angustiada]. Aí você faz umas coisas nada a ver [tapa o rosto com as duas mãos, como se tivesse com vergonha]... Aí você fala: 'eu brinco não é pra isso!' Mas aí você precisa da grana e tal... Então, é uma relação conflituosa!"

Sobre tal relação conflituosa, Lu prossegue relatando uma das suas vivências “nada a ver”, como brincante: 
LU: "Porque o brincar... Uma coisa é você brincar quando você tá ali, na energia de brincar... Mas aí, pô... E o dia que você tá doente? O dia que você tá, sei lá... Na TPM? Sabe? [...] E aí você tem que ir lá e brincar! Tem que ir lá e dar o seu melhor pro mundo... Estar naquele estado de encantamento, de graça!... Esse estado extracotidiano. Porque é quase como... [silêncio]. O que eu vejo, assim, de você começar a trabalhar com o brinquedo, é que você tem que trazer esse estado extracotidiano pro seu cotidiano. Tem que começar a estar nesse estado de graça cotidianamente, porque, aí, é isso: 'o que que é trabalhar com a palhaça?' Aí, surge lá... Greve dos bancários! [por exemplo]. Aí, o sindicato contrata a gente pra ir fazer animação da greve! Aí, de segunda a sexta feira, tô eu lá, na porta do banco, e 'pa nam nam' [gesto de 'animação' com os braços], pra ganhar uma grana! Ah! [imita uma outra pessoa falando] 'Vai ter divulgação do evento não sei o quê... Vai lá com a sua palhaça!' Entendeu?! [...] Era difícil estar nesse estado de doação, de graça e tal... Nesse estado do brincante [abre os braços como se estivesse 'de peito aberto'] pra estar lá, na greve dos bancários, colocando o discurso dos bancários na boca da palhaça. Mas porque eu precisava daquela grana! [...]”

ANDRESSA: "Você acha que a palhaça se perdia ali [naquele contexto]?"

LU: "Eu sinto assim [coloca as duas mãos sobre o peito], que eu não chegava a me perder, porque eu sempre dava um jeito de me empoderar do discurso, sabe?! Se é pra falar... [...] Então, beleza! Bora falar, aqui, contra o patrão! Dos banqueiros que exploram a mão de obra barata e não sei o quê... Então, a gente [ela e Thiago, companheiro de palhaçaria] dava um jeito de se ver naquilo... Porque, minimamente, eu tenho que acreditar no que eu tô falando. Porque, se não, eu não consigo! Mas sim, foi muito difícil! De ir entendendo isso... de como lidar com a Grande Coisa, de como lidar com esse universo." 
É interessante perceber como essa experiência da brincante relaciona-se com a noção de espetacularização das culturas populares apontada por Carvalho (2005, 2010). Aqui, um agente externo, no caso, o sindicato dos bancários, contrata a palhaça para animar sua greve, descaracterizando a brincadeira, fato que ela relata ter sido "difícil". Em seguida, Lu argumenta que, apesar da dificuldade em atingir um estado de graça necessário ao brincar, criava uma forma de se "empoderar do discurso" do seu contratante.

Nesse empoderamento, a palhaça fala “contra o patrão! Dos banqueiros que exploram a mão de obra barata”. Aqui, identificamos como a luta de classes se apresenta de uma forma peculiar: a brincante parece se sentir explorada pelo sindicato, que, por sua vez, é explorado pelo patrão, como uma espécie de cadeia; mas, ao mesmo tempo, ela também se empodera do discurso do sindicato e se recoloca dentro desse dramático jogo das relações sociais. Isso se relaciona também com o mito do grupo neste trecho que retomamos: "alguns homens, que tinham sido engolidos pela Coisa como escravos, agora, já mandavam nos outros homens. Eram escolhidos pelo criador da Grande Coisa para controlar os escravos e suas revoltas".

Ainda em alguns desdobramentos interpretativos, relacionamos o trecho do mito e os relatos de Lu com a noção de alienação do trabalho (ver capítulo 1), em que $a$ Coisa é o próprio capital. Já aqueles que contribuem para a sua manutenção, em troca, ganham "lugar privilegiado dentro da Criatura”, isto é, viram patrão. Nesse contexto, notamos que fazer-ser brincante profissional é ter que lidar também com o próprio sistema, que conforme, argumenta Tico, parece ir contra. Ele narra:

TICO: “O sistema, na verdade... é muito, assim... feroz, sabe?! Ontem, a gente conversando... Só pra contextualizar: o maracatu rural, o maracatu de baque virado e o cavalo marinho, hoje, estão ganhando... estão sendo [se tornando] 
Patrimônio Imaterial Brasileiro pelo Iphan [Instituto do Patrimônio Histórico e Artístico Nacional], e ontem, os três mestres, cada um de uma brincadeira dessa, estavam aqui [na sede do grupo]. E aí assusta um pouco a conversa, sabe? Assusta porque você vê a situação em Pernambuco, no Brasil, como a cultura popular é tratada, né?! Assusta muito, na verdade! Porque você fala: 'pô, eu tô lutando por isso, tô brigando por isso também'."

ANDRESSA: "Fala um pouco mais disso, Tico... O que é que mais assusta?"

TICO: “Ah, assusta porque você vê que não tem condições, né?! Assim, o sistema é pra quebrar, né?! O sistema, o governo, as coisas da comunicação, né?! O que é falado no jornal, nas coisas... É pra quebrar! [...] Aí, você não tem profundidade nas relações. E, o tempo todo, é tudo muito tratado como mercadoria, né?! Tudo muito... O sistema veio pesado pra essas culturas, pra essas pessoas!... Cada vez mais burocrático, cada vez, assim, mais cheio... E a impressão que dá é que é intencional, não é uma coisa sem intenção!"

Tico continua, enfatizando como o sistema hegemônico é incompatível com a noção de cultura popular:

“eu acho que a gente [a humanidade] se perdeu muito, assim... Na verdade, eu vejo muito pouca saída pra humanidade! Pelo sistema mesmo! A forma com que a gente construiu o sistema... Assim, que os poderosos [abre os braços], que as pessoas que estavam com esse poder, criaram esse sistema... Eu acho que existe muito pouco caminho pra humanidade, e eu acho que um desses caminhos é a cultura popular. Na verdade, pra mim, o único caminho é a cultura popular... Se a gente entende ela nesse aspecto mais amplo $^{48}$, né?! A cultura popular, ela acaba trabalhando com

\footnotetext{
${ }^{48}$ Entendemos que a cultura popular, "compreendida em um aspecto mais amplo" se relaciona com a produção de sentidos essencial a experiência humana, integrando a noção de comunhão; se contrapondo, assim, a noção individualista do sistema dominante; que tem instaurado a perda de sentido, como discutimos pela obra de Namura (2003). Aqui, longe de querermos reforçar visões
} 
algumas coisas que eu acho que a gente [humanidade] perdeu na história toda... [...]

Ela trabalha com a ideia de comunhão, aí você tem que comunhar! É um processo o tempo todo de comunhão. Então, num mundo cada vez mais individualista, né, cada vez mais voltado pro consumo, cada vez mais nessa coisa de você 'se preenche e se esvazia', né?! O sistema lhe preenche de alguma coisa que você consome e, depois, você tem que se esvaziar, pra estar aberto pra consumir outra coisa! Então, eu acho que as coisas são muito rasas, assim, né?! E muito individualistas, também, você não tem muita troca. E a cultura popular trabalha com essa ideia da comunhão, o tempo todo 'vamos se juntar', 'vamos comunhar', essa coisa do 'não comparamento', você não se comparar. Cada um é um, porque cada um é um milagre dentro do ser, cada um é uma existência... Então, essa força que cada um traz, esse universo particular que cada um é [...]. Isso é massa!... É comunhar, mas dentro do universo de cada um! [...] Então, todo o sistema é contra isso, de você realmente se redescobrir."

Lipe, por sua vez, parece corroborar as ideias de Tico sobre a estrutura "rasa" do sistema. $\mathrm{O}$ brincante narra:

“...eu vejo hoje que, assim, o problema maior é a falta de confiança em si mesmo. Porque as pessoas crescem na cultura do medo, de nunca acreditar na sua própria capacidade... Pra, aí, ter que recorrer, obrigatoriamente, ao serviço público, às ofertas que o mercado te dá! Que, daí, o mercado pode controlar tudo do jeito que ele quiser, né?! [Enuncia como se fosse o mercado falando:] 'Eu vou ofertar tantas vagas disso e eu quero tantas pessoas pra ocupar aquelas vagas!' E as pessoas vão

românticas sobre a cultura popular, que exclui as tensões sociais presentes nesse contexto, entendemos que o brincante introduz uma noção subjetiva do termo (de comunhão), para enfatizar que, nesse aspecto, a cultura popular "é o único caminho", para ele, de encontrar-se consigo mesmo, de não se perder, isto é: para não se perder é preciso "comunhar" com os outros. Isso não significa que estamos defendendo a cultura popular como um caminho único de "comunhão" ou "salvação" para a humanidade, mas que para o brincante, o universo popular o ensinou a "comunhar", fato que ele considera divergir da atual perspectiva "individualista" do sistema capitalista. 
nesse caminho de boi, assim, né?! Sendo aboiadas! [...] Porque, hoje em dia, nessa cultura do medo [...], acaba que a pessoa nunca consegue chegar lá, na essência das coisas! Na profundidade, no cerne dos problemas, do caminho”.

Essa falta de aprofundamento que a Grande Coisa institui, observada nas narrativas de nossos/as brincantes, dialoga com a discussão desenvolvida pela pesquisadora Namura (2003). Para a autora, o sentido ontológico da experiência humana, na lógica capitalista, é substituído pelo fetichismo das mercadorias, que direciona a humanidade para o individualismo. Nesse viés, instaura-se o sentido da insegurança, da fragmentação e da perda do próprio sentido, como discorremos no primeiro capítulo.

Porém, mesmo instaurada A Grande Coisa e, com isso, todo o esvaziamento de sentidos que ela impõe ao "homem", nossos/as brincantes parecem querer resgatar o sentido ontológico da experiência humana, pelo brincar. Mas, de fato, o sistema joga contra, e é preciso se sustentar em meio ao jogo. Conforme analisamos até aqui, esse resgate é conflituoso e, em termos vigotskianos, dramático. Trata-se de um resgate contraditório, com lutas internas que produzem um choque de sistemas decorrente das conflitantes posições sociais que são travadas no interior da pessoa. Vigotski (2000) afirma: “o drama realmente está repleto de luta interna impossível nos sistemas orgânicos: a dinâmica da personalidade é o drama (p. 35)".

Diante das dificuldades, entretanto, é interessante notar como o universo popular busca restaurar noções opostas ao capitalismo, como a de comunhão ( $x$ individualismo), por exemplo. Para Tico, a cultura popular contempla também a historicidade "daqueles que perderam" e que foram silenciados pelo sistema oficial. Ele diz: 
“...uma outra coisa que se corta muito da gente [que o sistema corta], e que eu acho que a cultura popular traz, é que a gente não se reconhece muito na história, né?! Porque quem conta história é quem ganhou, então, quem perdeu não sabe a sua própria história. [...] [A cultura popular traz] essa força, que eu acho que é um pouco isso, assim, é essa comunhão! Esse reconhecer de histórias, de quem sou eu, sabe?! Meus heróis já não são os heróis de... Meus heróis são os que perderam, sabe?! É quem lutou perdendo, assim, sabe? Negros, pessoas comuns que estavam ali e que lutaram pra transformar as coisas, várias [coisas], assim!... Escravas que vendiam doce e que conseguiam a alforria por causa dos doces e que, ali [em sua região], criaram uma comunidade como é o Xambá. ${ }^{49}$ Malunguinho ${ }^{50}$, também, que é outro herói! Assim, várias outras figuras que você nunca ouviu falar e nunca vai ouvir falar no ensino oficial... com essa cultura europeia que, o tempo todo, jogam pra gente, né?! Então... E que, na verdade, é isso que eu falo, assim... Não é nem que seja ruim a cultura europeia, tem coisa boa pra dedéu, também! Mas a gente precisa se entender melhor, quem nós somos... Não receber só uma [cultura], mas entender essa mistura toda do que é essa [nossa cultura]..."

Pela narrativa de Tico, a cultura popular abarca o reconhecimento histórico de trajetórias sociais que não são contempladas pelo sistema de ensino oficial, de forma a promover também um reconhecimento de si mesmo. Assim, identificamos que um dos elementos de resistência da cultura popular é, justamente, essa outra dimensão histórica que ela congrega e que marca, profundamente, a constituição subjetiva dos/as brincantes.

\footnotetext{
${ }^{49}$ Situada em Olinda (PE), a Comunidade Xambá é reconhecida pelo MinC/Iphan como o primeiro Quilombo Urbano de Pernambuco. Ver http://www.palmares.gov.br/?p=1730\&lang=es.

${ }^{50}$ Malunguinho (João Batista, falecido em 1835) foi um militante e guerreiro do quilombo do Catucá. Atualmente, ele é uma entidade afro-ameríndia cultivada em terreiros religiosos de Umbanda eJurema, entre outros.

Ver http://tendasaojorge.blogspot.com.br/2014/06/malunguinho.html e https://pt.wikipedia.org/wiki/Malunguinho.
} 
Nesse "reconhecer de histórias" e de "quem sou eu”, Tico alega que seus heróis são "aqueles que perderam”, pessoas invisibilizadas pela Grande Coisa. O brincante prossegue argumentando que, na realidade, perder ou ganhar é relativo e que, na ordem vigente, ganhar é muitas vezes um ato de violência. Ele narra:

“[...] ganhar, muitas vezes, já é uma violência, seja o que for, já é um ato de violência!... Então, o que significa esse ganhar? O que significa esse perder? Então, a cultura popular, ela traz ainda essa história da gente! Essa verdadeira história da gente! Que não é essa história oficial que a gente aprende e que só distancia a gente da gente mesmo e do mundo."

Lipe, por sua vez, destaca que ainda existe uma ideia equivocada, no Brasil, sobre o que é a cultura popular. Segundo ele:

“muita gente já olha a cultura popular e... Quando fala 'cultura popular', já lembra 'daquele senhorzinho', né?! Que já é velho, que vai cantar aquela música tal... Então, tipo aquela coisa assistencialista, né?! De 'ah, é bonito o senhor fazendo!' Tipo aquela coisa de 'crianças carentes' que a pessoa vê e 'ah, bonito, né?! São crianças carentes, então, é bonito!' Ou é aquela coisa que os figurantes não têm condição, são tudo lascado mesmo, que a pessoa não tem dinheiro, então já tem todo esse... [...] Esse preconceito, esse estigma, essa... Já tem essa imagem formada da cultura popular, né?! De pessoas que não têm condição, pessoas de classe baixa fazendo e, por conta de não ter condição, a coisa acaba saindo meio assim [sinal de 'mais ou menos' com as mãos]... Porque a pessoa não tem condição de ensaiar, de dinheiro pra estar ensaiando, de dinheiro pra fazer o figurino e tal, fica aquela coisa mais ou menos, quase legal né?! Então, quando a gente consegue buscar mesmo esse lugar pra fazer a figura chegar... Quando ela chega, é impacto, né?! Em qualquer um que esteja 
olhando! Então, isso já transforma a pessoa de 'caraca, véi, é cultura popular, né?!' Então, já muda um pouco, né?!”

Pelas considerações de Lipe, é interessante retomarmos as contribuições de Freire (1983) sobre os Movimentos de Cultura Popular da década de 1960, discutidos no capítulo 3. Lembremos que esses movimentos ressignificaram o conceito de cultura popular, que passou a referenciar um contexto de trabalho coletivo que valoriza os saberes/fazeres do povo, opondo-se aos assistencialismos governamentais da época. Mas observamos que, mesmo com as contribuições desses movimentos, ainda hoje existe um olhar "assistencialista" para as expressões populares — um olhar para “crianças carentes”, como Lipe enfatiza.

Além disso, parece-nos que a narrativa em questão relaciona-se também com as noções exóticas e românticas, já discutidas, sobre a cultura popular. Isso porque, na visão exótica, a cultura popular é posta como uma cultura à parte, distante, dos humildes (Chartier, 1995) — “a classe baixa” ou aquela coisa do passado, daquele "senhorzinho que vai cantar aquela [mesma] música", como relata o brincante.

Já a visão romântica concebe a cultura popular como uma cultura simples, que carece de complexidade (Arantes, 2006), algo também primitivo, “mas bonito” ou “quase legal” — aquilo que é modesto ou até mesmo ingênuo, coisa de "crianças". Na realidade, ambas as visões comportam concepções depreciativas da cultura popular, que são camufladas pelo romance e pelo exotismo embutido.

Assim, quando Lipe diz que o Seu Estrelo impacta "qualquer um que esteja olhando" a figura chegar na roda, e que, a partir desse impacto, as pessoas transformam suas concepções — por vezes, românticas e exóticas — da cultura popular, acreditamos que isso também faz parte das políticas de resistência do grupo e das expressões 
populares de forma mais ampla. Essa não é uma resistência de "isolar-se" em uma comunidade, como afirma Tico, mas uma resistência que "fura" a Grande Coisa:

“...porque a parada [a Coisa] tá o tempo todo te engolindo e você vê que tá engolindo, e aí você fala: 'massa, então, o que é que eu posso usar dessas armas? De repente, sem a galera perceber!' Mas percebendo também... Furando ali... De repente um que tá lá dentro [da Coisa] tá percebendo também e ajudando no processo! É você ir furando, de alguma forma, esse negócio, né?! Então, o trabalho também vem nesse sentido, né?! É isso que eu falo, não é uma brincadeira que você acha e fala 'pô, massa! Então é isso, e agora vamos aqui criar uma comunidade e se isolar'. Não! Mas assim, sabe: como é que a gente entra nisso [no sistema]? Como é que a gente fura isso? Como é que a gente entra nesses lugares?..."

Nessa via, resistir é "não passar a vida entregue ao sistema", mas buscar transformá-lo. Para isso, Tico diz ser necessário entender “suas armas”, já que também se trata de uma "guerra". Ele continua:

“...você vai partir pra uma guerra! Assim, não tem um sentido do 'se isolar', sabe?! [...] A relação é tipo assim... Pra mim, é um pouco dessa transformação [do sistema], sabe?! [...] E aí, dentro disso [dessa transformação], eu preciso estar no mundo! Assim, eu preciso entender ele e preciso sacar essas armas dele um pouquinho pra que eu também possa pegar essas armas e brigar com ele, sabe?! Então... Sabe... Como é que eu entro nessa estrutura, sem me perder nela? Como é que eu posso entrar nela sem me perder?..."

Não se perder, contudo, é uma missão bastante conflituosa e dramática como vimos nas narrativas de Lu, sobre suas atuações "nada a ver" com a palhaça, devido à necessidade “da grana”. Porém, também percebemos que algumas atuações 
de nossos/as brincantes, aparentemente fora da essência da brincadeira ou do "estado de graça”, são necessárias às situações de guerra impostas pela Grande Coisa.

Por esse percurso, é interessante destacar uma atividade que Tico desenvolveu com professores/as que, segundo ele, comportavam noções equivocadas sobre a cultura popular:

“...a gente fez um encontro de educação, e fazendo uma palestra, pra professor, e tal... É engraçado, porque parece que a ideia de cultura popular é sempre uma coisa mais exótica e diferente, assim... Porque a gente chega sempre todo colorido, pintado... E aí, eu perguntando pra eles: 'mas onde é que tá a diferença? A gente é isso! A gente brinca! A gente é um povo que tem em sua pele e sua alma isso!' Então, assim, isso não é uma coisa fora do que a gente é! Isso é a gente! O que é fora é exatamente essa coisa do individual, do que é esse sistema, isso é que é fora! O que a gente tá fazendo... Essa coisa de se juntar com o outro, de comemorar, isso é o que a gente é!"

Aqui, notamos como Tico busca desconstruir o discurso hegemônico dos/as professores/as sobre a cultura popular, de modo a contribuir para a transformação do sistema, acreditamos. Lu também destaca um trabalho de oficineira que desenvolveu em parceria com uma universidade. Ela narra:

"sempre teve muito desses recursos das oficinas. Eu trabalhei quase quatro anos na Universidade Católica, dando oficinas pros universitários, o que era uma superfonte de recursos e era um trabalho massa, porque a gente tava levando a cultura popular pra universidade! Então eu, que tinha saído da universidade, estava, agora, dentro da universidade. Só que levando a cultura popular!” 
Lipe, por sua vez, argumenta que pertencer ao Seu Estrelo o tornou, em dada medida, um ser mais forte e menos dependente do sistema, mesmo diante das dificuldades enfrentadas cotidianamente para se sustentar. Ele diz:

“...você fica... fica mais forte, por assim dizer... Porque aí, como você mesmo precisa tomar atitude, tomar a iniciativa de fazer as coisas, você depende menos do sistema! Porque aí você pode... Você mesmo é capaz de divulgar o seu trabalho, de elaborar a sua pesquisa, de se apresentar, de construir os seus próprios materiais, construir o seu próprio emprego, né?! Você se sente capaz! Você pode fazer isso, você faz! Você se realiza, você se livra de várias doenças, né?!"

Apesar dessa aparente menor dependência do sistema, reforçamos que os/as brincantes não são alheios a ele, isto é, não vivem em um universo próprio e isolado do mundo. Conforme as narrativas evidenciam, eles jogam com a Grande Coisa e, de certa forma, até a incorporam. Contudo, a incorporação ocorre na perspectiva da resistência — do "não se entregar" a ela. Sobre isso, Tico diz que a cultura popular faz as pessoas enxergarem o mundo de outra forma e essa transformação já é também um processo de resistência:

“...eu acho que é essa história da cultura popular, que te dá uma postura em relação ao mundo, mesmo. E aí você acaba já, por isso, resistindo, de alguma forma! Assim, já é um processo de resistência, porque você passa a enxergar ele [o mundo/o sistema] de um outro jeito... E a não querer se entregar ao que ele é, assim, na verdade!... E aí você começa a brigar, a querer mudar as coisas".

A partir dessa transformação subjetiva, do "enxergar das coisas”, o brincante prossegue narrando que fazer-ser brincante é "encarar a vida" sendo "quem a gente $e^{\prime \prime}:$ 
“...o ser brincante pra mim é ser quem a gente é, sabe?! Não é uma coisa que tá fora, sabe?! O brincante é ver... É encarar a vida assim, é ver o mundo assim, sabe?! E aí o tempo todo ser assim! Isso não muda! Assim, não muda de ir pra uma reunião na Secretaria e 'blá blá blá', continuo sendo ali [brincante]... Desafiando a galera e propondo as coisas e tal. Sei lá... A gente, num festival, a gente já chamou um secretário de Cultura pra dar a chave na boca do Calango... a chave da cidade! $E$ o secretário foi lá e deu a chave da cidade na boca do Calango, entendeu? Como trazer essas relações, dessas coisas... Porque tudo isso [da Grande Coisa] é imposto, né?! Tudo isso também é um imaginário que foi criado, né?! Ter um cara, um governador, um não sei o quê... Essas são relações desse imaginário que foi criado e que é essa a realidade, assim... Como outros imaginários também são! Então, é voche enfrentar isso nesse sentido, sabe?! Então, pra mim, naquele momento, quem estava governando a cidade não era mais o governador, não é o secretário, sabe?! Era o Seu Estrelo e o Calango!"

Assim, o caráter de resistência da atuação política de nossos/as brincantes está em, justamente, permanecer brincante ou ser quem a gente é, porque somos brincantes. Como narra Tico, "a gente brinca" e "comemora", e isso não "está fora da gente, isso é a gente! O que é fora é exatamente essa coisa do individual, do que é esse sistema, isso é que é fora!"

Aqui, vale resgatar nosso argumento de que brincar é uma necessidade ontológica, que abarca todas as etapas da vida humana. Contudo, fazer-ser brincante parece não contribuir para o lucro/capital que move o sistema capitalista, pois não gera fetiches mercadológicos - essenciais a sua estrutura individualista (Namura, 2003) e "rasa" do "ter". Dessa forma, brincar se torna incompatível com a seriedade nociva necessária à sua manutenção, como discutimos no terceiro capítulo. Assim, o sistema 
desumaniza, ou os próprios "homens", inventores da Grande Coisa, se desumanizam por ela; tornando-se exóticos a si mesmos quando deixam de brincar. Por isso, percebemos que fazer-ser brincante ou ser quem a gente é já é um ato de resistência política.

Notamos ainda que essa resistência, nas brincadeiras populares, envolve uma característica peculiar, uma espécie de encantamento. Sobre isso, Tico narra:

TICO: "Eu acho que [a cultura popular] é essa força do encantar, né?! Que eu acho que é muito doida de entender... que é um devolver pelo encantamento! Eu acho que [é] isso, e é [algo] muito generoso na cultura popular.",

ANDRESSA: "Devolver para o sistema, você fala? Devolver pelo encantamento?"

TICO: “É! É você querer quebrar o sistema, mas pelo encantamento, sabe?! Eu acho que isso também é um outro ensinamento de cultura popular, sabe?! Uma fúria criativa absurda, assim... Porque é uma opressão o tempo todo e, na hora de devolver, não é sendo opressor, né?! Você é o tempo todo oprimido, mas na hora que você vai devolver, você não quer ser o opressor, assim... Você parte para um encantamento!... Você brinca com o opressor, na verdade. O opressor, ele também é parte da brincadeira, sabe?! Se tem um olhar também do oprimido pro opressor, sabe?! Ah, você devolve encantando, né?! É um devolver pelo encantamento, mas é um devolver, é uma guerra, né?! Vai guerrear, na verdade!”

Para Tico, apesar de toda a opressão vivenciada, a "guerra" para manter o brincar vivo se dá pelo encantamento: “o opressor, ele também é parte da brincadeira”. Dessa forma, brinca-se com o opressor, não o oprimindo, mas o encantando. Ele continua: 
"engraçado, porque tem essa coisa, da Grande Coisa, que vem engolindo, mas que, no fundo, é uma criatura também! E que tem todo um sentimento, também, sabe?! Que tem toda uma coisa [abre os braços], a Criatura! [...] Eu acho que ela vem oprimindo, assim, a gente, mas eu tenho pena de quem é esse opressor. Eu tenho pena desses opressores também, sabe?! São tão perdidos quanto... É aquela 'pouca coisa do se achar' [maior]!... Então, é uma pena de quem faz isso, quem tá nesse poder, sabe?! É uma pena por ser, nesse sentido, um perdedor já pra mim, sabe?! E como é que eu luto com essa figura?! Assim... É mais buscando encantar essa figura, sabe?! Não é querer tomar o poder, pra ser o opressor, sabe?!”

Logo, o Seu Estrelo vai abrindo seus caminhos de resistência encantando a Grande Coisa: seja em uma roda, convidando o "secretário de Cultura pra dar a chave da cidade na boca do Calango" - e invertendo, naquele instante da brincadeira, a lógica de governo da Grande Coisa —, seja em uma chamada de um famoso telejornal brasileiro, onde "sai uma matéria de três minutos" sobre o grupo - e isso reverbera socialmente, fazendo com que outras pessoas fiquem interessadas no trabalho dele, por exemplo.

Assim, ressaltamos que nossos/as brincantes resistem perfurando o sistema pela lógica do encantamento, afinal, como diz Lu, "brincante é um estado de graça, de encantamento". Mas é também um "sentir-se mais forte”, como Lipe narra. Força que, por sua vez, vem de um "reconhecer de histórias, de quem sou eu", como defende Tico. Por isso, não é um encantamento entorpecedor, que paralisa ou que "isola" os/as brincantes da Grande Coisa, como enfatizou Tico, é um "guerrear encantando”.

Conforme salientamos no capítulo 3, para fazer valer a sua brincadeira, o capitão de uma congada, Antônio Santos, diz: "a minha brincadeira tem que abrir a brincadeira do outro". Assim, acreditamos que fazer-ser brincante é exercitar convites 
de abertura - em que um ser se abre pelo e ao outro, como uma rede que conecta as nossas tradições e as recria no instante estético do encantar, do extraordinário, do milagre da arte que transforma a água em vinho, como vimos em Vigotski (2010).

Fazer-se brincante é assumir, contudo, o milagre que somos — sujeitos que criam, em comunhão, o próprio milagre: a arte. Assim, concluímos com Tico: “o brincante, pra mim, é ser quem a gente é! [...] É você pensar, independente do que você acredita, de religião ou não, do milagre que a gente é, né?! A Verinha Catalão ${ }^{51}$ falou uma coisa muito louca, assim: 'que, se você pensar que você tá num lugar no universo, num planeta, né, que se a gente tivesse um pouquinho mais pra cá, [gesticula um Sistema Solar com as mãos], a gente tava perto do Sol, né?! E, aí, tudo era deserto! E se ele [o planeta] tivesse um pouquinho mais pra trás, era tudo gelo, aí, nada existia porque era tudo muito gelado!' Mas a gente tá em um lugar, dentro de todo o universo, que permite com que fluam as coisas, né? Com que a água exista e, aí, tudo flua, sabe?! E cara, você se dá conta disso? Do que é isso? Do mundo? Da magia que é isso? E você tá vivendo isso, tá no mundo e não assume toda a magia que é isso, sabe, assim?! Tudo que significa ser isso, tá aqui, nesse momento, e o que significa ser isso! Então, eu acho que o ser brincante é assumir essa magia, sabe?! Não tá fora, nem dentro, é você assumir toda essa magia que você é! A beleza que você carrega, sabe?! Assim, não é uma questão de bem ou de mal, não é! Mas ser o que você é! Ser brincante pra mim é... A partir desse momento, desse olhar, você muda o olhar pra vida! E aí, na hora de brincar, quando você tá com uma figura e tá brincando, você acaba devolvendo isso pro momento e é um processo de encantamento..."

\footnotetext{
${ }^{51}$ Professora da Faculdade de Educação da UnB que desenvolve pesquisas sobre a água como matriz pedagógica.
} 


\section{REFLEXÕES FINAIS}

Contrariando tendências epistemológicas dicotômicas (idealista e mecanicista), Vigotski e colaboradores instauraram uma nova corrente psicológica à luz do materialismo histórico e dialético - que enfatiza a dimensão social do "homem" e as condições concretas de formação do psiquismo. Com base nessa vertente, discorremos que a categoria sentido é relevante e vai além dos estudos sobre linguagem, adentrando na dimensão ontológica, que dá ênfase às experiências/emoções estéticas (Namura, 2012; s/d). Conforme afirma Magiolino (2011), "as emoções estão [...] no âmago de tudo que tem sentido, de tudo o que significa" (p. 36).

Buscamos, então, contribuir para uma reflexão sobre os princípios ontológicos que demarcam a experiência cultural do "homem", com especial relevância à sua dimensão estética e artística. Como uma atividade viabilizada pela imaginação, a arte é uma necessidade do psiquismo que transforma radicalmente as emoções (Vigotski, 1999; 2009a), os sentidos e a conduta (Namura, 2102).

Conforme analisamos, para o autor bielorrusso, as emoções estéticas não são tomadas de maneira isolada, mas em "[...] conexão com sistemas psicológicos mais complexos" (Vigotski, 2009b, p. 21). Por isso, a "arte é uma técnica social das emoções" em que, pela vida social, incorporamos "os aspectos mais íntimos e pessoais do nosso ser" (Vigotski, 1999, p. 315). Contudo, ela é também uma forma de comunicação ideológica, que parte da dinâmica dos confrontos e interesses sociopolíticos, refletindo e refratando as lutas de classes (Bakhtin, 2006). A inserção social da arte é, então, marcada por sistemas de institucionalização, que delimitam aquilo que ela é e não é (Bulhões, 1991; 2005).

Nessa tensão, inúmeras manifestações artísticas são deixadas à margem ou são desclassificadas como arte pelo sistema hegemônico. Vimos que grande parte das expressões 
estéticas populares, historicamente, instauram-se nesse lugar desprivilegiado - conceituadas por visões que camuflam os mecanismos excludentes do capitalismo, o exotismo e o romantismo (Brandão, 2001; Fernandes, 1989). Segundo Bakhtin (2005), no século XIX, o pré-romantismo e o romantismo marcaram o desvirtuamento da estética grotesca, a qual a cultura popular era (e, a nosso ver, continua sendo) porta-voz. Para o autor russo, o corpo coletivo dessa estética é anticanônico por natureza e, portanto, incompatível com a lógica individualista do corpo burguês, ainda vigorante, como debatemos.

No Brasil, inúmeras das expressões estéticas populares resistem, contrariando e jogando com a lógica burguesa, pelos/as seus/as diversos artistas - por vezes, anônimos -, entre os/as quais encontramos os/as brincantes. Nessa perspectiva, investigamos o brincar - tema amplamente estudado na psicologia do desenvolvimento infantil - como uma atividade do mundo adulto.

Com base no recente documentário Tarja Branca: A Revolução que Faltava, dirigido por Rhoden (2014), alertamos que a falta de brincadeira tem contribuído para o adoecimento do "homem" contemporâneo. Como relata a professora Pereira, no filme: "deixar de brincar é se violentar". Nessa via, defendemos a necessidade de brincar durante todas as etapas da vida.

Mas, historicamente, vimos que o brincar vem sendo vinculado ao ócio e às atividades não sérias e infantis, que não se relacionam com o mundo do trabalho adulto (Rhoden, 2014). Assim, o brincar nessa fase é desvalorizado, pois não contribui para a manutenção da ordem vigente, isto é, não comporta a seriedade nociva necessária a tal ordem.

Entretanto, por se tratar de uma necessidade ontológica, acreditamos que o brincar vigora, na fase adulta (e nas demais fases), apesar do sistema "jogar contra", como evidenciou Tico, um dos brincantes entrevistados. Assim, nesta pesquisa, em que investigamos a produção de sentidos na/da constituição dos/as brincantes, o brincar apresentou dimensões singulares que dialogam com as brincadeiras infantis de forma contraditória e dramática -, como: a) os brinquedos populares constituem-se em um contexto artístico, no qual o brincar sugere outro tipo de exotopia; e b) o brincar assume uma dimensão profissional (é um ofício).

Destacamos também, na discussão dos dados, o caráter fundamental de resistência das 
brincadeiras populares. Assim, brincar é "guerrear" por uma lógica do encantamento, que possui um caráter político. Nessa batalha, nossos/as entrevistados/as alegaram que ser brincante é uma "condição" e "construção", um fazer-ser que se dá mediante o "fortalecimento" e a "cura" de si próprio. É também o reconhecimento de uma história não oficial do país, que viabiliza um olhar mais profundo para as suas histórias de vida - constituídas na relação, ou em comunhão, com os outros (família, comunidade etc.).

Sobre as possíveis lacunas ou aprofundamentos necessários à temática investigada, um dos aspectos que nos pareceu merecer atenção diz respeito à relação entre brincante e públicobrincante. Isso porque, nesta pesquisa, sugerimos existir outro tipo de experiência e acabamento estético, específico às expressões populares. Conforme apontamos, para Vigotski (2009b) as experiências do ator “[...] vão além dos limites de sua personalidade e compõem uma parte do diálogo entre o ator e o público" (p. 16). Mas, aqui, a experiência do/a brincante parece ser diferenciada (não melhor ou pior), em alguns aspectos, devido a essa relação entre brincante e público-brincante, indicando, assim, futuros desdobramentos de pesquisa que investiguem mais a fundo as nossas sugestões.

Ademais, entendemos que este trabalho sinalizou formas mais sensíveis de se conceber o brincar pelas expressões estéticas populares, realocando esse conceito em 'novos' quadros. Acreditamos que isso possa contribuir para reflexões mais profundas, por vezes até utópicas (mas não idealistas), fundamentais à transformação das condições concretas de vida e de desenvolvimento humano na contemporaneidade.

Assim, desejamos contribuir para recriações do nosso projeto de sociedade, por uma lógica humanizada que considera o sentido ontológico do brincar. Enfatizamos, então, que fazer-ser humano é também fazer-ser brincante, no sentido mais amplo do termo, que vai além dos/as brincantes e da própria cultura popular.

Por fim, citamos uma chamada (música) do grupo Seu Estrelo e o Fuá do Terreiro que traz a figura da Esperança - agora não apenas para a brincadeira do grupo, mas também para a academia. Almejamos que ela seja sempre uma Esperança mobilizadora e, jamais, paralisadora; uma Esperança com letra maiúscula, corajosa, que recupera e nos mostra o/a brincante que 
somos, o milagre que somos! Porque a cada brincante que se faz e se refaz, uma nova roda de Esperança se abre:

A Esperança anuncia a chegada, se despede o meu desespero.

Com a água nos zóios lava a alma, a Esperança chegou no terreiro.

Se despede o meu desespero, a Esperança chegou no terreiro! 


\section{REFERÊNCIAS}

Abreu, M. (2003). Cultura popular, um conceito e várias histórias. In M. Abreu \& R. Soihet. Ensino de história, conceitos, temáticas e metodologias (pp. 83-102). Rio de Janeiro: Casa da Palavra.

American Psychological Association (2010). Publication manual of the American Psychological Association (6 $6^{\mathrm{a}}$ ed). Washington: APA.

Amorim, M. (2009). Memória do objeto: uma transposição bakhtiniana e algumas questões para a educação. Revista de Estudos do Discurso, 1(1), 8-22.

Amorim (2004). O pesquisador e seu outro: Bakhtin nas ciências humanas. São Paulo: Musa Editora.

Arantes, A. (2006). O que é cultura popular. São Paulo: Editora Brasiliense.

Bakhtin, M. (1997). Estética da criação verbal. São Paulo: Martins Fontes (Coleção Ensino Superior).

Bakhtin, M. (2006). Marxismo e filosofia da linguagem (12a ed). São Paulo: HUCITEC.

Bakhtin, M. (2008). A Cultura Popular na Idade Média e no Renascimento: o contexto de François Rabelais. Brasília: Editora Universidade de Brasília.

Barbosa, M. (2011). Sujeito, linguagem e emoção a partir do diálogo entre e com Bakhtin e Vigotski. In A. L. Smolka \& A. L. Nogueira (orgs). Emoção, memória, imaginação: a constituição do desenvolvimento humano na história e na cultura. (pp.11-34). São Paulo: Mercado das Letras.

Barros, E.; Camargo, R. \& Rosa, M. (2011). Vigotski e o teatro: descobertas, relações e revelações. Psicologia em Estudo, 16(2), 229-240.

Bayer, R. (1978). História da Estética. Lisboa: Estampa.

Benjamin, W. (1994). Magia e técnica, arte e política: Ensaios sobre literatura e história da cultura. São Paulo: Brasiliense.

Brandão, C. (2009). Vocação de criar: anotações sobre a cultura e as culturas populares. Cadernos de Pesquisa, 39(138), 715-746.

Brasil (2010). Plano setorial para as culturas populares. Ministério da Cultura (MinC).

Bulhões, M. A. (1991). Considerações sobre o sistema das artes plásticas. Revista Porto Alegre, 2(3), 26-34.

Bulhões, M. A. (2005). Sistemas de ilusão: institucionalizações que não se evidenciam. In A. Martins, E. Costa, R. MONTEIRO (orgs). Cultura visual e desafios da pesquisa em artes. Goiânia: ANPAP.

Bourriaud, N. (2009). Estética relacional. São Paulo: Martins Fontes. 
Carvalho, J. J. (2005). Espetacularização e canibalização das culturas populares. In Ministério da Cultura. I Encontro Sul-Americano das Culturas Populares e II Seminário Nacional de Políticas Públicas para as Culturas Populares (pp. 79101). São Paulo: Instituto Polis.

Carvalho, J. J. (2010). Espetacularização e canibalização das culturas populares na América Latina. Revista Anthropológicas, 21(1), 39 - 76.

Chartier, R. (1995). Cultura popular: revisitando um conceito historiográfico. Estudos Históricos, 8 (16), $179-192$.

Cole, J. (2008). O que é arte. São Paulo: Brasiliense.

Cole, M. \& Scribner, S. (2007). Introdução. In L. S. Vigotski. A formação social da mente. (pp.12-28). São Paulo: Martins Fontes.

Cruz, M. N. (2011). Imaginação, linguagem e elaboração de conhecimento na perspectiva da psicologia histórico-cultural de Vigotski. In A. L. Smolka \& A. L. Nogueira (orgs). Emoção, memória, imaginação: a constituição do desenvolvimento humano na história e na cultura. (pp.85-104). São Paulo: Mercado das Letras.

Cruz, M. N. (2015). O brincar na educação infantil e o desenvolvimento cultural da criança. In D. N. Silva \& F. S. Abreu (orgs). Vamos brincar de quê? Cuidado e educação no desenvolvimento infantil (pp. 67-90). São Paulo: Summus.

Delari Junior, A. (2011). Sentidos do "drama" na perspectiva de Vigotski: um diálogo no limiar entre arte e psicologia. Psicologia em Estudo, 16(2), 181-196.

Fávero, M. H. (2005). Psicologia e conhecimento: subsídios da psicologia do desenvolvimento para a análise de ensinar e aprender. Brasília: Editora Universidade de Brasília.

Feracine, L. Karl Marx ou a sociologia do marxismo. São Paulo: Editora Escala (Coleção Pensamento \& Vida, vol. 8).

Fernandes, F. (1989). O folclore em questão (2a ed.). São Paulo: Editora Hucitec.

Ferrari, M.; Robinson, D. \& Yasnitsky, A. (2010). Wundt, Vygotsky and Bandura: a cultural historical science of consciousness in three acts. History of the Human Sciences, 23(3), 95-118.

Fischer, E. (1987). A necessidade da arte (9ª ed). Rio de Janeiro: LTC.

Fontana, R. (2000). A constituição social da subjetividade: notas sobre a Central do Brasil. Educação \& Sociedade, 21(71), 221-234.

Fontana, R. \& Cruz, N. (1997). A abordagem histórico-cultural. In R. Fontana \& N. Cruz. Psicologia e trabalho pedagógico (pp. 57-66). São Paulo: Atual. 
Freitas, M. T. (2007). Bakhtin e a psicologia. In C. Faraco, C. Tezza \& G. Castro Abreu (orgs). Diálogos com Bakhtin (141-160). Curitiba: Editora UFPR.

Freire, P. (1996). Pedagogia da autonomia: saberes necessários à prática educativa (39 ed). São Paulo: Paz e Terra.

Freire, P. (1983). Conscientização e alfabetização: uma nova visão do processo ( $2^{\mathrm{a}}$ ed). In O. Fávero (org). Cultura popular e educação popular: memória dos anos 60 (pp. 99-126). Rio de Janeiro: Editora Graal.

Gill, R. (2002). Análise de discurso. In M. Bauer \& G. Gaskell. Pesquisa Qualitativa com texto, imagem e som: Um manual prático (pp. 244 -270). Rio de Janeiro: Vozes.

Gomes, C. (2007). O ritual e o lúdico nas tradições culturais: poéticas e performances. In Bião, A. (Ed). Anais do V Colóquio Internacional de Etnocenologia (pp. 6167). Salvador.

Gullar, F. (1983). Cultura Popular (2 $2^{\mathrm{a}}$ ed). In O. Fávero (org). Cultura popular e educação popular: memória dos anos 60 (pp. 49-55). Rio de Janeiro: Editora Graal.

Hildebrand-Nilshon, M., Motzkau, J. \& Papadopoulos, D. (2001) Reintegrating sense into subjectification. In J. R. Morss, N. Stephenson, H. van Rappard (eds.), Theoretical issues in psychology (pp. 289-300). Boston: Kluwer Academic Publishers

Holanda, A. (2004). Mini Aurélio: o dicionário da língua portuguesa (6 $6^{\mathrm{a}}$ ed).Positivo: Curitiba.

Jovchelovitch, S.\& Bauer, M. (2002). Entrevista narrativa. In M. Bauer \& G. Gaskell. Pesquisa Qualitativa com texto, imagem e som: Um manual prático (pp. 90-113). Rio de Janeiro: Vozes.

Laraia, R. (2006). Cultura: um conceito antropológico (19ª ed). Rio de Janeiro: Jorge Zahar Editor.

Lewinsohn, A. (2007) Imprevisto na rua: A figura do mateus na brincadeira do cavalo marinho. In Bião, A (Ed). Anais do V Colóquio Internacional de Etnocenologia (pp. 21-29). Salvador.

Lewinsohn, A. (2008). O ator brincante: no contexto do teatro de rua e do cavalo marinho (Dissertação). Campinas: UNICAMP.

Leontiev, A. (s.d.). O homem e a cultura. In A. Leontiev. $O$ desenvolvimento do psiquismo (pp. 261-282). São Paulo: Editora Moraes.

Lucena, H. (2011). Não me peçam jamais que eu dê de graça tudo aquilo que eu tenho pra vender (Mídia, CD). Produzido por Sony DADC Brasil. Manaus. 
Luria, A. (1991). A atividade consciente do homem e suas raízes histórico-sociais (vol. I). In A. Luria. Curso de psicologia geral (pp. 71-84). Civilização Brasileira: Rio de Janeiro.

Magiolino, L. (2011). As emoções humanas nas experiências vividas: transformação e significação nas relações (est)éticas. In A. L. Smolka \& A. L. Nogueira (orgs). Emoção, memória, imaginação: a constituição do desenvolvimento humano na história e na cultura. (pp. 35-56). São Paulo: Mercado das Letras.

Magiolino, L. (2015). Afetividade, imaginação e dramatização na escola: apontamentos para uma educação (est)ética. In D. N. Silva \& F. S. Abreu (orgs). Vamos brincar de quê? Cuidado e educação no desenvolvimento infantil (pp.133-154). São Paulo: Summus.

Marx, K. (2011). Textos selecionados. In L. Feracine. Karl Marx ou a sociologia do marxismo (pp.99-172). São Paulo: Editora Escala (Coleção Pensamento \& Vida, vol. 8).

Muniz, M (s.d.) A relação ator-público na improvisação como espetáculo. IV Reunião Científica de Pesquisa e Pós-Graduação em Artes Cênicas. Disponível em: $<$ http://www.portalabrace.org/ivreuniao/GTs/Territorios/A\%20relacao\%20atorpublico\%20na\%20improvisacao\%20como\%20espetaculo.pdf> Acessado em: maio de 2015.

Namura, M. R. (2003). O sentido do sentido em Vygotsky: uma aproximação com a estética e a ontologia do ser social em Lukács (Tese). São Paulo: PUC.

Namura, M. R. (s.d.). O aporte da estética na categoria sentido no pensamento de Vygotsky. Disponível em:

〈http://www.ip.usp.br/laboratorios/lapa/versaoportugues/2c15a.pdf>

Acessado em: abril de 2015.

Oliveira, A. M. (1995). O brincar e o desenvolvimento infantil. Perspectiva, 1(22), 129137.

Oliveira, M. C. (2012). Narrativas e desenvolvimento da identidade profissional de professores. Cedes, 32(88), 369-378.

Pais, J. (2009). Artes de musicar e de improvisar na cultura popular. Cadernos de Pesquisa, 39(138), 747-773.

Pedroza, R. L. (2005). Aprendizagem e subjetividade: uma construção a partir do brincar. Revista do Departamento de Psicologia - UFF, 17(2), 61-76.

Piaget, J. (1962). Play, dreams and imitation in childhood. New York: The Norton Library.

Pino, A. (2005). As marcas do humano: Às origens da constituição cultural da criança na perspectiva de Lev S. Vigotki. São Paulo: 2005.

Reale, G. \& Antiseri, D. (2005). História da filosofia 5: do romantismo ao empiriocriticismo. São Paulo: Paulus. 
Rhoden, C. (2014). Tarja branca: a revolução que faltava (Documentário). Produção Maria Farinha Filmes.

Silva, D. (2006). Imaginação, criança e escola: processos criativos na sala de aula. (Tese). Campinas: UNICAMP.

Silva, D., Castro-Tejerina, J., \& Barbarato, S. (2010) La Imaginación Creadora: Aspectos histórico-genealógicos para la reconsideración de una psicologia de la actividad y la mediación estética. Estudios de Psicología. 31, 253-277.

Silva, D., Costa, M., \& Abreu, F. (2015). Imaginação no faz de conta: o corpo que brinca. In D. Silva \& F. Abreu (orgs). Vamos brincar de quê? Cuidado $e$ educação no desenvolvimento infantil (pp.111-132). São Paulo: Summus.

Smolka, A. L. (2009). A atividade criadora do homem: A trama e o drama (Introdução). In L. S. Vigotski. Imaginação e criação na infância (pp. 7- 10). São Paulo: Ática.

Smolka. A. L. (2000). A memória em questão: uma perspectiva histórico-cultural. Educação \& Sociedade, 21(71), 166-193.

Suassuna, A. (1979). A farsa da boa preguiça (2 $2^{\text {a }}$ ed). Rio de Janeiro: José Olympio.

Suassuna, A. (2005). Iniciação à estética. Rio de Janeiro: José Olympio.

Veloso, J. G. (2010). O mestre morreu. Viva o novo mestre. Anais do VI Colóquio de pesquisa e pós-graduação em artes cênicas (pp. 1-4). São Paulo.

Veloso, J. G. (2011). O boi e a máscara: imag-inário, contemporaneidade e espetacularidade nas brincadeiras de boi de São Caetano de Odivelas. Repertório, 2(17), 210-214.

Vicente, S. \& Vicente, V. (2013). Maracatu rural: a magia do canavial. [Catálogo]. Ministério da Cultura: Brasil.

Vigotski, L. S. (1999). Psicologia da arte. São Paulo: Martins Fontes.

Vigotski, L. S. (2000). Manuscrito de 1929. Educação \& Sociedade, 21(71), 21-44.

Vigotski, L. S. (2001). Pensamento e linguagem. São Paulo: Martins Fontes.

Vigotski, L. S. (2007). A formação social da mente ( $7^{\mathrm{a}}$ ed). São Paulo: Martins Fontes.

Vigotski, L. S. (2009a). Imaginação e criação na infância. São Paulo: Ática.

Vigotski, L. S. (2009b). Sobre o problema da psicologia do trabalho criativo. (Trad. Delari Junior) Disponível em: <http://pt.scribd.com/doc/202596905/Vigotski-Sobre-oProblema-Da-Psicologia-Do-Trabalho-Criativo-Do-Ator-1932-Revisto\#scribd> Acessado em: fevereiro de 2014.

Vigotski, L. S. (2010). A educação estética (3 ${ }^{\text {a }}$ ed). In L. Vigotski. Psicologia pedagógica (321-363). São Paulo: Editora WMF.

Wallon, H. (2007) A evolução psicológica da criança. São Paulo: Martins Fontes. 
Wortmeyer, D., Silva, D. \& Branco, A. (2014). Explorando o território dos afetos a partir de Lev Semenovich Vigotski. Psicologia em Estudo, 19(2), 285-296.

Yanguello, M. (2006). Introdução (12 ed).. In M. Bakhtin. Marxismo e filosofia da linguagem (pp. 12-20). São Paulo: HUCITEC. 
ANEXOS 


\author{
ANEXO 1 \\ O Mito do Calango Voador e outras histórias do cerrado
}

\title{
A MITOLOGIA
}

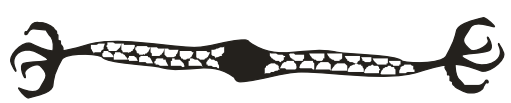

\section{PARTE 00}

\section{A MORTE DO NADA E O NASCIMENTO DE TUDO.}

O principio e o fim de tudo vem dela, da ETERNIDADE, a Senhora das Calmas.

Antes dela nada existia. Ela nasce do Nada e traz em sua alma a mudança. A Senhora da Calma tem três filhos e ai tudo começa.

O primeiro filho é o SOM, o Abissal. Um Deus inventivo, alegre e festeiro.

É com um canto do SOM que o universo é criado. É do seu cantar suave e poderoso, carregado de alegria e melancolia, que nasce todas as coisas. Das notas agudas do seu canto surge o SOL. Das notas graves surge a LUA. O SOM dança enquanto canta. Do brilhos dos olhos do SOM nascem as estrela. É deste canto que nasce a Terra. Do suor do Deus cantado e dançando passa a existir o MAR na Terra, dividindo com ela o mundo. De sua respiração no momento do canto nascem os VENTOS. E assim tudo se faz por meio dele, do SOM. Toda vez que ele inventa um novo barulho cria um ser para guardá-lo. Todo ser vivo emite um som ou guarda um.

Durante um longo período o mundo se dividiu entre Terra e Mar, até o momento em que a ETERNIDADE, a Senhora das Calmas, resolve descansar no mundo criado pelo SOM e aqui tem mais dois filhos: o TEMPO e o RIO.

O TEMPO é o Senhor dos Destinos. Para ele é dado o trabalho de amarrar os seres vivos neste mundo, carrega o poder de saber o momento preciso, necessário e propicio para a transformação de cada um. O Senhor que tudo dá e tudo tira. A ele cabe a tarefa de corta o fio que borda as almas a este mundo, as deixando partir para o encontro marcado com a sua mãe, a ETERNIDADE.

O terceiro filho é o RIO, o Senhor da Memória e dos Sentimentos. O Rio é alado, nasce voando, surgi primeiramente em forma de nuvens. É do firmamento. Derrama-se na terra, se aprofunda e vira cobra. Em forma de cobra se rasteja até o MAR, levando tudo que é lembrança, tristeza e pesar das criaturas do mundo. Vive num eterno vai-e-volta. 
Em seu passar pela Terra faz também florir o mundo. É o Senhor das Várias Coisas. Com o nascimento do Rio, a Terra que até então era só seca, transforma em Mata. O mundo ganha verde e todas as outras cores. Quando chega ao Mar, o Rio vira alado de novo, vira nuvem. Volta para o cerrado pelo chamado da Terra, das cigarras e pelo canto das pedras.

\section{Parte I - O dia que a Mata cantou Laiá.}

No tempo em que só existia o dia, no mundo várias coisas já viviam e todas tinham um ruído, um canto, uma fala.

E assim toda vez que aparecia mais um barulho novo, uma nova criatura tomava vida.

O que ainda não existia era à noite.

Foi neste tempo que LAIÁ surgiu. Filha de um cantar da MATA. A MATA filha do SOM, traz o axé de cantar para criar novos criaturas, assim como o seu pai.

Junto com LAIÁ nasce seu irmão, LUZBELO. Ele é formado pelo silêncio do canto da mata, pela pausa, pela inspiração da respiração. Por isso não tem forma. Por ter sido formado nos momentos em que a Mata puxava o ar para dentro do seu corpo enquanto cantava o canto de Laiá, ele pode penetrar qualquer outro ser, embaralhando os pensamentos de quem dorme, fazendo com que as criaturas sonhem entrando em seu mundo. LUZBELO é o dono dos sonhos (mas isso é outra história).

LAIÁ cresce entre as árvores e os bichos, se enfeita com as penas dos pássaros. Os pássaros do cerrado foram cantados e criados pelo canto de Laiá, como o beija-flor tesoura, o sábialaranjeira, tucano, bem-te-vi, sanhaço, as araras.

No tempo em que só existia o dia, LAIÁ dormia acalentada pelas Sombras.

As Sombras, no tempo em que só existia o dia, se arrastavam de um lado para o outro, sonhavam em subir pro céu assim como os pássaros.

De tanto sonhar com isso inventam de inventar uma grande ave.

Pegam as penas do cocar de LAIÁ enquanto ela dormia e fazem um pássaro assombroso em plena luz do dia. Foi assim que surgiu o GAVIÃO.

As sombras então se agarraram na ave, que voa com elas para o céu.

Mas quando as sombras chegam no céu, ele fica escuro. O dia escurece.

Os bichos se agitam. Quando as sombras chegam ao céu se faz surgir à noite.

Pela primeira vez na terra foi possível vê as Estrelas e a Lua.

Foi um susto, um encantamento, uns bichos começaram a uivar, outros se cagaram todinho, mas no fim todos se renderam ao luar.

Até hoje, todo dia as sombras sobem com o gavião e transformam o dia em noite e depois com o plumado descem transformando a noite em dia. 
Quem também fica encantada com a Lua é Laiá. Vendo que o Gavião sobe todo dia para o céu, Laiá tem a idéia de se agarrar ao gavião para subir para o firmamento com ele para tocar a Lua. No fim da tarde quando o Gavião ia alçar vôo, Laiá se agarra em seu pescoço. O gavião se agita e derruba Laiá, ainda assustado e sem entender o motivo do agarro, pica Laia bem no meio de suas pernas, fazendo ela sangrar. Laiá corre gritando assustada com o seu sangue, lá pra dentro da Mata. Por onde LAIÁ passa vai deixando pingos de sangue. As flores morrem de rir, zombando da cara de assustada de LAIÁ.

A Mata recebe LAIÁ. Ouve seu choro. Acha engraçada a travessura da menina, em suas raízes senti um sentimento de orgulho da audácia e da curiosidade da filha. Mas a picada do Gavião foi profunda, a Mata sabe que a picada irá marcar Laiá pelo resto da vida, canta para estancar o sangue, mas fala para a menina que ela sangrará todos os meses nos dias sem luar e que seu sangue vai está ligado para sempre com o Lua.

A Mata pede para Laiá se acalmar.

Para acalentar sua filha a Mata transforma os pingos de sangue de LAIÁ em Caliandras, cada pingo vira uma linda flor vermelha. Laiá ri-se inteira.

Para castigar as flores, que ficaram rindo do medo de LAIÁ, a Mata não deixa as águas da chuva tocarem seu corpo, fazendo assim com que todas as flores muxem, as únicas que ficaram inteiras foram as Calindras. Até hoje são elas que embelezam as Matas do Cerrado quando a seca acontece. Dizem que as flores sem aguentar a seca recorrem as Caliandras e pedem para ela falar com a Mata para deixar a chuva encostar de novo em seu corpo. A Caliandra intervém, mas em troca pede o segredo de todas as flores, seus feitiços.

O tempo passa e LAIÁ com ele cresce, em todos os sentidos e em formosura. Numa noite estrelada andando até os limites da mata, descobre o RIO. O RIO refletia o céu, e assim estava inteiramente coberto de estrelas, impressionantemente estrelado. LAIÁ se apaixona por ele.

Mas a MATA tem receio que LAIÁ se afogue. Então a Mata diz pra LAIÁ que o Rio que ela viu é na verdade uma grande cobra que rasteja pela Terra, que engole as criaturas e as deixa vivas dentro dele, transformando todas em peixe.

Diz para LAIÁ tomar cuidado com ele.

LAIÁ fica com medo, mas não pensa em outra coisa a não ser nele.

Mas numa noite enluarada, LUZBELO, o dono dos sonhos, visita LAIÁ e leva ela ao encontro do RIO. LAIÁ que dormia profundo, sonha com o Rio, banha-se, deleita-se em seu leito. O Rio recebe LAIÁ.

O céu estava lindo e iluminava ainda mais o sonho de LAIÁ, fazendo com que as estrela do Rio do seu sonho brilhassem ainda mais. LAIÁ acorda toda encharcada e de tão bonito que acha seu sonho, resolve pegá-lo e o coloca dentro de uma árvore.

Do sonho de LAIÁ é gerado SEU ESTRELO, que fica dentro da árvore até seu nascimento. No dia que Seu Estrelo nasceu, Laiá cantou e criou um pássaro, um Pica-Pau que com seu bico fez um buraco na barriga da árvore. Pelo buraco Laiá tirou seu filho de dentro do ventre daquela esverdeada criatura. Assim nasceu Seu Estrelo.

LAIÁ resolve levá-lo para o Rio, para que este pudesse vê seu filho. Mas ao se aproximar do Rio, LAIÁ é engolida por ele, é levada por suas águas. Seu Estrelo se salva e a Mata o protege. 
As criaturas da Mata dizem que LAIÁ virou uma sereia, que o Rio apaixonado por ela não teve coragem de transformá-la por inteira em peixe, fazendo isso só em uma metade, da cintura para baixo. As criaturas dizem também que Laiá de vez em quando aparece cantando, imitando o canto da Mata que vez com que ela surgisse. Um canto lindo cheio de estrelas.

\section{UMA SINGELA HISTÓRIA DE AMOR DE UM TEMPO INFELIZ Ou}

\section{O TEMPO, o RIO e o coração de LAIÁ, a filha da Mata.}

O Rio e o Tempo são irmãos, filhos da ETERNIDADE. Apesar de ter nascido primeiro que o Rio, o Tempo é mais novo que ele. O Tempo traz em sua alma a mocidade, a novidade, é um ser presepeiro. O Rio carrega a profundidade do mundo, em comparação com o Tempo é mais sisudo. O Tempo adorava brincar de ir pra frente e pra trás. Foi o Tempo, o primeiro a conhecer Laiá e se apaixona por ela. Viu Laiá crescer, segurando sua ansiedade de já torná-la moça. Sem querer ver o seu futuro com Laiá para viver o presente, o Tempo não ficou sabendo o que Ihe esperava. Laiá crescida se apaixona não por ele, mas por seu irmão, o Rio. É com o Rio que Laiá vai sonhar, é com ele que vai ter seu filho, é com ele que Laía vai ficar e passar todo o seu tempo. Assim o Tempo, que vinha e voltava resolve seguir em frente para nunca mais retroceder. Não olha mais para trás. Por mais que quisesse parar ou voltar, sabia que Laiá não ficaria com ele, não era o seu destino. Entristecido o Tempo chora rios de lágrimas, isso é outra prova que o Tempo e o Rio são irmãos, só eles, a água e o tempo que podem lavar e apaziguar as tristezas do mundo.

\section{Parte II - O NASCIMENTO DO CALANGO VOADOR OU O ALADO DO CERRADO}

No tempo em que o dia e a noite já existiam, conta-se que de tanto se lamberem e de tanto se abraçarem, a Terra e o Mar ficam apaixonados. Ele todo se encanta com a firmeza da Terra e ela fica seduzida pela profunda fluidez de seu ser. E no vai-e-vem das águas temperada do amor, hora fria e hora quente, a Terra resolve se entregar ao Mar.

Porém, firme no firmamento, havia o Sol, que há tempos desejava a Terra. $\mathrm{O}$ astro rei, ao saber de tudo, enciúma-se e conta o caso para a Lua. Essa morria de encantos pelo Mar. Então, Lua e Sol combinam de enganar a Terra.

Na noite marcada pela Terra para se entregar ao Mar, o Sol, antes de se esconder, diz pra Terra que a Lua está grávida do Mar. A Terra não acredita e espera a Lua aparecer. A Lua aparece no distante horizonte, esplendorosa, linda, imensa, branca, redonda e brilhante, tão cheia que era impossível não acreditar que ela estava realmente embuchada.

A Terra irada, não se abre para receber o seu amado. Mas o Mar, ignorando a armação arquitetada pelos astros, avança impetuoso, trazendo do seu corpo agitado uma onda gigantesca, vinda do mais distante oceano, pronta para aquele ato. Desiludida, a Terra se fecha, rochedos começam a surgir, emergindo da água, e a onda que avançava se quebra por inteira, derrubando uma embarcação que na beirinha do mar descansava. 
Um casal, que no barco estava (Joana das Conchas e Pedro das Beiras), é lançado impetuosamente ao mar. A imensa espuma daquela onda quebrada se espalha pela enseada como um verdadeiro gozo, e entra de todas as maneiras em Joana, a mulher de Pedro. Pedro era fazedor de barcos e tão bom nos barcos que fazia, que quase todos aqueles que resolviam atravessar o Mar encomendavam um barco feito por ele. Pedro era tão bom e confiava tanto nos seus barcos, que nunca aprendera a nadar. Por isso, depois da inesperada investida da gigantesca onda, seu barco soçobrou e Pedro afogou-se. Joana conseguiu se salvar, mas sem perceber, trouxe dentro de seu ser o gozo do Mar, e assim, acabou carregando um filho deste em seu ventre.

Com uma tristeza profunda, morrendo de raiva e enfraquecida, a Terra deixa-se enganar mais uma vez pelo Sol. Ele consegue convencê-la de que para se vingar, a Terra deveria se entregar para ele. A Terra concorda e assim que o dia raiou, deixou os raios do Sol penetrarem por todo o seu corpo, iluminado-a e aquecendo-a inteira.

Depois de uma semana, quando a Lua apareceu toda minguante, a Terra viu que fora enganada, mas tarde já era, pois estava grávida, emprenhada do Sol, já esperava um filho dele.

Com vergonha do Mar e vendo que fora enganada, a Terra resolve ter seu filho em outras paragens, bem longe dali. Deu à luz no Planalto Central, no Reino da Mata, e seu rebento é logo transformado em um Calango, para que assim fosse difícil de ser encontrado. No Cerrado e dessa maneira, nasce o filho do Sol e da Terra. O Mar só ficou sabendo que a Terra ficou grávida do Sol quando a Lua contou, assim que o Calango nasceu.

Joana das Conchas também tem seu filho, este cresce junto ao Mar e vira um hábil Pescador. Pega tudo que quer, até o mais arredio dos que nadam profundo, mesmo misteriosas e encantadoras criaturas aquáticas não se Ihe escapavam. O Mar fica desconfiado com tanto destemor, pensa que aquele menino só podia ser um dos filhos seus. Encantado com o menino Pescador, logo adota o garoto, já que o seu filho com a Terra não vingou.

Um dia quando o Pescador já adulto voltava de uma pescada, encontrou na beira do Mar, mareada e majestosa, a bela Mariasia.

Quando o Pescador viu Mariasia, foi amor à primeira vista. E de tanto amor e de tanto amar, decidiram se casar. E assim, preparando a cerimônia, o tempo, que nunca espera, passou.

Perto do casamento, o Pescador, que já havia dado uma verdadeira constelação de estrelas do mar a Mariasia, pediu então ao Mar a sua Lua, sempre vista por ele em noites de luar. Esse seria o presente de casamento perfeito para Mariasia, assim achava o Pescador. O que 0 Pescador não sabia é que aquela Lua que ele via dentro do mar não era a verdadeira, mas apenas seu reflexo. A Lua pertencia ao céu, por isso toda vez que ele mergulhava para pegar a Lua, essa se desfazia. O Mar, ainda cheio de raiva pela traição da Terra, resolve enganar seu filho. Ele diz para o Pescador que para pegar a Lua que desejava, o rapaz tinha que matar um animal sagrado que vivia distante dali, no cerrado. O Mar disse que este animal sagrado é que tinha aprisionado a brilhante lua dentro Mar. O Pescador, sem querer mais explicações e cheio de amor por Mariasia, aceita a missão de ir embora para caçar o Calango.

Voltando de sua pescaria, o filho do mar avisa a Mariasia que antes de se casar queria dar-lhe um magnífico presente e que seria preciso viajar para esse seu desejo realizar. Mariasia sente por meio dos ventos que algo de errado está pra chegar, mas vendo os olhos de mar do pescador resolve deixar o seu amado buscar o tal presente. 
O Mar então, faz crescer de si uma enorme onda. Uma carruagem com cavalos feitos de água do mar. É nessa carruagem que o Pescador sobe as águas dos rios, invertendo o curso natural das águas. A onda do mar sobe pelo rio até sua nascente.

Mas antes de partir, recebeu do Mar um arpão tão poderoso que qualquer mortal comum perderia a vida ao ser tocado por ele.

Ao chegar no lugar indicado pelo Mar, a carruagem de águas salgadas se desfaz e o Pescador chega enfim ao cerrado.

Mariasia, que sempre ficava na beira do mar à espera do Pescador, começa a perceber os rumos dos ventos. Com o Pescador distante, se vê triste e chorosa, pedindo para o lamentoso coração se aquietar. Então, por meio da amizade que conquistou com o vento, começou a mandar mensagens de amor para o Pescador. Devido ao longo percurso, o vento sabendo que palavras não percorrem tamanhas distâncias e com pena de Mariasia, faz com que as mensagens se transformem em borboletas.

Dessa forma, as borboletas chegam até o Pescador, dançam em sua volta e depois procuram as flores do Reino da Mata para descansar. O Pescador, encantado com a leveza daquelas borboletas, vai atrás delas.

Entrando no Reino das Flores, o Pescador se depara com a Caliandra, flor mais linda que existe no Cerrado. Lembra-se de Mariasia e pega a flor. Mas de repente, vê um Gavião se aproximando, que avança em vôo para cima do Pescador e diz que aquela flor é dele e ninguém tem o direto de colhê-la.

O Pescador se protege, cai no chão e pega seu arpão para investir contra a ave de rapina. Mas depois de pensar um pouco, lembra-se de sua missão, então pede pro Gavião se acalmar e com o arpão na mão, fala que só devolve a flor se o Gavião falar onde o Calango costuma aparecer.

O Gavião, com medo do arpão e querendo a Caliandra, diz então onde o Calango se maloca. O Pescador agradecido devolve carinhosamente a Caliandra e vai ao lugar referido.

Depois de muito esperar, o Pescador vê o Calango chegando. O bicho pára e ofegante descansa sob o Sol. A Terra sente o pior e avisa ao Sol que observe aquela criatura.

Bem devagar o Pescador se aproxima, pega o seu arpão e prepara-se para lançá-lo. Nunca havia errado um alvo, nem muito menos deixado algum bicho escapar, tão astuto ele era. Mas no momento do golpe, o Sol manda um brilho forte, um pedaço de seu corpo-fogo, para o céuda-boca do Calango. Sentindo em sua boca o poder do fogo, o filho da Terra estira sua língua. O brilho do Sol reluz da boca do Calango e cega o Pescador por um instante, ofuscando-lhe as vistas. Mesmo assim o Pescador lança o seu radiante arpão.

O arpão atinge de raspão o dorso do Calango, e atravessa o Rio, ferindo as suas águas. $O$ Pescador corre e mergulha no Rio, pega seu arpão afim de ainda alcançar o Calango. Mas quando ele toca o seu arpão sente o mundo tremer. O Rio enfurecido e ferido pela arma do caçador, faz surgir das suas águas um imenso Elefante com uma Tromba D'Água gigantesca. O Elefante $\mathbf{D}$ 'água com suas patas e sua tromba d'água vai destruindo tudo o que há em seu caminho. É aí que a Terra, sentindo que o seu filho não pode se salvar e que vai ser arrastado pelas águas do Rio enraivecido, pede pro Ar salvar ao seu filho. O Ar assim dá asas ao Calango, e este consegue voar, livrando-se da poderosa Tromba D'Água do Elefante do Rio. Corre um boato entre os bichos do Cerrado, que as asas do Calango foram tiradas do Gavião, aquele que falou para o Pescador onde o Calango aparecia.

O Elefante, com pisadas pesadas, atropela o Pescador que de tanta dor desmaia. Acorda embaixo das patas, descendo pelo leito formado de pedras. O filho do Mar dá um giro e 
rodopia. O Elefante puxa-o pra baixo, o Pescador dá um pinote e nas costas do enorme bicho ele sobe.

Nas costas do Elefante ele levanta o seu arpão, que fere tudo o que por ele é tocado. Mas o Elefante novamente puxa o Pescador para o fundo e os dois vão se embolando e descendo leito abaixo. O leito vai se abrindo e só para perto do Mar.

E até hoje, toda vez que o Mar se enche, tenta jogar o Pescador pra cá, mas depois que perde a força e se esvazia, o Rio o manda de volta pra lá, numa disputa de força sem fim.

Falam na Mata, que quando o Calango Voador resolve matar sua sede e esfriar sua língua, que fica seca e quente por causa do pedaço do sol que traz em sua boca, um período de seca acontece e castiga o cerrado e as águas diminuem de volume. Quando enfim o Calango mata sua sede e pára de beber toda a água do rio, as águas sobem novamente, enchendo as corredeiras e as cachoeiras.

E foi assim, de amor e desamor, de temor e destemor, que surgiu o Calango Voador, reverenciado rebento, filho da Terra e do Sol, afilhado do Ar, lendária criatura, mito dos ritos de cá.

\section{Parte III - A MATA E A TRISTE CRIATURA COMEDORA DE HOMENS}

Na TERRA DE ALÉM-MAR surgiram homens sem cor que nem cantavam e nem dançavam. Estes homens foram frutos de um cantar cheio de arrogância e soberba por parte da natureza, que pensaram em fazer uma criatura mais perfeita que aquela criada pela Mata deste lado do Mar.

E foi assim, logo que chegou as noticias da criação de Laiá lá no outro lado das águas salgadas, de toda a sua beleza, a Terra de Além-Mar decidiu também criar uma criatura parecida com ela, mas ainda mais encantadora. E assim num cantar bem grave cheio de beleza, carregado de encanto, inveja e tristeza, surgiu os primeiros homens sem cor da Terra de Além-Mar. E por ter vindo de um canto com a intenção de ser superior a outro cantar, estes homens se sentiam mais elevados que qualquer outra coisa que havia, mais poderosos inclusive que a própria natureza.

Até um certo momento, viviam em paz com a natureza até que começaram a se multiplicar sem parar, desafiando a própria Terra.

De tanto se multiplicar os homens sem cor viraram uma praga para a Terra de Além-Mar. Era preciso destruir aquela praga antes que os homens se multiplicassem ainda mais. A natureza tentou destruir os homens sem cor com suas forças naturais, mas os homens que nem cantavam e nem dançavam conseguiram resistir.

A natureza de lá então decidiu criar um homem que pudesse derrotar os homens que ali teimavam em existir. Mais um canto foi cantado pela natureza e assim surgiu o homem que acabaria com os outros homens. Este homem, como os outros nem cantava e nem dançava, mas nasceu com o poder de construir coisas. Com a ajuda da natureza foi construindo de tudo, abrigos, ferramentas, armas e máquinas, até chegar a maior de suas construções, aquela que 
ia engolir todos os homens. Foi para esta construção que este homem surgiu, foi para isto que ele foi criado pela natureza, para construir a GRANDE COISA.

A GRANDE COISA começou bem simples, mas foi ficando cada vez mais complicada. Dentro dela havia um fogo que comia madeira, a COISA soltava fumaça. Começou parecida com uma casa, que tinha grande boca e olhos de fogo vermelho. A COISA se arrastava com seus pés de roda. Logo já vinha com outra casa grudada e mais uma. A COISA começou a engolir os homens e conforme engolia, ia ficando cada vez maior. O que era parecida com um bicho-casa rapidamente já havia se transformado em uma cidade-animal.

A CIDADE assim surgiu e como um grande monstro foi engolindo cada vez mais homens, todos que via. Os homens que eram engolidos viravam escravos do Grande Comandante, daquele que gerou a COISA.

A GRANDE COISA ficou tão grande que a natureza ficou com medo e tentou parar seu crescimento. Vendo o mal que tinha feito, a natureza tentou falar com o homem que ela criou para engolir os homens. O Grande Comandante até que tentou parar a criatura, mas os outros homens alimentados de ambição, os mesmos que haviam sido engolidos pala GRANDE COISA, conseguiram tomar o poder do Grande Comandante. Comandando a COISA sentiam-se os donos do mundo. A natureza então tentou parar aquilo à força, mas de nada adiantou. Ela já estava enorme e ao mesmo tempo que ia engolindo outros homens ia também destruindo a natureza.

A COISA já tinha crescido tanto que começou a ocupar toda a TERRA DE ALÉM-MAR. Já estava tão grande que para chegar de um lugar para o outro dentro dela, os homens começaram a construir estradas. Vários homens que tinham sido engolidos pela COISA como escravos, agora já mandavam nos outros homens. Eram escolhidos pelos Comandantes da GRANDE COISA para controlar os escravos e as suas revoltas. Em troca ganhavam lugar privilegiado dentro da criatura.

A COISA vai ocupando espaços, destruindo matas, poluindo os rios, devastando toda a Terra Além-Mar. Ela ganha força, transforma a sua natureza. Ganha novas formas, novas ferramentas, endurece, ganha cheiro, fumaça, luz, ganha barulhos. Cada barulho surgia tentava ser mais alto e barulhento que os outros.

O tempo foi passando e os Comandantes que achavam que nunca morreriam, morreram. Mas deixaram seus sucessores. $E$ todos eles conduziam a COISA do mesmo jeito que aqueles que se foram. Na verdade ninguém mais nem sabia se a COISA era mesmo controlado por alguém ou se já fazia as coisas por conta própria. Mas sempre tinha um Grande Comandante ou pelo menos alguém que dizia que comandava a GRANDE COISA.

Já havia muitos homens e mulheres dentro da COISA. Muitos deles já haviam nascido dentro dela e nem sabia como era vida fora da criatura, achavam que era impossível viver fora da estrutura dela. Alguns conseguiam sair da COISA, ela já estava tão grande que existiam algumas passagens, buracos para fora do seu corpo. Muitos homens saiam e voltavam trazendo plantas, semente de árvores, frutos, bichos e pedaços da mata para dentro. Outros que conseguiam achar estes buracos saiam para sempre. 
O fato é que na TERRA DE ALÉM-MAR já não existia mais tanta natureza fora da COISA. Ela havia destruído quase tudo. Não se tinha muito para onde correr. E assim, os homens foram se adaptando a viver dentro da GRANDE COISA, da grande CIDADE. Alguns homens lá de dentro ainda tentaram mudar o destino da enorme criatura, mas eram sempre impedidos pelos donos do poder. Como também as rebeliões internas puxadas pelos escravos, que acabavam sempre abafadas.

Depois de conquistar toda a TERRA DE ALÉM-MAR, a Coisa chega então à praia, ao Mar. O Mar e suas Criaturas sem entender direito o que era aquela coisa preparam-se para enfrentá-la. A guerra começou e até hoje ainda não parou. Os comandantes da COISA inventaram máquinas que flutuavam pelo mar. Cheios de coragens, os homens saiam da COISA e invadiam as águas salgadas. De tanto investirem contra o mar, os homens e a COISA atravessaram o oceano e chegaram enfim a nossa terra.

Desembarcaram em terras alheias sem nenhuma cerimônia. E como fizeram nas Terras AlémMar chegaram com a COISA engolindo os homens que aqui existiam e destruindo tudo.

A GRANDE COISA foi crescendo, devastando e desmatando. A coisa vinha abrindo caminho pela floresta, rasgando a Terra, entrando à força em suas entranhas. Do corpo da GRANDE COISA saiam duras máquinas, armas, luzes, fogo. Não parava de crescer, era um monstro em evolução. E assim começa a se arrastar direto para o cerrado.

No cerrado, Seu Estrelo foi avisado e rapidamente reuniu todo seu povo. Chamou também o Calango Voador, convocou a Mata e seus filhos e filhas. Homens de tudo que é de lado para se juntar na batalha contra a GRANDE COISA que se aproximava. Homens, filhos da Terra de cá, que diferente dos filhos da Terra de Além-Mar, cantavam e dançavam e mantinham com a Mata uma profunda ligação.

A GRANDE COISA por fim chegou ao cerrado, com seus olhos vermelhos, cuspindo fogo, soltando fumaça. A batalha tem seu inicio. Os primeiros a enfrentar a GRANDE COISA são os filhos da Mata, os homens daqui, os Jê, que com seus arcos, flechas e uma coragem espantosa tentam evitar a destruição de tudo. A Batalha é longa e apesar de toda a bravura dos Jê a GRANDE COISA ganha espaço.

Seu Estrelo manda chamar Luzbelo, o irmão de Laia, o dono dos sonhos. Fala para Luzbelo entrar na Coisa, penetrar nos sonhos dos homens de lá de dentro. Mostrar para eles que o que estão fazendo vai acabar com todos os seres do mundo. Fala pra Luzbelo oferecer aos homens engolidos novos sonhos. Mas o que Seu Estrelo não sabe é que são poucos os homens engolidos que ainda podem e sabem sonhar.

Os que ainda conseguem sonhar, recebe Luzbelo em suas cabeças e fogem da GRANDE COISA. Massacrados lá dentro do monstro, sem direito a suas vidas, decidiram fugir e lutar junto com aqueles que estavam do lado de fora contra a ENORME CRIATURA. Alguns destes homens fugidos tinham entendido, ainda dentro da COISA, que com toda aquela destruição o mundo estaria condenado. Era preciso atrelar todas as forças. Cheios de esperanças, os homens constroem uma cidade para se alojar e em homenagem ao ser sagrado do lado de cá, o Calango Voador, dão a ela asas. 
Seu Estrelo, os homens fugidos, A Mata e seus seres preparam para mais uma ofensiva da triste criatura. Dançam e cantam chamando a força da Terra. Cada ser traz sua falange. $O$ Calango Voador comandaria os seres da Mata. Todos estavam prontos para a Batalha.

A Mata lançou um canto. Os homens tocaram e dançaram pros seus santos. Seu Estrelo jogou seus feitiços, o Calango seus raios de sol. Cada qual ser da mata deu sua investida.

E assim a COISA pela primeira vez em sua vida parou. Estava perdida com aquela tamanha ofensiva. Estava encantada, agora com os cantos da Mata. Atingida em sua alma. Sua estrutura tremia, como se o canto entrasse em cada uma de suas peças, em cada um de seus parafusos, parecia que ia se desmontar. Seus olhos de luz piscavam. A bicha foi se desestruturando, caindo em pedaços, abrindo espaços dentro de si. Com isto a Mata, o Ar, o Sol foram logo entrando. De repente a GRANDE COISA se viu bonita, enfeitada de flores e árvores, de canto e encanto. Até o Calando Voando por dentro da COISA voou. Os trabalhadores, os escravos, os loucos e operários lá de dentro, gritaram pela liberdade. Rapidamente se juntaram e tentaram tirar o poder daqueles que os maltratavam. Parecia que a GRANDE COISA estava domada, o mundo depois de tanto tempo se enxergou em harmonia.

Mas foi ai que tudo desandou. Os Comandantes da GRANDE COISA logo se reorganizaram, com seus exércitos e com suas máquinas de guerra, de barulho e de fumaça, acabaram com revolta criada e fizeram novamente a COISA se mexer. Sem escutar o canto da natureza, cega em meio a tanta fumaça, controlada a força e a lapada, a COISA meio sem graça deu seu contragolpe. Foi uma luta desigual, os Comandantes voltaram lutando pesado, matando, aprisionando todos que se colocassem em seus caminhos. Calaram a revolta, mataram e exilaram homens, mandado os traidores para Terras de Além-Mar.

A batalha foi suada, de um lado a grande máquina, do outro a força da mata.

No meio de tanto barulho e tanta fumaça, o Calango Voador sumiu.

Alguns dizem que ele morreu. Alguns que ele foi pego depois de cair de cansaço, sufocado pelas nuvens de fumaça que cobriam até o sol e que está preso engaiolado dentro da GRANDE COISA. Outros dizem que ele voou até seu pai, o Sol, para de novo se esquentar. Tem mais uns que falam que ele se escondeu dentro do cerrado pra juntar suas forças e que a qualquer momento vai voltar.

Seu Estrelo sentiu que num confronto direto não teria ganhadores, os dois lados perderiam. A GRANDE COISA acabaria com a Mata e com o fim da Mata todos os homens também se destruiriam inclusive os que estavam dentro da GRANDE COISA. A luta era mais sutil. Sabia também que o Calango Voador tinha que está ao seu lado, não tinha chance sem o filho da Terra e do Sol. Seu Estrelo, os homens fugidos e a Mata recuaram.

A batalha foi vencida pela GRANDE COISA, mas a guerra ainda não.

Seu Estrelo entendeu o que era preciso. Não adiantava ficar de um lado e a GRANDE COISA do outro. Percebeu que só levando a força da natureza lá pra dentro da COISA era possível tentar 
domar aquela triste criatura. Também tinha que achar o Calango. Foi aí, que Seu Estrelo juntou de novo seu povo e contou seu novo plano. Disse que era preciso os homens e as criaturas da mata se dividirem. Uns ficariam do lado de fora da COISA, outros entrariam. Os homens engolidos sempre que pudessem chamariam a força da Mata para dentro da criatura.

Com isso Seu Estrelo se afastou e cavou um buraco com as mãos. Um buraco do tamanho do seu corpo. Seu Estrelo entrou no buraco e se plantou. Nasceu do buraco uma árvore imensa, no lugar dos frutos cresceu estrelas. Os homens que iram entrar na COISA comeram as estrelas e ficaram alimentados do corpo estrelado de Seu Estrelo.

Alimentados deixaram a COISA os engolir.

Hoje, estes homens e mulheres dançam e cantam pra Seu Estrelo, trazendo para perto deles e para dentro da COISA a força da natureza. Recebem, hora dentro da COISA hora fora, Seu Estrelo e sua Falange. Contam e transmitem em suas brincadeiras, para seus filhos e seu povo, a história do Calango Voador. Alimentados de Seu Estrelo, nutrem-se da esperança de que um dia o Calango novamente aparecerá e junto com outros homens encantarão novamente a GRANDE COISA, dando fim a guerra entre a Triste Criatura Comedora de Homens e a Natureza. 


\section{ANEXO 2}

\section{PARECER DO COMITÊ DE ÉTICA}

INSTITUTO DE CIÊNCIAS HUMANAS 


\section{INSTITUTO DE CIENCIAS HUMANAS / UNIVERSIDADE DE BRASÍLIA / CAMPUS}

\section{PARECER CONSUBSTANCIADO DO CEP}

\section{DADOS DO PROJETO DE PESQUISA}

Título da Pesquisa: A Constituição dos Processos Criativos em Brincantes da Cultura Popular Pesquisador: Andressa Moreira

Área Temática:

Versão: 1

CAAE: 39108714.5 .0000 .5540

Instituição Proponente: Instituto de Ciências Humanas

Patrocinador Principal: Financiamento Próprio

\section{DADOS DO PARECER}

Número do Parecer: 912.132

Data da Relatoria: 11/12/2014

Apresentação do Projeto:

Apresento, neste projeto, uma proposta de pesquisa que tem como objetivo geral investigar a constituição dos processos criativos e das atividades criadoras no contexto artístico da cultura popular brasileira. Dentro desse universo complexo e amplo, abordo a dimensão especifica do brincar adulto, enquanto uma profissão denominada de brincante. Para a compreensão desse brincar diferenciado do brincar infantil, investigo os aspectos psicológicos que possibilitam aos seres humanos a capacidade singular de expressão e criação artistica, partindo dos estudos sobre imaginação e catarse, fundamentados pela perspectiva históricocultural. Abordo, em seguida, o caráter mais particular da arte popular e a sua dimensão estética composta pelas categorias bakhtinianas de subversão, dualidade e corpo grotesco. Como pesquisa de campo, proponho entrevistas narrativas com alguns/algumas brincantes do grupo Seu Estrelo e o Fuá do Terreiro, localizado em Brasilia, Distrito Federal. Já as construçōes e reflexões sobre os dados obtidos no campo são fundamentadas pela análise do discurso, considerando que um discurso é também um objeto sócioideológico,subjetivo e coletivo.

Objetivo da Pesquisa:

Primário: O objetivo geral da pesquisa é investigar a constituição dos processos criativos em brincantes, com foco na construção de significados e sentidos do brincar na cultura e arte popular.

Endereço: CAMPUS UNIVERSITARIO DARCY RIBEIRO - ICC ¿ ALA NORTE ¿ MEZANINO \& SALA B1 ; 606 (MINHOCÃO

Bairro: ASA NORTE CEP: $70.910-900$

UF: DF Municipio: BRASIIA

Telefone: (61)3307-2760
E-mail: ihd@unb.br 


\section{INSTITUTO DE CIENCIAS HUMANAS / UNIVERSIDADE DE BRASÍLIA / CAMPUS}

Continuaçāo do Parecer. 912.132

Secundário: Analisar as narrativas dos/as brincantes sobre e durante os seus processos criativos; Investigar a relação entre resistência e atuação politica nas expressões dos/as brincantes;- Pesquisar a relação entre tradição e inovação na constituição dos processos criativos dos/as brincantes;- Investigar a articulação entre histórias de vida e processos criativos na constituição dos/as brincantes.

\section{Avaliaçăo dos Riscos e Beneficios:}

Especificidades de uma Pesquisa em Psicologia e Arte: Por se tratar de uma pesquisa que se estabelece no diálogo entre a psicologia e a arte, e

que investiga questões que não colocam em risco a integridade fisica, mental e moral dos/as participantes, optamos pela identificação dos/as

mesmos/as com suas prévias autorizações (em anexos). Conforme elucidamos na fundamentação teórica (ver projeto), a autoria na dimensão da

cultura popular é um aspecto relevante e o fato de omitir essa dimensão na pesquisa seria uma incongruência entre teoria e prática. Outro fator é

que, à medida que investigamos os processos criativos dos/as brincantes (que envolvem as suas manifestaçōes concretas, como já elucidamos) e

os descrevemos, explicitamos características que são próprias do grupo, fato que consequentemente o tornaria reconhecivel.

\section{Comentários e Considerações sobre a Pesquisa:}

não há.

Considerações sobre os Termos de apresentação obrigatória:

apresenta todos os termos

Recomendações:

não há

Conclusões ou Pendências e Lista de Inadequações:

não há

Situação do Parecer:

Aprovado

Endereço: CAMPUS UNIVERSITARIO DARCY RIBEIRO - ICC ¿ALA NORTE ¿ MEZANINO ¿ SALAB1 ¿ 606 (MINHOCÃO Bairro: ASA NORTE CEP: $70.910-900$ 


\section{INSTITUTO DE CIENCIAS \\ HUMANAS / UNIVERSIDADE \\ DE BRASÍLIA / CAMPUS}

Continuação do Parecer: 912.132

Necessita Apreciação da CONEP:

Não

Considerações Finais a critério do CEP:

BRASILIA, 12 de Dezembro de 2014

Assinado por:

Livia Barbosa

(Coordenador)

Endereço: CAMPUS UNIVERSITARIO DARCY RIBEIRO - ICC \& ALA NORTE \& MEZANINO ; SALA B1 ; 606 (MINHOCÃO

Bairro: ASA NORTE

CEP: $70.910-900$

UF: DF Municipio: BRASILIA

Telefone: (61)3307-2760

E-mail: ind@unb.br 